
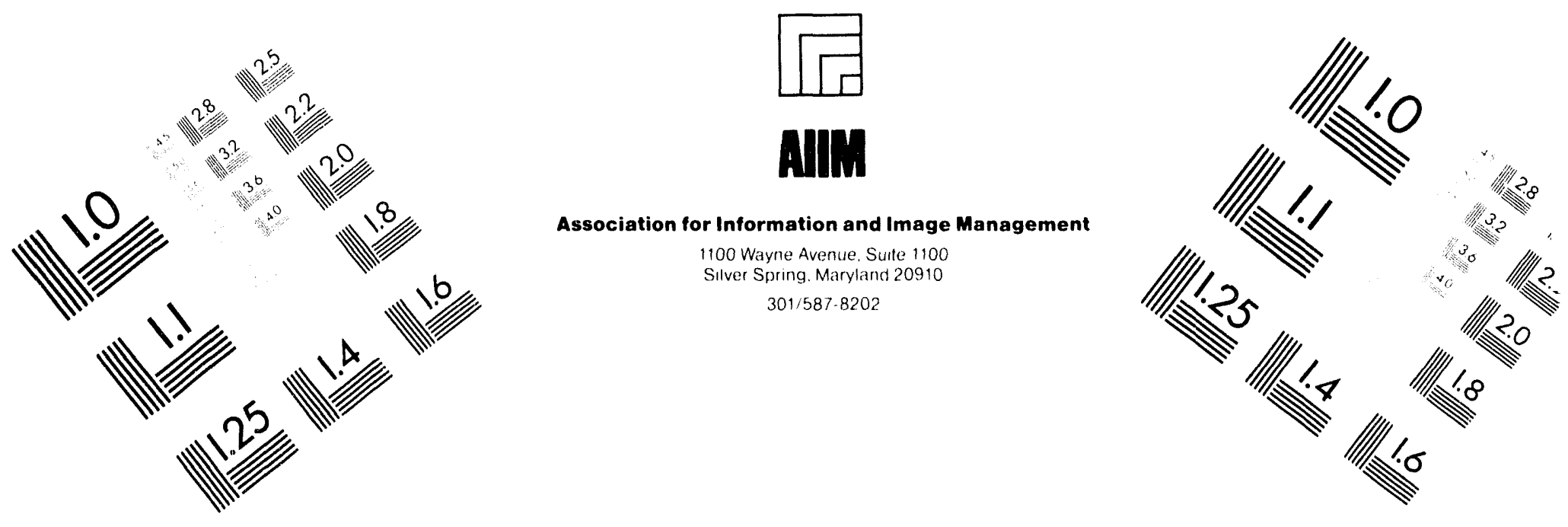

\title{
Centimeter
}

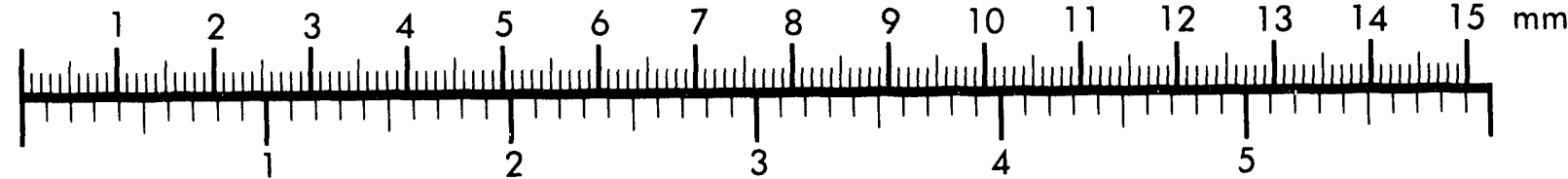

Inches
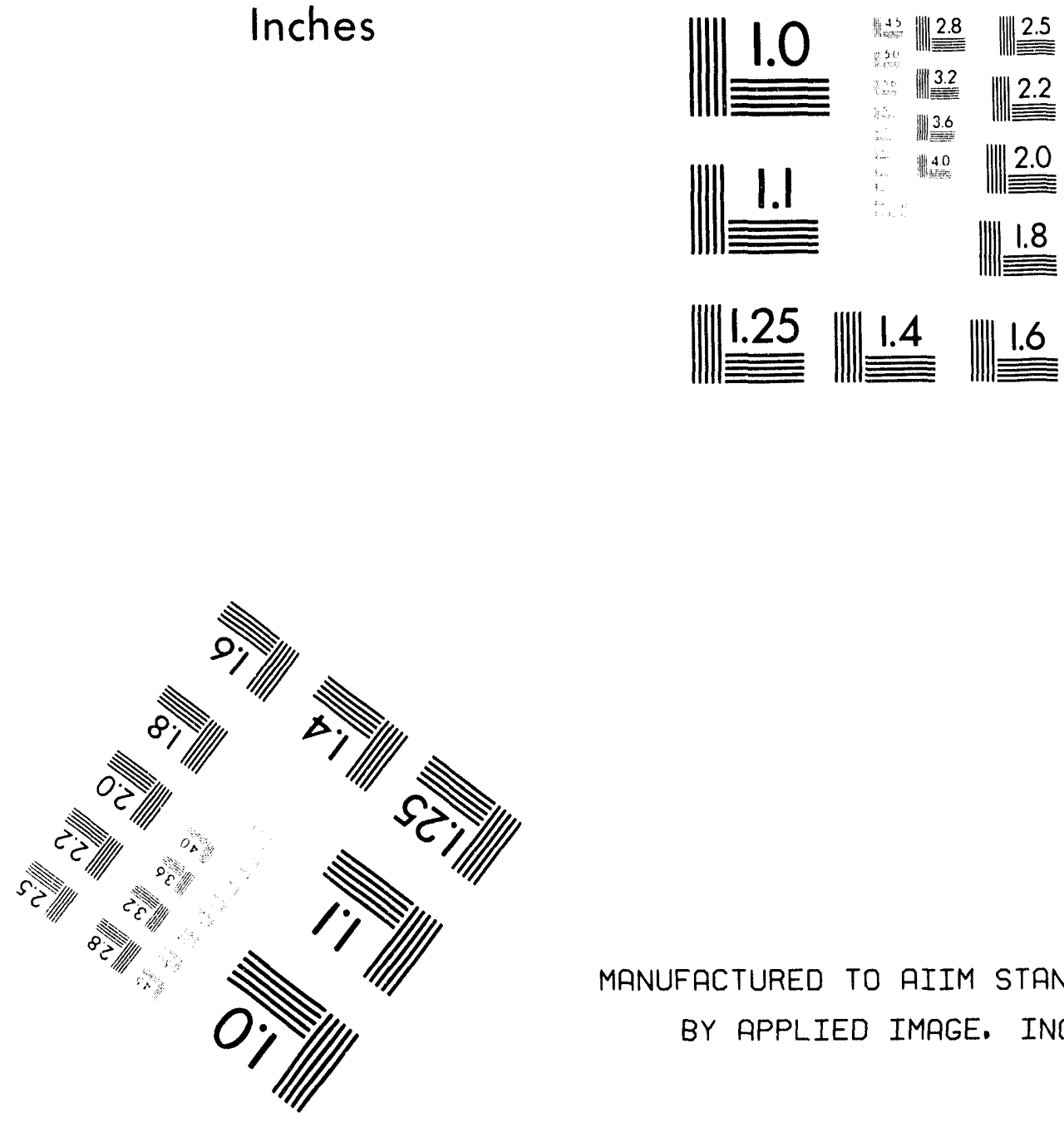

MANUFACTURED TO AIIM STANDARDS

BY APPLIED IMAGE. INC.

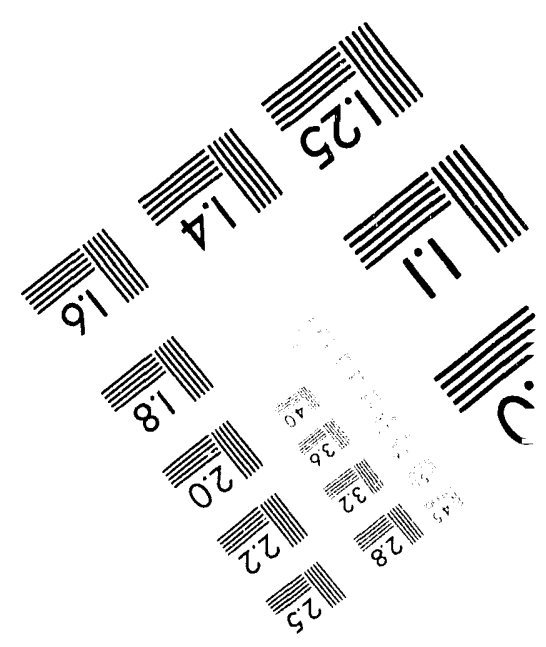



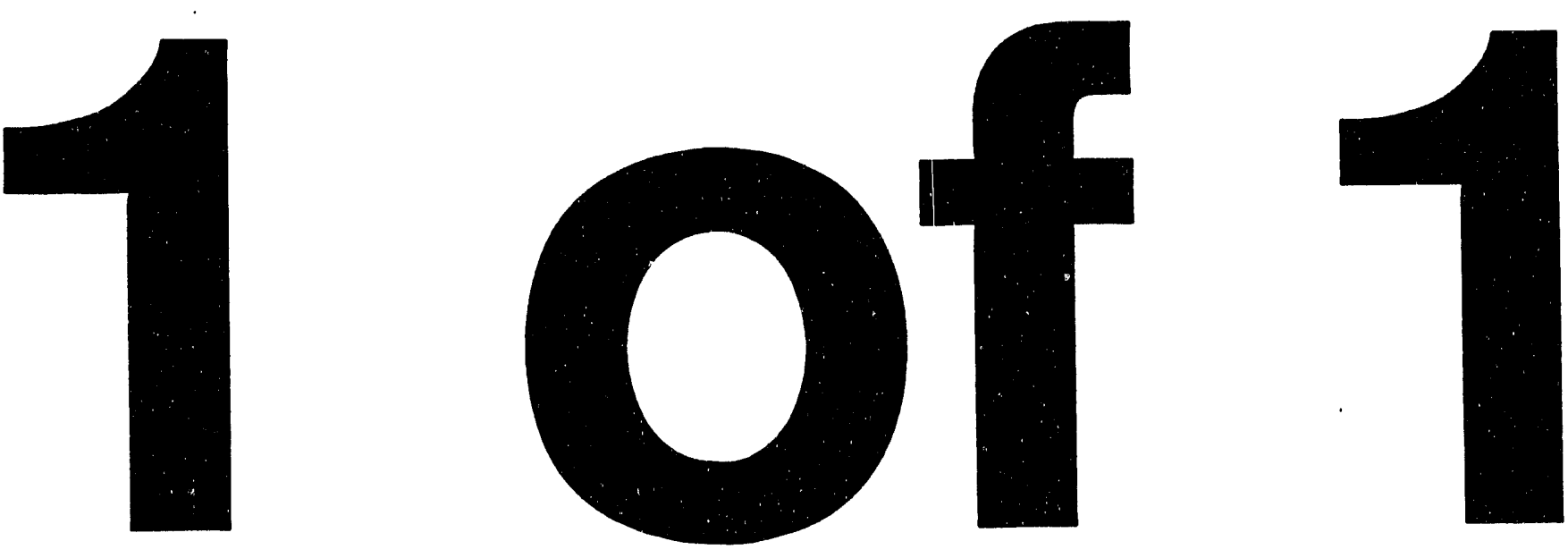
WSKC-TR-94-166

Publication Date: May 1994

\section{Annual Radioactive Waste Tank Inspection Program - $1993^{(\mathrm{U})}$}

Westinghouse Savannah River Company

Savannah River Site

Aiken, SC 19808

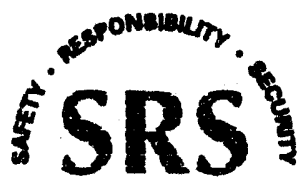

Prepared for the U.S. Department of Energy under Contract NO. DE-AC09-89SR1 8035 


\section{Disclaimer}

This report was prepared as an account of work sponsored by an agency of the United States Government. Neither the United States Government nor any agency thereof, nor any of their employees, makes any warranty, express or implied, or assumes any legal liability or responsibility for the accuracy, completeness, or usefulness of any information apparatus, produce, or process disclosed, or represents that its use would not infringe privately owned rights. Reference herein to any specific commercial product, process, or senvice by trade name, trademark, manufacturer, or otherwise does not necessarily constitute or imply its endorsement, recommendation, or favoring by the United States Government or any agency thereof. The views and opinions of authors expressed herein do not necessarily state or reflect those of the United States Government or any agency thereof.

Published in cooperation with WSRC Management Services

Department Publications Group.

Technical Editor: Charlie Tope 
WSRC-TR-94-166

Publication Date: May 1994

\section{Annual Radioactive Waste Tank Inspection Program - $1993^{(U)}$}

F. G. McNatt, Sr.
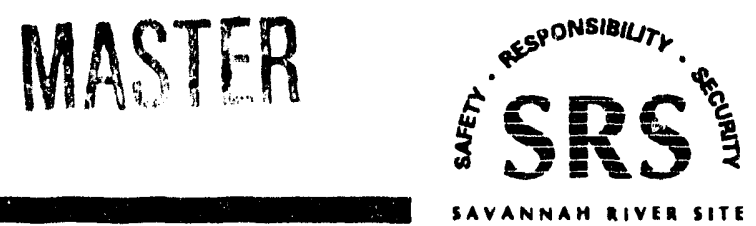

Prepared for the U.S. Department of Energy under Contract No. DE-ACO9-89SR18035

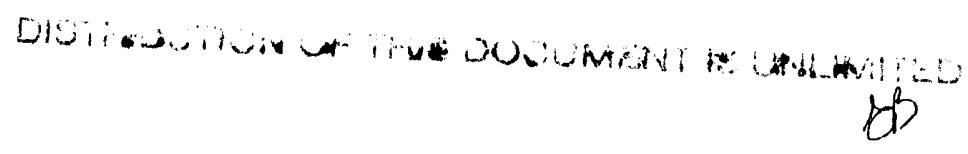


This page intentionally left blank. 


\section{Contents}

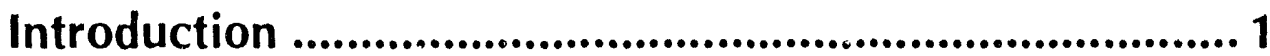

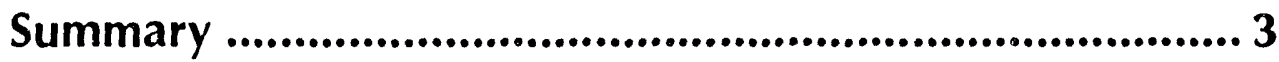

Inspection Program ........................................................... 5

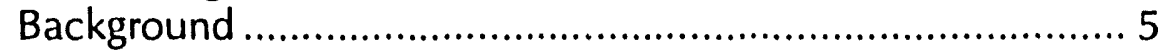

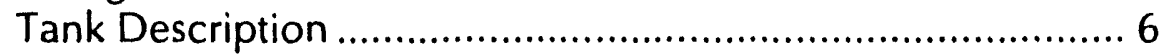

Inspection Methods ......................................................... 10

Program Implementation ............................................ 11

Visual Imagery .................................................................. 11

1993 Inspection Results ..................................................... 11

Summary of Inspection Results ..................................... 11

Appendix A-Waste Tanks at SRS ............................... 17

Appendix B-Summary of 1993 Inspections................... 19

\section{List of Figures}

1. Type I Waste Storage Tank .................................... 6

2. Type II Waste Storage Tank .................................... 7

3. Type IV Waste Storage Tank .................................. 8

4. Type III Waste Storage Tank .................................. 9 
This page intentionally left blank. 


\section{Introduction}

Aqueous radioactive wastes from Savannah River Site (SRS) separations processes are contained in large underground carbon steel tanks. Inspections made during 1993 to evaluate these vessels, and evaluations based on data accrued by inspections made since the tanks were constructed, are the subject of this report. 
This page intentionally left blank. 


\section{Summary}

The 1993 inspection program revealed that the condition of the Savannah River Site waste tanks had not changed significantly from that reported in the previous annual report. No new leaksites were observed. No evidence of corrosion or materials degradation was observed in the waste tanks. However, degradation was observed on covers of the conc, ete encasements for the out-of-service transfer lines to Tanks 1 through 8.

In 1993 a total of 5623 photographs were made and 71 visual and video inspections were performed. 
This page interitionally left blank. 


\section{Inspection Program}

\section{Background}

Alkaline aqueous radioactive wastes produced at the Savannah River Site are stored in underground tanks. The waste comes primarily from nuclear fuel reprocessing operations in the separations areas $(\mathrm{F}$ and $\mathrm{H})$ and contains most of the radioactive fission products from SRS operations. The waste in the tanks is present in three phases: sludge, supernate, and salt formed by supernate evaporation and cooling. The supernate and salt phases consist primarily of $\mathrm{NaNO}_{3}$ and $\mathrm{NaNO}_{2}$. The fission product content is up to 20 curies per gallon for the supernate and up to 60 curies per gallon for the salt. The sludge consists primarily of $\mathrm{MnO}_{2}$ and $\mathrm{Fe}(\mathrm{OH})_{2}$ with a fission product content up to 500 curies per gallon.

Waste tank leak detection capabilities are essential to meet the primary objective of the SRS radioactive waste management program: to manage the waste in such a manner as to minimize the radiation exposure and associated risk to man and his environment over the lifetime of the radionuclides.

The detection of leaked waste is based on two principles: disappearance of material from its proper location and appearance of material in an improper location. At SRS, primary reliance is on the latter because the quantity of the waste detectable in an improper location is much less than that detectable by inventory change in a large tank. Capacity of SRS tanks is 0.75 to 1.3 million gallons. Although rigorous tank inventory surveillance is practiced, primary leak detection methods rely on automatic surveillance of those areas into which the leaked waste is most likely to migrate.

The annulus of each double-wall tank is equipped with at least two single-point conductivity probes for leak detection. These probes are located at the bottom of the annulus and on opposite sides of the tank. The single-wall tanks are built on slabs with a network of leak collection channels that drain to a common sump. Continuous sump level monitoring and frequent sump liquid sampling provide the leak detection. Besides the automatic surveillance, routine direct visual surveys are made in the annular spaces, and nonroutine direct visual surveys are made in primary tanks through opened access risers and/or inspection holes in the roof.
In 1961-62, following leakage of waste into the annulus of Tanks $9,10,14$ and 16, the first remote imaging inspections were made in the annuli of some of the waste tanks, using a periscope. Random inspections continued through 1970. A program was initiated in November 1971 to periodically inspect all waste tanks using remote visual imagery techniques to monitor for corrosion and other degradation, waste leakage, anomalies of any type, and to investigate process or equipment concerns.

Steel thickness measurements have been made periodically of waste tanks using ultrasonic techniques to monitor for general corrosion. An analog-type instrument was used in 1967 and 1969 to measure the thickness of the primary wall of selected double-wall tanks. In 1972, a more precise instrument was put in service. About 24,000 measurements made over a period of 14 years (1972 through 1985) indicated that no thinning of SRS tanks has occurred. The only tank at SRS that has experienced detectable corrosion is Tank 23, a tank with a unique service history. The upper wall interior surfaces show general corrosion with mild pitting. The pitting is broad but shallow. This tank is used to receive contaminated water from $244 \mathrm{H}$, the Receiving Basin for Off-Site Fuels, and 245H, the Resin Regeneration Facility.

Inspections are complicated by factors such as radiation and contamination, remote operation as far as 40 feet below grade, and insertion of equipment through small (generally 5 to 8-inch-diameter) access openings. Inspection techniques to circumvent these difficulties have been developed; they yield good quality photographic records and thickness measurements. The techniques include periscopic systems, direct photographic systems, closed circuit television systems, and a system to measure waste tank wall and bottom plate thicknesses.

Waste tank inspection has been important in leak detection. The leaksites in eight of the ten cracked tanks have been detected by direct visual inspection or by one of the remote inspection techniques. Since the inspection program was initiated in 1971, five tanks were found to have leaksites that were not recognized before inspection. The annulus conductivity probes were not activated by these leaks because of the small amount of leakage. The leaked waste evaporated to dryness, sealing the cracks before any leaked waste reached a conductivity probe. However, remote inspections detected the dry deposits of leaked waste on the walls of these tanks. 
The waste tanks in-service inspection program is comprised of visual imagery inspections and ultrasonic steel thickness measurements. This report gives results of the 1993 visual imagery inspections. No ultrasonic measurements were scheduled or performed in 1993. This report also summarizes foregone inspections and measurements for each waste tank.

\section{Tank Description}

SRS has subsurface storage tanks of four different designs. All of the tanks are constructed of carbon steel and reinforced concrete. They serve as containment vessels for storage and processing of radioactive wastes. Appendix A lists tank location, design type, project number, and construction period. A brief description of the different tank designs is given in the following paragraphs.

\section{Type I Tanks}

The 12 original storage tanks constructed between 1951 and 1953 are designated type I tanks. Tanks 1 through 8 are in F Area and Tanks 9 through 12 are in H Area. Each primary tank has a capacity of 750,000 gallons, is 75 feet in diameter, and $241 / 2$ feet high. Figure 1 shows the essential features of type I tanks, including the primary tank, the secondary pan, and the concrete support structure.

The primary container is a closed cylindrical tank with flat top and bottom constucted from 1/2-inch-thick steel plates. The top and bottom are joined to the cylindrical sidewall by curved knuckle plates. The primary tank is set within a circular pan of $1 / 2$-inch-thick steel plates. The annulus pan is 5 feet deep and 5 feet larger in diameter than the tank, thus forming an annular space $21 / 2$ feet wide. The tank and pan are set on a 30-inch-thick base slab and are enclosed by a cylindrical 22-inch-thick reinforced concrete wall and a flat concrete roof, also 22 inches thick. There are twelve 2-foot-diameter concrete columns within the primary tank to support the roof. Each column has a flared capital and is encased in 1/2-inch-thick steel plate.

A 9-foot layer of earth was placed over the tanks for radiation shielding. Cooling for each type I tank is provided by 36 parallel (water pipe) cooling coils.

A dehumidification duct in the annulus of each tank is routed from the tank top to the bottom of the annulus where it encircles the tank. The duct has distribution outlets and its cross-sectional area decreases as the distance from the air supply increases. Access to the tank interior is provided at eight locations, and to the annular space at four locations, through riser pipes. Each of the 12 riser pipes is capped at the top with a concrete plug. Each plug is provided with two 5 -inch-diameter ports equipped with removable plugs. Some of these ports provide access for inspections.

All welds in the pan and primary tank were radiographically inspected, defects were corrected, and the welds were rechecked radiographically. The welds in the flat bottoms of both the pan and the tank were vacuum-tested for leaks. Additionally, both vessels were hydrostatically

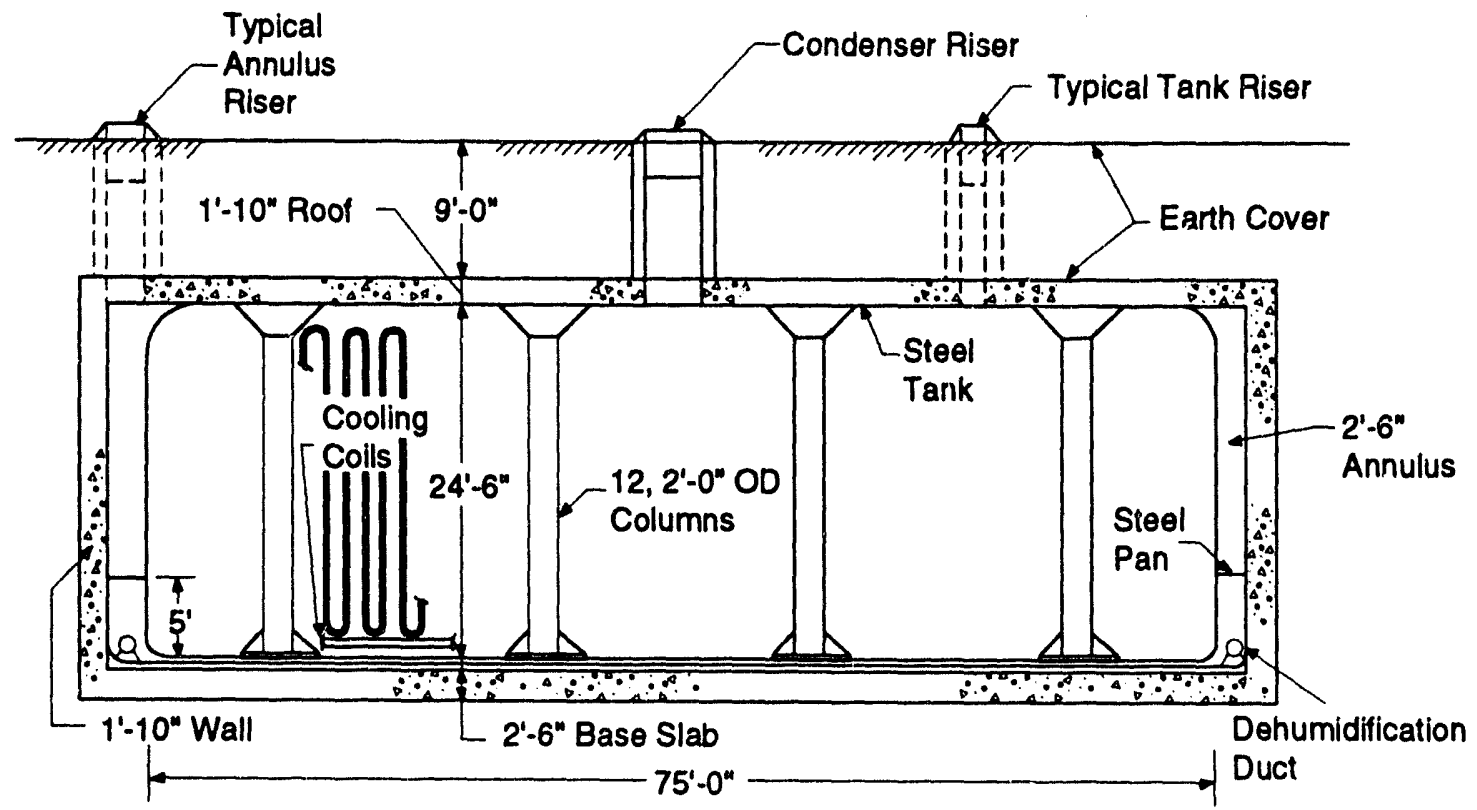

Figure 1. Cooled Waste Storage Tank, Type I (Original 750,000 Gallons). 


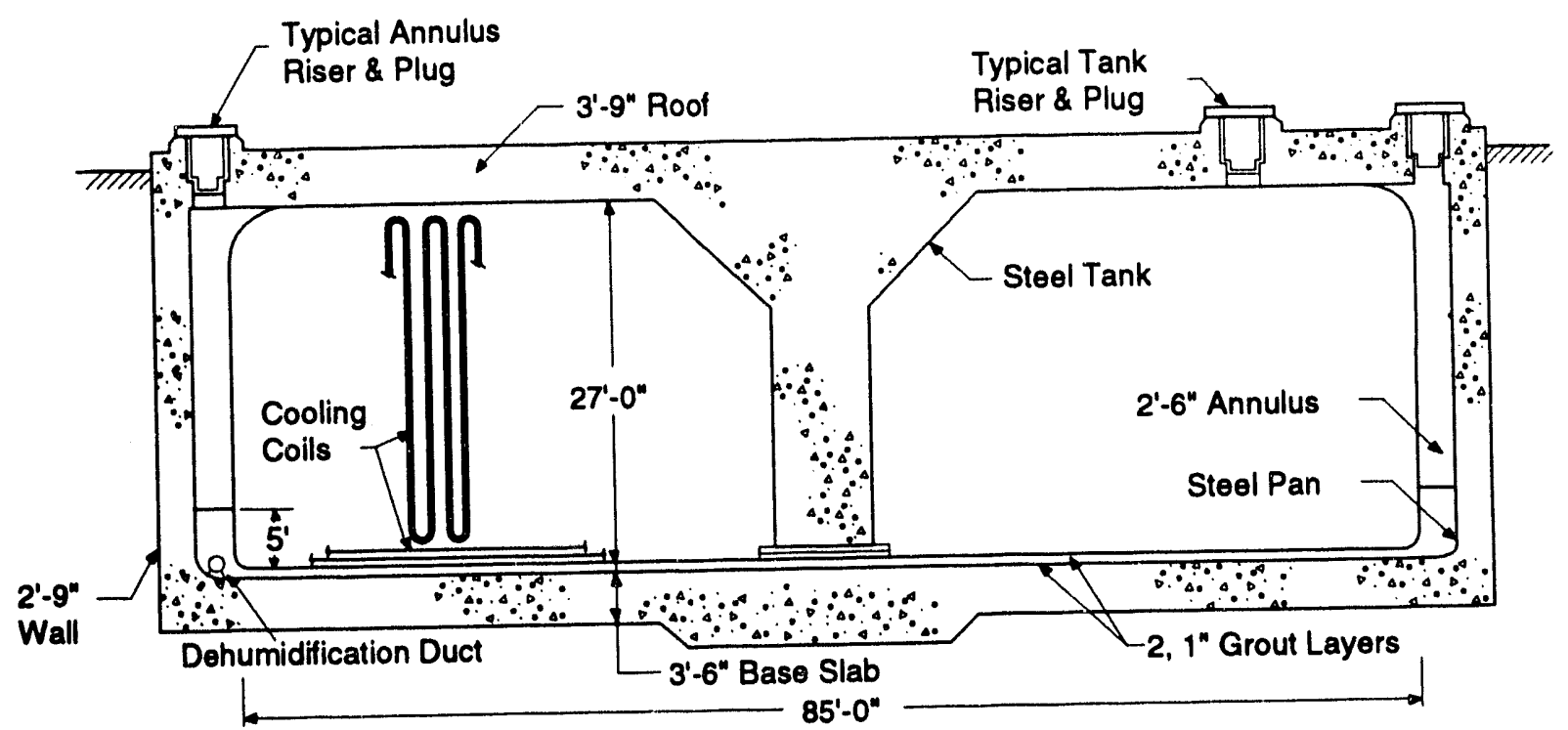

Figure 2. Cooled Waste Storage Tank, Type II (Original 1,030,000 Gallons).

tested. The water vas maintained at full height in the tank for 24 hours before inspection for leaks was made. Cooling water piping was hydrostatically tested at $300 \mathrm{psig}$ and then leak-tested with 100 psig air pressure in the piping.

\section{Type II Tanks}

Tanks 13 through 16, constructed in H Area in 1955 and 1956, are designated type II tanks. Figure 2 is a cross section of this type. Each primary tank has a capacity of $1,030,000$ gallons and is 85 feet in diameter and 27 feet high.

The primary container for type II tanks consists of two concentric steel cylinders assembled with a flat bottom anc a flat top into a form somewhat like a doughnut. The top and bottom are joined to the outer cylinder by rings of curved knuckle plates. The inner cylinder is flared at the top to accommodate the roof support column. This cylinder is joined to the flat steel top with a continuous butt weld, and to a base fastened to the bottom with a continuous T-weld. Steel thicknesses are:

\begin{tabular}{lc}
\multicolumn{1}{c}{ Plate } & Thlckness, inch \\
\hline Top and bottom & $1 / 2$ \\
Upper knuckle & $9 / 16$ \\
Wall & $5 / 8$ \\
Lower knuckle & $7 / 8$
\end{tabular}

The primary tank is set on a 1 -inch sand bed within a circular pan of 1/2-inch-thick steel plate, 5 feet deep and 5 feet larger in diameter than the tank, thus forming an annular space $21 / 2$ feet wide. The tank and pan assembly is surrounded by a cylindrical reinforced concrete enclosure with a 33-inch-thick wall and a flat concrete roof that is $\mathbf{4 5}$ inches thick. The tank and pan assembly and the surrounding wall are set on a foundation slab that is $\mathbf{4 2}$ inches thick. The roof is supported by both the wall and a central concrete column that fits within the inner cylinder of the vessel. The 45 -inch-thick concrete roof provides radiation shielding; therefore, no earth overburden is required. Cooling for each type II tank is provided by 44 parallel (water pipe) cooling coils. Access to the tank interior is provided at eight locations, and to the annular space at four locations, through riser pipes. Each of the 12 riser pipes is capped at the top with a concrete plug. Each plug is provided with two 5 -inch-diameter ports equipped with removable plugs. The ports provide access for inspection. In addition to the four annulus risers, other access openings (10 to 14 additional openings per tank) have been drilled into the annulus of each of these tanks to permit inspection of seventy-three to ninety-six percent of the exterior walls of the primary vessels.

A dehumidification duct in the annulus of each tank is routed from the tank top to the bottom of the annulus where it encircles the tank. The duct has distribution outlets and its cross-sectional area decreases as the distance from the air supply increases.

All welds in the primary tanks were radiographically inspected, defects were corrected, and the welds were rechecked radiographically. However, the annulus pans were not inspected radiographically. The welds in the flat bottoms of these pans and the primary tanks were vacuumtested for leaks, and the primary and secondary vessels 
were hydrostatically tested. Cooling water piping was hydrostatically tested at $300 \mathrm{psig}$ and then leak-tested, with 100 psig air pressure in the piping.

\section{Type IV Tanks}

Tanks 17 through 24 are single-wall uncooled tanks. These tanks were designed for storage of waste that does not require auxiliary cooling. Tanks 17 through 20 were constructed in F Area in 1958 and Tanks 21 through 24 were constructed in H Area between 1959 and 1961. Each tank has a capacity of 1,300,000 gallons and is 85 feet in diameter and 34 feet high (Figure 3).

Each type IV tank is basically a steel-lined, prestressedconcrete tank in the form of a vertical cylinder with a domed roof. Carbon steel plates, 3/8 inch thick, were used to form the cylindrical sides and flat bottom portion of the steel liners. The knuckle plates at the junction of the bottom and the sidewall are 7/16 inch thick. Concrete was built up around the steel vessel by the "shotcrete" technique.

Radiation shielding of the type IV tanks in F Area was accomplished by applying at least 32 inches of earth over each of the 7-inch-thick concrete domes. H-Area tanks were shielded similarly, except that the earth cover was at least $\mathbf{4 4}$ inches thick to accommodate a somewhat higher radiation level from the waste.

Access to the interior of the tank is provided at six locations through riser pipes. Each riser pipe is capped at the top with a concrete plug. Some of these risers provide access for inspection.

All welds in the steel liners were radiographically inspected. All of the welded tank-bottom seams and the upper seams of the knuckle rings were vacuum leaktested. Prior to the back-filling operation, each tank was hydrostatically tested by filling with water to the normal fill line. The tank was allowed to remain filled until it was to be placed in use for waste storage.

\section{Type III Tanks}

The most recently constructed tanks are designated as type III tanks (Figure 4). Twenty-seven tanks were built between 1967 and 1981. Tanks 25 through 28, 33 and 34, and 44 through 47 are located in F Area. Tanks 29 through 32, 35 through 43 and 48 through 51 are located in H Area.

The type III tank design was developed after an investigation into the causes of the leaks from the primary vessel of the type I and type II tanks. The study concluded that the leak-producing mechanism was nitrate stress-corrosion cracking at sites in or near the weld seams, and that stress relieving after fabrication should eliminate the cracking. For the type III tanks, means were provided for heating each finished tank to relieve the stresses generated during fabrication. In addition, some stress patterns were avoided, or minimized, by mounting the roof supporting column on the foundation pad rather than on the bottom of the primary tank (as in types I and II), and by providing an annular clearance around the roof supporting column. Each

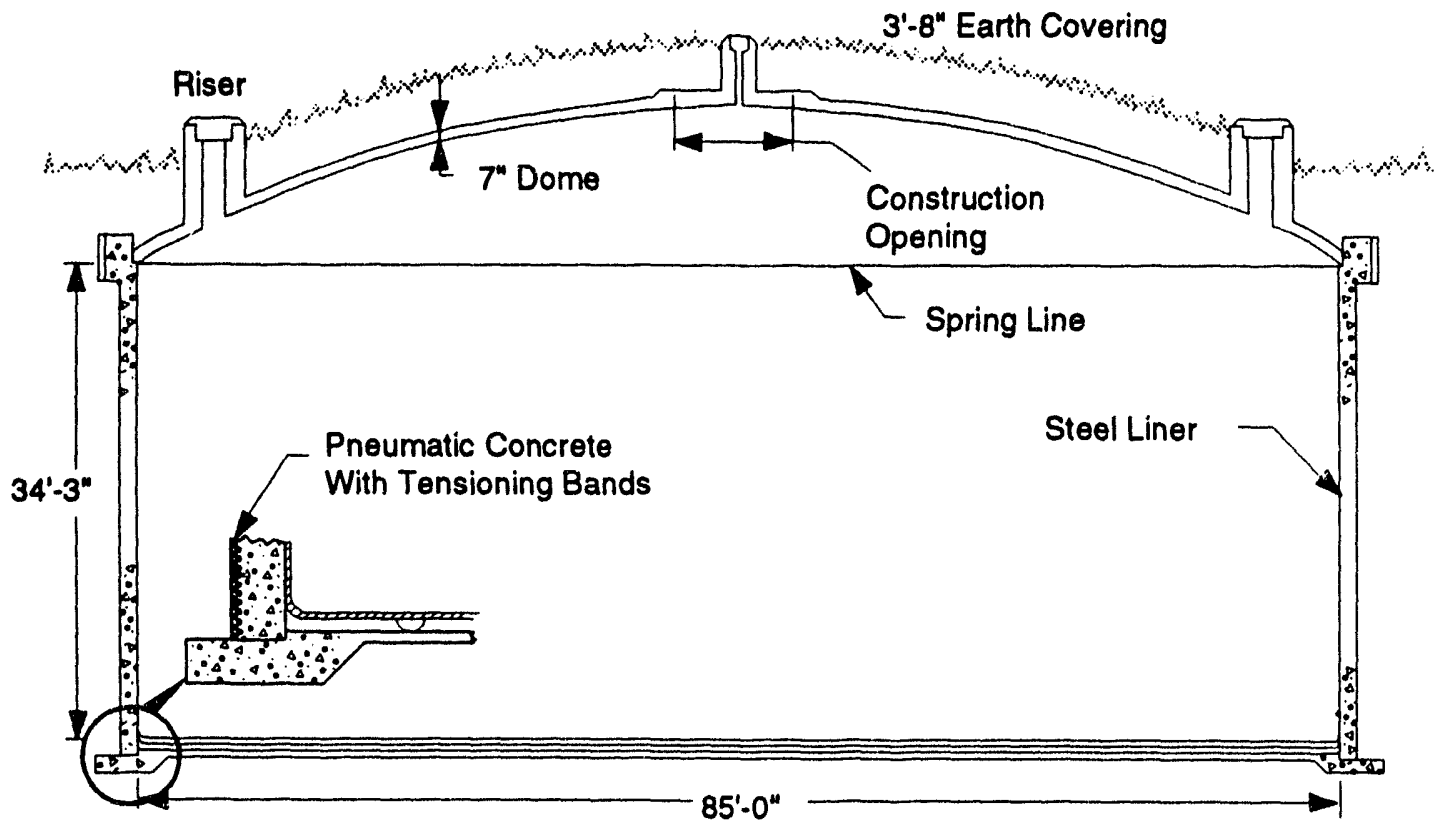

Figure 3. Uncooled Waste Storage Tank, Type IV (Prestressed Concrete Walls, 1,300,000 Gallons). 


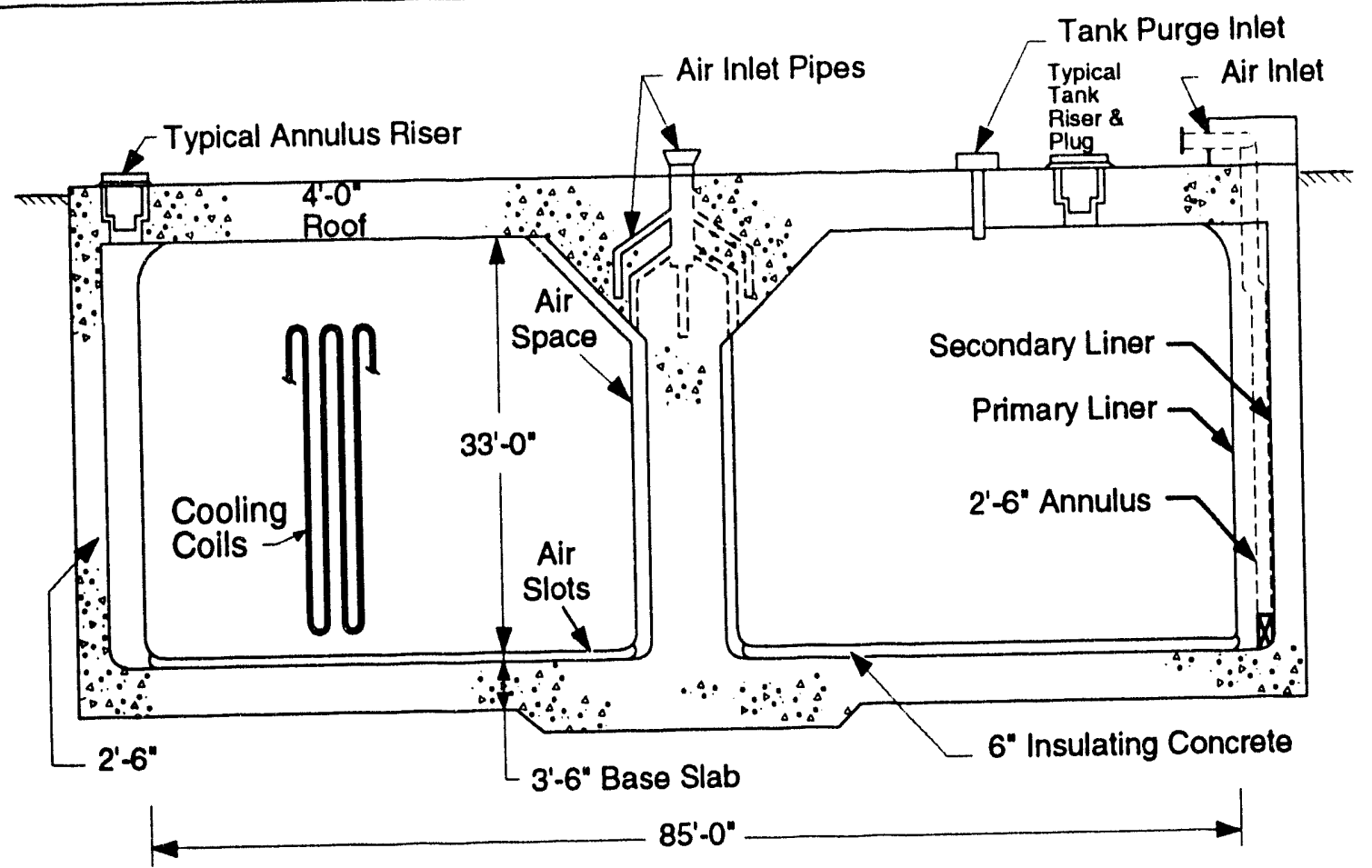

Figure 4. Cooled Waste Storage Tank, Type III (Stress Relieved Primary Liner, 1,300,000 Gallons).

primary tank holds $1,300,000$ gallons and is 85 feet in diameter and 33 feet high.

Type III tanks are similar to the doughnut-like design of type II tanks. Each primary vessel is made of two concentric cylinders joined to washer-shaped top and bottom plates by curved knuckle plates. Steel thicknesses are:

\begin{tabular}{lc}
\multicolumn{1}{c}{ Plate } & Thickness, inch \\
\hline Top and bottom & $1 / 2$ \\
Upper knuckle & $1 / 2$ \\
Outer wall & \\
Upper band & $1 / 2$ \\
Middle band & $5 / 8$ \\
Lower band & $3 / 4$ \\
Inner wall & \\
Upper band & $1 / 2$ \\
Lower band & $5 / 8$ \\
Lower knuckle & \\
Outer & $7 / 8(25-28$ and $33-51)$ \\
& 1 (tanks 29 thruugh 32$)$ \\
Inner & $5 / 8$
\end{tabular}

The primary tank is set on a 6-inch bed of insulating concrete within the secondary containment vessel. The concrete bed is grooved radially so that ventilating air can flow from the inner to the outer annulus, if any waste were to leak from the tank bottom or center annulus wall, liquid would move through the grooves, facilitating detection in the outer annulus.

The secondary vessel is 5 feet larger in diameter than the tank, thus providing an outer annulus $21 / 2$ feet wide. The secondary vessel is made of 3/8-inch-thick steel throughout. Its sidewalls rise to the full height of the primary tank. The nested two-vessel assembly is surrounded by a cylindrical reinforced concrete enclosure with a 30-inch-thick wall. The enclosure has a 48-inch-thick flat reinforced concrete roof that is supported by the concrete wall and a central column that fits within the inner cylinder of the vessel. The 48 -inch-thick concrete provides radiation shielding; hence, no earth overburden is required.

Cooling for the type III tank is provided by either deployable (water pipe) cooling coil bundles installed through risers in the tank top, or 23 parallel (water pipe) cooling coils distributed throughout the tank.

A dehumidification duct in the annulus of each tank is routed from the tank top to the bottom of the annulus where it encircles the tank. The duct has distribution outlets and its cross-sectional area decreases as distance from the air supply increases. In these tanks, additional airflow is directed through the inner annulus, passing beneath the primary tank through radial grooves in the concrete base slab, and is exhausted into the outer annulus. 
Tanks 29 through 34 were placed in service prior to 1976. These tanks were constructed with annulus riser pipes at four locations providing inspection access through 5 -inchdiameter ports. All other type III tanks were placed in service after 1976 and have annulus riser pipes at 18 locations that are 8 -inches in diameter. These ports are equidistant around the tank and provide for inspection of all of the exterior wall of the primary vessel. In 1982, fourteen to sixteen additional 8-inch diameter ports per tank were drilled in the tops of Tanks 29 through 34 to provide adequate access ports for inspection of all of the exterior walls of their primary vessels. All type III tanks have interior riser pipes at various locations, which provide inspection access through ports having diameters of 5 to 8 inches. All inspection access ports are equipped with removable plugs.

All butt welds on the primary tanks were radiographically inspected except welds on the horizontal roof surface. On the secondary vessels of Tanks 29 through 34, all butt welds joining bottom plates, knuckle plates, and the lowest courses of center-column and outer-wall plates, were radiographically inspected. On all other type III tanks, all plate welds in the secondary tanks were radiographically inspected. All defects were corrected and the welds were rechecked radiographically.

The Quality Assurance Program included inspection of all radiographs by two independent groups of certified weld inspectors, and all radiographs were permanently stored for future reference. All spots on the inside or outside of the primary tanks and the inside of the secondary tanks, where clips or lugs were removed and where other excisions were made, were examined by magnetic particle or liquid penetrant techniques, and any defects were repaired.

All butt welds on the secondary tanks were vacuum leaktested. All welds in the bottom assemblies of the primary tanks, including knuckle rings and lowest course welds, were vacuum leak-tested before each bottom assembly was lowered into final position, and then tested a second time after the stress-relieving operation. A full hydrostatic test, the filling of each primary tank to a depth of $32 \mathrm{ft}$ and allowing it to stand 48 hours, was conducted after stress relieving. No leaks were found by the hydrostatic tests. All circumferential welds in the pipe loops of the deployable cooling coil bundles below the $1 / 2$-inch-thick plate at the base of the riser plug were radiographed. The assernbled cooler piping was tested hydrostatically to $500 \mathrm{psig}$ and halide leak-tested at $300 \mathrm{psig}$. Welds in the distributed cooling coils were radiographed and similarly leak-tested.
The primary tank was stress-relieved in place after all high temperature work (other than roof attachments) had been completed. Full stress relief, at $11(0) 0^{\circ} \mathrm{F}$, was accomplished in accordance with the general requirements of the ASME Boiler and Pressure Vessel code.

\section{Inspection Methods}

Techniques have been developed for remote examination and evaluation of the waste tanks and ancillary equipment. For visual imaging, direct photography systems developed at SRS were the primary method used. Optical periscopes, boroscopes, and closed circuit telcvision systems were also used where direct photography was not possible, or where these systems provided a morc comprchensive examination. Only the direct photography systems will be described, since the other systems were used less frequently and are similar to systems used widely in the nuclear industry. Thickness measuring equipment will not be discussed since stecl thickness measurements were not made during 1993.

Wide-angle direct photography was used for general inspections of double-wall tank annuli and the primary vessels of both double-wall tanks and single-wall tanks. This technique uses a $35 \mathrm{~mm}$ Zeiss-lkon Hologon Ultrawide camera that surveys a large area in a single photograph. The lens is a $15 \mathrm{~mm} \mathrm{f} / 8$ fixed aperture and fixed focus with a field of focus from $181 / 2$ inches to infinity. The lens is distortion free with a 100-degree ficld of view. A bank of four electronic flash units are synchronized with the camera to provide illumination. The camera is not shielded since residence time in a tank is only a few seconds.

Another direct photography technique was used for detailed inspections. The camera is shielded to reduce the degrading effect of ionizing radiation on the photographic film. The camera's residence time in a waste tank for this technique is longer than for the wide-angle direct photographic technique, i.e., a few minutes versus a few seconds; hence, shielding is required. The camera used is the $35 \mathrm{~mm}$ Leitz's Leica CL. It is a rangefinder camera with interchangeable lenses. Normally a $21 \mathrm{~mm}$ lens is used for tank inspection. Alternate lenses are available with focal lengths of $28 \mathrm{~mm}$ and $35 \mathrm{~mm}$. Illumination is provided by a single electronic flash unit. 


\section{Program Implementation}

\section{Visual Imagery}

The 1993 inspection program used three visual imagery techniques: photography, closed circuit television, and periscopic inspection. The primary inspection methods were direct photography techniques, e.g., making a series of photographs providing detailed views of the tank, and wide-angle photography for obtaining overviews of large areas. Closed circuit television systems and periscopes were generally used to further investigate conditions found during scheduled inspections, and to troubleshoot process problems in tanks and ancillaries.

The primary purpose of the inspection program is the continuing evaluation of the condition of waste tanks. This objective was satisfied in 1993 by photographic documentation. The policy developed for photographic inspections in 1972 specified biennial inspection in the annuli of all waste tanks, and annual inspection of those tanks in which waste had breached the primary vessel. Biennial inspections do not include all annulus risers. Therefore, the time required to inspect a tank through all annulus risers could be as long as four years. However, the wide-angle direct photography method developed in 1974 was used to make annual inspections through all risers where inspections were not made by other photographic methods. Hence, inspections were made through all accessible annulus risers of the double-wall tanks, and at least one inspection was made in the interior of each single-wall tank.

Inspections in Tanks 1 through 12 are limited to approximately $25 \%$ of the exterior of the primary vessel walls and their annular spaces. This is considered adequate since the tanks are inactive, i.e., waste is not routinely transferred to or from them. These tanks are continuously monitored for leakage by instrumentation installed in their annuli. Additionally, for those tanks that have known leaksites in the primary vessel, the supernate phase has been removed, minimized, or the level lowered below the level of known leaksites.

\section{Inspection Results}

The 1993 inspection program was successfully completed. The annuli of all double-wall tanks and the interiors of single-wall tanks were inspected at accessible risers by at least one photographic technique. Other inspections were made as required by operating conditions and equipment performance. All inspections made in 1993 are listed in Appendix B.

The inspections made in 1993 revealed that the condition of the waste tanks was virtually unchanged since inspection in 1992. No new leaksites were found and no evidence was observed that any of the existing leaksites had leaked since inspection in 1992. No significant corrosion of the tanks was evidenced, by the lack of change on the steel surfaces.

Inspections made in the concrete encasement for the outof-service transfer lines to Tanks 1 through 8 revealed some degradation of the encasement covers. Surface cracks and minor spalling were observed on the bottom of one of the 12-inch-thick concrete covers. Another cover had cracked and slumped down into the encasement a few inches. These observations were made in November and December 1993. Inspections and structural integrity evaluation continued beyond the December 31 cutoff date of this report.

Rainwater continued to leak into the annuli of several tanks. Water inleakage was evidenced by surface stains and occasionally by calcite deposits. The leakage was primarily due to poor seals at riser plug gaskets and failed seals where process pipes penetrate the tank annuli below grade.

\section{Summary of Inspection Results}

The following is a brief description of tank conditions as revealed by inspections and examinations made through 1993.

\section{Tank 1}

Tank 1 was placed in service in 1954. A small amount of dry waste was observed on the annulus floor in 1969. Subsequent inspections have revealed no additional leakage. Inspection of the exterior wall of the primary vessel is limited to $25 \%$ using existing inspection techniques through the four risers that provide access to the annulus. Examination of the observable portion of the tank wall has not revealed the location of the leak(s). Inspection photographs of the steel surface of the tank and the annulus have shown no significant surface corrosion or other anomalies. Ultrasonic measurements made in 1978, 1979, 1981, 
1983, and 1985 showed that no detectable thinning of the tank wall had occurred.

\section{Tank 2}

Tank 2 was placed in service in 1955. Examinations of the observable portion (25\%) of the exterior of the primary vessel wall and the annulus have shown no leakage, significant surface corrosion, or other anomalies. Ultrasonic measurements made in 1967, 1972,1973,1977, 1981, and 1985 showed no detectable thinning of the tank wall.

\section{Tank 3}

Tank 3 was placed in service in 1956. Examinations of the observable portion $(25 \%)$ of the exterior of the primary vessel wall and the annulus have shown no leakage, significant surface corrosion, or other anomalies. Ultrasonic measurements made in 1973, 1977, 1981, and 1985 showed no detectable thinning of the tank wall.

\section{Tank 4}

Tank 4 was placed in service in 1961. Examinations of the observable portion (2.5\%) of the exterior of the primary vessel wall and the annulus have shown no leakage, significant surface corrosion, or other anomalies. Ultrasonic measurements made in 1973,1977, 1981, and 1985 showed no detectable thinning of the tank wall.

\section{Tank 5}

Tank 5 was placed in service in 1959. Examinations of the observable portion (25\%) of the exterior of the primary vessel wall and the annulus have shown no leakage, significant surface corrosion, or other anomalies. Ultrasonic measurements made in 1973, 1977, 1981, and 1985 showed no detectable thinning of the tank wall.

\section{Tank 6}

Tank 6 was placed in service in 1964. Examinations of the observable portion (25\%) of the exterior of the primary vessel wall and the annulus have shown no leakage, significant surface corrosion, or other anomalies. Ultrasonic measurements made in 1974, 1977, 1978, 1979, 1981, and 1985 showed no detectable thinning of the tank wall.

\section{Tank 7}

Tank 7 was placed in service in 1954. Examinations of the observable portion (25\%) of the exterior of the primary vessel wall and the annulus have shown no leakage, significant surface corrosion, or other anomalies. Ultrasonic measurements made in 1974, 1979, 1981, 1983, and 1985 showed no detectable thinning of the tank wall.

\section{Tank 8}

Tank 8 was placed in service in 1956. Examinations of the observable portion (25\%) of the exterior of the primary vessel wall and the annulus have shown no leakage, significant surface corrosion, or other anomalies. Ultrasonic measurements made in 1973, 1977, 1981, and 1985 showed no detectable thinning of the tank wall.

\section{Tank 9}

Tank 9 was placed in service in 1955. Leakage from the tank primary vessel into the annulus pan may have occurred as early as 1955 when the "necklace" alarm, a conductivity leak detection device, shorted out permanently. Leakage was not certain until liquid waste was observed in the annulus pan in 1957. Currently, the annulus pan contains 8 to 10 inches of dry leaked waste. Examinations of the observable portion $(25 \%)$ of the exterior of the primary vessel wall have shown three leaksites high on the tank wall; 269, 271, and 276 inches above the tank bottom. None of these leaksites is the source of the leaked waste in the annulus pan. The waste leaked at these sites was only enough to form localized small nodules. The leak(s) that is the source of the waste in the annulus pan has not been observed. Inspections have shown no significant surface corrosion, and the ultrasonic measurements made in 1979 and 1983 showed no detectable thinning of the tank wall.

\section{Tank 10}

Tank 10 was placed in service in 1955 . The first indication that Tank 10 had leaked was in 1959 when dry waste was discovered in the annulus pan during a visual inspection. Currently, the annulus pan contains about 2 inches of dry leaked waste. Examinations of the observable portion $(25 \%)$ of the exterior of the primary vessel wall have not shown the source of the leaked waste or any other leaksite(s). Inspections have shown no significant surface corrosion, and the ultrasonic measurements made in 1979 and 1983 showed no detectable thinning of the tank wall.

\section{Tank 11}

Tank 11 was placed in service in 1955 . Twenty-five percent of the exterior of the primary vessel wall is observable via the four risers that provide access to the annulus. Inspections performed in 1974 revealed two leaksites. The leaksites are 189 and 235 inches above the tank bottom. Inspections have shown no significant surface corrosion and ultrasonic measurements made in 1973, 1977, 1981, and 1985 showed no detectable thinning of the tank wall. 


\section{Tank 12}

Tank 12 was placed in service in 1956. Twenty-five percent of the exterior of the primary vessel wall is observable via the four risers that provide access to the annulus. Inspections in 1974 revealed two leaksites. The leaksites are 93 and 105 inches above the tank bottom. Inspections have shown no significant surface corrosion and ultrasonic measurements made in 1972, 1973, 1977, 1981, 1983, and 1985 showed no detectable thinning of the tank wall.

\section{Tank 13}

Tank 13 was placed in service in 1956 . Ninety percent of the exterior of the primary vessel wall is observable via the 13 risers that provide access to the annulus. Inspections in 1977 revealed a leaksite 279 inches above the tank bottom. In 1980 another leaksite was discovered 269 inches above the tank bottom. Inspections have shown no significant surface corrosion and ultrasonic measurements made in 1974, 1979, and 1985 showed no detectable thinning of the tank wall.

\section{Tank 14}

Tank 14 was placed in service in 1957. The first indication that tank 14 had leaked was in 1959 when dry leaked waste was observed in the annulus pan. Currently the annulus pan contains 12 to 13 inches of dry leaked waste. Eighty-nine percent of the exterior of the primary vessel wall is observable via the 18 risers that provide access to the annulus. Inspections have located 33 leaksites and it is estimated that there are about 50 leaksites in this tank. All of the observed leaksites are near the bottom circumferential weld that is 2.5 feet above the tank bottom, except one leaksite that was observed approximately 24 feet above the tank bottom Inspections have shown no significant surface corrosion and ultrasonic measurements made in 1979 and 1983 showed no detectable thinning of the tank wall.

\section{Tank 15}

Tank 15 was placed in service in 1960. Inspections in 1972 below one of the four risers providing access to the annulus revealed two leaksites near the bottom circumferential weld about 2.5 feet above the tank bottom. Twelve additional risers were installed increasing the observable portion of the primary vessel wall from 25\% to $96 \%$. Inspections in 1973 via the additional risers revealed eleven other leaksites. No additional leaksites have been found since 1973. Inspections have shown no significant surface corrosion and ultrasonic measurements made in 1972, 1977, 1980, and 1984 showed no detectable thinning of the tank wall.

\section{Tank 16}

Tank 16 was placed in service in 1959. Liquid waste was detected in the annulus pan in 1959. Seventy-three percent of the exterior wall of the primary vessel is observable via the sixteen risers that provide access to the annulus. Inspections in 1961 and 1962, through 13 risers, revealed about 175 leaksites in the tank wall. In October 1961 and March 1962, two 5 3/4-inch-diameter samples were cut from the top horizontal circumferential weld of the tank wall about 40 feet apart. Metallurgical examination indicated the cause of the cracks was nitrate induced stress corrosion. Extensive inspection performed since 1972 indicated that the primary vessel wall has 300 to 350 leaksites. In $1978,70 \%$ of the leaked waste in the annulus pan was removed, leaving an insoluble heel containing approximately 30,000 curies of $137 \mathrm{Cs}$. Waste removal from the interior of the primary vessel was completed in 1980. Inspections have shown no significant surface corrosion. No ultrasonic steel thickness measurements of the tank were made because of the number of leaksites and the presence of leaked waste deposits on the primary vessel exterior. This tank is "out of service".

\section{Tank 17}

Tank 17 was placed in service in 1961. Examinations of the steel liner have shown no evidence of failure, signifcant surface corrosion, or other anomalies.

\section{Tank 18}

Tank 18 was placed in service in 1959. Examinations of the steel liner have shown no evidence of failure, significant surface corrosion or other anomalies. Ultrasonic measurements made in 1977, 1980, and 1983 showed no detectable thinning of the liner bottom.

\section{Tank 19}

Tank 19 was placed in service in 1961. Examinations of the steel liner have shown no evidence of failure, significant surface corrosion, or other anomalies. Ultrasonic measurements made in 1982 and 1985 showed no detectable thinning of the liner bottom.

\section{Tank 20}

Tank 20 was placed in service in 1960. Examinations of the steel liner have revealed four failure sites. In 1983, leaksites were observed in the wall of the steel liner at heights of 22, 24.5, and 26.5 feet. In 1990, a leaksite was confirmed in the liner wall at a height of 26.25 feet. This site had been suspect since 1984 . 
This is a single-wall tank with no annulus. The leaksites in the steel liner were detected by inspections made from the tank interior, since inspection of the exterior was not possible. Artifacts observed on the interior wall indicated that water had leaked through the steel liner into the tank. It is possible that a small quantity of waste may have leaked from the steel liner. However, groundwater monitoring has given no indication that waste escaped the encasement.

\section{Tank 21}

Tank 21 was placed in service in 1961. Examinations of the steel liner have shown no evidence of failure, significant surface corrosion, or other anomalies. Ultrasonic measurements made in 1973,1977, 1980, and 1983 showed no detectable thinning of the liner bottom.

\section{Tank 22}

Tank 22 was placed in service in 1965. Examinations of the steel liner have shown no evidence of failure, significant surface corrosion, or other anomalies. Ulirasonic measurements made in 1974, 1977, 1980, and 1983 showed no detectable thinning of the liner bottom.

\section{Tank 23}

Tank 23 was placed in service in 1964. Examinations of the steel liner have revealed corrosion but no evidence of failure. Ultrasonic measurements made in 1973, 1977 , 1980, and 1983 showed no detectable thinning of the liner bottom. Examinations of the steel liner have shown rust and tubercles on the surface of the upper portion. This tank serves as a receiver tank for inhibited contaminated water from buildings $244 \mathrm{H}$ (the Receiving Basin for Off-Site Fuels) and 245H (the Resin Regeneration Facility). The tank was filled to less than $50 \%$ capacity to reserve the remaining space for emergency use. This mode of operation exposed only the lower half of the tank to the inhibited contents, and exposed the upper half of the tank to a warm humid atmosphere. In 1984, rust and tubercles were cleaned from two small areas, exposing the steel surface. The cleaned liner surface was generally corroded, with mild pitting. The pits were broad and shallow.

\section{Tank 24}

Tank 24 was placed in service in 1963. Examinations of the steel liner have shown no evidence of failure, significant surface corrosion, or other anomalies. Ultrasonic measurements made in 1984 showed no detectable thinning of the liner bottom.
Tank 25

Tank 25 was placed in service in 1980. Examinations of $100 \%$ of the exterior of the primary vessel wall and the annulus have shown no leakage, significant surface corrosion, or other anomalies. Ultrasonic thickness measurements made in 1979 and 1983 showed no detectable thinning of the tank wall.

\section{Tank 26}

Tank 26 was placed in service in 1980. Examinations of $100 \%$ of the exterior of the primary vessel wall and the annulus have shown no leakage, significant surface corrosion, or other anomalies. Ultrasonic thickness measurements made in 1979 and 1983 showed no detectable thinning of the tank wall.

\section{Tank 27}

Tank 27 was placed in service in 1980. Examinations of $100 \%$ of the exterior of the primary vessel wall and the annulus have shown no leakage, significant surface corrosion, or other anomalies. Ultrasonic thickness measurements made in 1979 and 1983 showed no detectable thinning of the tank wall.

\section{Tank 28}

Tank 28 was placed in service in 1980. Examinations of $100 \%$ of the exterior of the primary vessel wall and the annulus have shown no leakage, significant surface corrosion, or other anomalies. Ultrasonic thickness measurements made in 1979 and 1983 showed no detectable thinning of the tank wall.

\section{Tank 29}

Tank 29 was placed in service in 1971. Examinations of $100 \%$ of the exterior of the primary vessel wall and the annulus have shown no leakage, significant surface corrosion, or other anomalies. Ultrasonic thickness measurements made in 1973 and 1974 showed no detectable thinning of the tank wall.

\section{Tank 30}

Tank 30 was placed in service in 1974. Examinations of $100 \%$ of the exterior of the primary vessel wall and the annulus have shown no leakage, significant surface corrosion, or other anomalies. Ultrasonic thickness measureinents made in 1975 showed no detectable thinning of the lank wall. 


\section{Tank 31}

Tank 31 was placed in service in 1972. Examinations of $100 \%$ of the exterior of the primary vessel wall and the annulus have shown no leakage, significant surface corrosion, or other anomalies.

\section{Tank 32}

Tank 32 was placed in service in 1971. Examinations of $100 \%$ of the exterior of the primary vessel wall and the annulus have shown no leakage, significant surface corrosion, or other anomalies.

\section{Tank 33}

Tank 33 was placed in service in 1969. Examinations of $100 \%$ of the exterior of the primary vessel wall and the annulus have shown no leakage, significant surface corrosion, or other anomalies.

\section{Tank 34}

Tank 34 was placed in service in 1972. Examinations of $100 \%$ of the exterior of the primary vessel wall and the annulus have shown no leakage, significant surface corrosion, or other anomalies.

\section{Tank 35}

Tank 35 was placed in service in 1977. Examinations of $100 \%$ of the exterior of the primary vessel wall and the annulus have shown no leakage, significant surface corrosion, or other anomalies. Ultrasonic thickness measurements made in 1977, 1981, and 1985 showed no detectable thinning of the tank wall.

\section{Tank 36}

Tank 36 was placed in service in 1977. Examinations of $100 \%$ of the exterior of the primary vessel wall and the annulus have shown no leakage, significant surface corrosion, or other anomalies. Ultrasonic thickness measurements made in 1977, 1981, and 1985 showed no detectable thinning of the tank wall.

\section{Tank 37}

Tank 37 was placed in service in 1978. Examinations of $100 \%$ of the exterior of the primary vessel wall and the annulus have shown no leakage, significant surface corrosion, or other anomalies. Ultrasonic thickness measurements made in 1977, 1981, and 1985 showed no detectable thinning of the tank wall.

\section{Tank 38}

Tank 38 was placed in service in 1981. Examinations of $100 \%$ of the exterior of the primary vessel wall and the annulus have shown no leakage, significant surface corrosion, or other anomalies. Ultrasonic thickness measurements made in 1980, 1981, and 1984 showed no detectable thinning of the tank wall.

\section{Tank 39}

Tank 39 was placed in service in 1982. Examinations of $100 \%$ of the exterior of the primary vessel wall and the annulus have shown no leakage, significant surface corrosion, or other anomalies. Ultrasonic thickness measurements made in 1980,1981, 1984, and 1985 showed no detectable thinning of the tank wall.

\section{Tank 40}

Tank 40 was placed in service in 1986. Examinations of $100 \%$ of the exterior of the primary vessel wall and the annulus have shown no leakage, significant surface corrosion, or other anomalies. Ultrasonic thickness measurements made in 1980,1981, and 1984, before putting the tank in service, showed no change in the wall thickness.

\section{Tank 41}

Tank 41 was placed in service in 1982. Examinations of $100 \%$ of the exterior of the primary vessel wall and the annulus have shown no leakage, significant surface corrosion, or other anomalies. Ultrasonic thickness measurements made in 1980, 1981, and 1984 showed no detectable thinning of the tank wall.

\section{Tank 42}

Tank 42 was placed in service in 1982. Examinations of $100 \%$ of the exterior of the primary vessel wall and the annulus have shown no leakage, significant surface corrosion, or other anomalies. Ultrasonic thickness measurements made in 1980,1981, 1984, 1985, and 1990 showed no detectable thinning of the tank wall.

\section{Tank 43}

Tank 43 was placed in service in 1982. Examinations of $100 \%$ of the exterior of the primary vessel wall and the annulus have shown no leakage, significant surface corrosion, or other anomalies. Ultrasonic thickness measurements made in 1980, 1981, 1984, and 1985 showed no detectable thinning of the tank wall. 


\section{Tank 44}

Tank 44 was placed in service in 1982. Examinations of $100 \%$ of the exterior of the primary vessel wall and the annulus have shown no leakage, significant surface corrosion, or other anomalies. Ultrasonic thickness measurements made in 1980, 1981, and 1984 showed no detectable thinning of the tank wall.

\section{Tank 45}

Tank 45 was placed in service in 1982. Examinations of $100 \%$ of the exterior of the primary vessel wall and the annulus have shown no leakage, significant surface corrosion, or other anomalies. Ultrasonic thickness measurements made in 1980, 1981, and 1984 showed no detectable thinning of the tank wall.

\section{Tank 46}

Tank $\mathbf{4 6}$ was placed in service as an emergency spare tank in 1980. The tank has remained empty. Examinations of $100 \%$ of the exterior of the primary vessel wall and the annulus have shown no significant surface corrosion or other anomalies. Ultrasonic thickness measurements made in 1980, 1981, and 1984 showed no detectable thinning of the tank wall.

\section{Tank 47}

Tank 47 was placed in service in 1980. Examinations of $100 \%$ of the exterior of the primary vessel wall and the annulus have shown no leakage, significant surface corrosion, or other anomalies. Ultrasonic thickness measurements made in 1980, 1981, and 1984 showed no detectable thinning of the tank wall.

\section{Tank 48}

Tank 48 was placed in service in 1983. Examinations of $100 \%$ of the exterior of the primary vessel wall and the annulus have shown no leakage, significant surface corrosion, or other anomalies. Ultrasonic thickness measurements made in 1982, prior to placing the tank in service, provide reference measurements for the future.

\section{Tank 49}

Tank 49 was placed in service in 1983. Examinations of $100 \%$ of the exterior of the primary vessel wall and the annulus have shown no leakage, significant surface corrosion, or other anomalies. Ultrasonic thickness measurements made in 1982, prior to placing the tank in service, provide reference measurements for the future.

\section{Tank 50}

Tank 50 was placed in service in 1983. Examinations of $100 \%$ of the exterior of the primary vessel wall and the annulus have shown no leakage, significant surface corrosion, or other anomalies. Ultrasonic thickness measurements made in 1982, prior to placing the tank in service, provide reference measurements for the future.

\section{Tank 51}

Tank 51 was placed in service in 1986. Examinations of $100 \%$ of the exterior of the primary vessel wall and the annulus have shown no leakage, significant surface corrosion, or other anomalies. Ultrasonic thickness measurements made in 1982, prior to placing the tank in service, provide reference measurements for the future. 


\section{Appendix A-Waste Tanks at SRS}

Table 1. SRS Waste Tank Specifications

\begin{tabular}{|c|c|c|c|c|c|}
\hline Number & Location & Type & $\begin{array}{l}\text { Project } \\
\text { Number }\end{array}$ & $\begin{array}{l}\text { Construction } \\
\text { Perlod }\end{array}$ & $\begin{array}{c}\text { Type of } \\
\text { Construction* }\end{array}$ \\
\hline 1.8 & $\mathbf{F}$ & 1 & 8980 & $1951-1953$ & Double wall-cooled \\
\hline $9-12$ & H & I & 8980 & $1951-1953$ & Double wall-cooled \\
\hline 13.16 & H & u & $\begin{array}{c}8980 \\
\text { P.W.O. }\end{array}$ & 1955-1956 & Double wall-cooled \\
\hline $17-20$ & $\mathbf{F}$ & IV & 981031 & 1958 & Single wall-uncooled \\
\hline $21-24$ & H & IV & 981089 & 1962 & Single wall-uncooled \\
\hline 25.28 & $\mathbf{F}$ & III & $\begin{array}{l}951493 \\
(75-1-a)\end{array}$ & $1975-1978$ & Double wall-cooled \\
\hline 29.32 & H & III & 981232 & 1967.1970 & Double wall-cooled \\
\hline 33-34 & $\mathbf{F}$ & III & 950974 & 1969.1972 & Double wall-cooled \\
\hline $35-37$ & H & III & $\begin{array}{l}951463 \\
(74-1-a)\end{array}$ & $1974-1977$ & Double wall-cooled \\
\hline 38.43 & H & III & $\begin{array}{c}951618 \\
(76-8-a)\end{array}$ & $1976-1980$ & Double wall-cooled \\
\hline 44.47 & $\mathbf{F}$ & III & 951747 & $1977-1980$ & Double wall-cooled \\
\hline $48-51$ & H & aI & $\begin{array}{c}951828 \\
(78-18-b)\end{array}$ & 1978-1981 & Double wall-cooled \\
\hline
\end{tabular}

- Tanks 32 and 35 have removable, roof-supported cooling coils. Tanks 30, 33, and 34 have bottom-supported deployable cooling coils. Tanks 29 and 31 have some deployable and some close-packed cooling assemblies, all bottom supported. All other cooled tanks have permanently installed cooling coils, roof-supported in Type I and II and bottomsupported in Type III tanks. 
This page intentionally left blank. 


\section{Appendix B-Summary of 1993 Inspections}

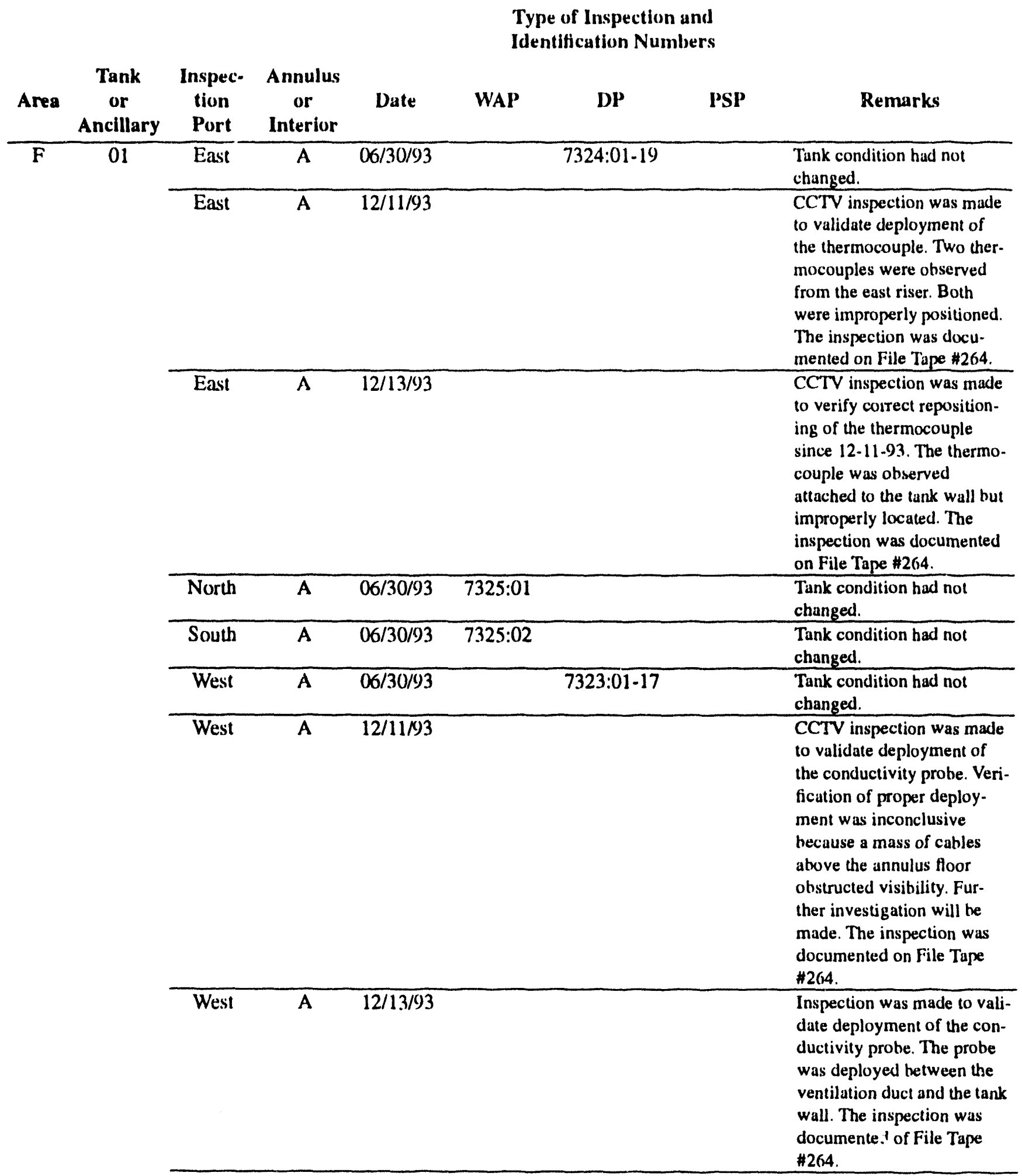

Note: The numbers listed under WAP, DP, and PSP identify photographs in the HLWE files.

WAP = wide angle photography; $\mathrm{DP}=$ direct photography; $\mathrm{PSP}=$ periscopic photography; $\mathrm{B}=$ diversion box; WLE = waste line encasement; $E V A P=$ evaporutor; $C T S=$ concentrate transfer system; $L D B=$ leak detection box; $P P=$ pump pit; $S S M H=$ storm sewer manhole. 
Type of Inspection and Identification Numbers

\begin{tabular}{|c|c|c|c|c|c|c|c|}
\hline Area & $\begin{array}{c}\text { Tank } \\
\text { or } \\
\text { Ancillary }\end{array}$ & $\begin{array}{l}\text { Inspec- } \\
\text { tion } \\
\text { Port }\end{array}$ & $\begin{array}{l}\text { Annulus } \\
\text { or } \\
\text { Interior }\end{array}$ & Date & WAP & PSP & Remarks \\
\hline \multirow[t]{2}{*}{$\bar{F}$} & 01 & Center & 1 & $01 / 20 / 93$ & $7174: 01-05$ & & $\begin{array}{l}\text { Inspection was made to doc- } \\
\text { ument conditions in the } \\
\text { tank after a discrepancy in } \\
\text { waste level measurements } \\
\text { was reported. }\end{array}$ \\
\hline & & Center & $I$ & $01 / 22 / 93$ & $7176: 01$ & & $\begin{array}{l}\text { Inspection was made to } \\
\text { investigate discrepancy in } \\
\text { waste level measurements. } \\
\text { Photographs revealed } \\
\text { uneven salt formations } \\
\text { beneath the steel tape riser } \\
\text { that could cause inconsistent } \\
\text { measurements. }\end{array}$ \\
\hline \multirow[t]{6}{*}{$F$} & 02 & East & $\bar{A}$ & $06 / 28 / 93$ & & $7318: 01-17$ & $\begin{array}{l}\text { Tank condition was normal. } \\
\text { Stuins and marks on the ven- } \\
\text { tilation duct were caused by } \\
\text { water inleakage. The ther- } \\
\text { mocouple was properly } \\
\text { positioned on the tank wall. }\end{array}$ \\
\hline & & North & $\bar{A}$ & $06 / 28 / 93$ & 7315:02 & & $\begin{array}{l}\text { Tank condition was normal. } \\
\text { The conductivity prohe was } \\
\text { properly deployed on the } \\
\text { annulus floor. }\end{array}$ \\
\hline & & South & $\mathrm{A}$ & $06 / 28 / 93$ & 7315:03 & & Tank condition was normal. \\
\hline & & South & $\bar{A}$ & $12 / 11 / 93$ & & & $\begin{array}{l}\text { CCTV inspection was made } \\
\text { to validate deployment of } \\
\text { the conductivity probe. The } \\
\text { probe wass properly } \\
\text { deployed on the annulus } \\
\text { floor between the ventilation } \\
\text { duct and the tank wall. The } \\
\text { inspection was documented } \\
\text { on File Tape } \$ 264 \text {. }\end{array}$ \\
\hline & & West & A & $06 / 28 / 93$ & & $7317: 01-17$ & Tank condition was normal. \\
\hline & & West & $\bar{A}$ & $06 / 28 / 93$ & $7315: 01$ & & Tank condition was normal. \\
\hline \multirow[t]{3}{*}{$\mathbf{F}$} & 03 & East & A & $06 / 30 / 93$ & & $7322: 01-18$ & $\begin{array}{l}\text { Tank condition was normal. } \\
\text { Stains and marks on the ven- } \\
\text { tilation duct were caused by } \\
\text { water inleakage. }\end{array}$ \\
\hline & & North & $A$ & $06 / 30 / 93$ & $7326: 01$ & & $\begin{array}{l}\text { Tank condition was normal. } \\
\text { The conductivity probe was } \\
\text { deployed on the annulus } \\
\text { foor between the ventilation } \\
\text { duct and the pan wall. }\end{array}$ \\
\hline & & South & A & $06 / 30 / 93$ & $7326: 02$ & & Tank condition was normal. \\
\hline
\end{tabular}


Type of Inspection and Identification Numbers

\begin{tabular}{|c|c|c|c|c|c|c|c|c|}
\hline Area & $\begin{array}{c}\text { Tank } \\
\text { or } \\
\text { Ancillary }\end{array}$ & $\begin{array}{c}\text { Inspec- } \\
\text { tion } \\
\text { Port }\end{array}$ & $\begin{array}{l}\text { Annulus } \\
\text { or } \\
\text { Interior }\end{array}$ & Date & WAP & DP & PSP & Remarks \\
\hline
\end{tabular}
to validate deployment of the conductivity probe. The probe was properly deployed on the annulus floor between the ventilation duct and the tank wall. The inspection was documented on File Tape \#264.

\begin{tabular}{lllll}
\hline West & A & $06 / 30 / 93$ & $7321: 01-20$ & $\begin{array}{l}\text { Tank condition was normal. } \\
\text { The thermocouple was prop- } \\
\text { erly positioned on the tank } \\
\text { wall. }\end{array}$ \\
\hline Center & I & $02 / 23 / 93$ & $7185: 01-07$ & $\begin{array}{l}\text { Inspection was made to } \\
\text { investigate discrepancy in }\end{array}$
\end{tabular}
waste level measurements. Photographs revealed the salt surface throughout the tank varied enough to cause inconsistent measurements.

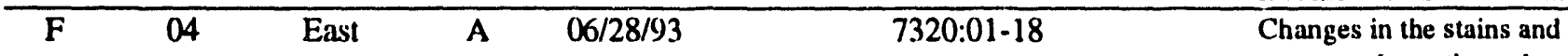
water marks on the tank wall and ventilation duct were caused by water inleakage. No other change was observed in the tank condition.

\begin{tabular}{llllll}
\hline East & A & $06 / 28 / 93$ & $7316: 02$ & $\begin{array}{l}\text { Tank condition was normal. } \\
\text { The thermocouple was prop- } \\
\text { erly positioned on the tank } \\
\text { wall. }\end{array}$ \\
\hline North & A & $06 / 28 / 93$ & $7316: 01$ & $\begin{array}{l}\text { Tank condition was normal. } \\
\text { The conductivity probe was } \\
\text { properly deployed on the } \\
\text { annulus floor. }\end{array}$ \\
\hline South & A & $06 / 28 / 93$ & $7316: 03$ & $\begin{array}{l}\text { Tank condition was normal. } \\
\text { The conductivity probe was } \\
\text { properly deployed on the } \\
\text { annulus floor. }\end{array}$ \\
\hline West & A & $06 / 28 / 93$ & & $\begin{array}{l}\text { Tank condition was normal. } \\
\text { Stains and marks on the ven- } \\
\text { tilation duct and annulus } \\
\text { floor were caused by water } \\
\text { iridivage. }\end{array}$ \\
\hline Center & Inspection was made to \\
& & & $7319: 01-17$ & $\begin{array}{l}\text { investigate discrepancy in } \\
\text { waste level measurements. } \\
\text { Photographs revealed the } \\
\text { waste surface was liquid and } \\
\text { should not cause a discrep- } \\
\text { ancy. }\end{array}$ \\
\hline
\end{tabular}


Type of Inspection and Identification Numbers

\begin{tabular}{|c|c|c|c|c|c|c|c|}
\hline Area & $\begin{array}{c}\text { Tank } \\
\text { or } \\
\text { Ancillary }\end{array}$ & $\begin{array}{c}\text { Inspec- } \\
\text { tion } \\
\text { Port }\end{array}$ & $\begin{array}{c}\text { Annulus } \\
\text { or } \\
\text { Interior }\end{array}$ & Date & WAP & I'SP' & Remarks \\
\hline \multirow[t]{6}{*}{ F } & \multirow[t]{6}{*}{05} & East & $A$ & $07 / 01 / 93$ & & $7330: 01-18$ & Tank condition was normal. \\
\hline & & North & $\mathrm{A}$ & $07 / 01 / 93$ & & $7331: 01-17$ & $\begin{array}{l}\text { Tank condition was normal. } \\
\text { Visual inspection validated } \\
\text { the conductivity probe was } \\
\text { properly deployed on the } \\
\text { annulus floor. }\end{array}$ \\
\hline & & South & A & $07 / 01 / 93$ & $7334: 01$ & & $\begin{array}{l}\text { Tank condition was normal. } \\
\text { The conductivity probe was } \\
\text { properly deployed on the } \\
\text { annulus floor. }\end{array}$ \\
\hline & & West & A & $07 / 01 / 93$ & 73334:02 & & Tank condition was normal. \\
\hline & & West & $\bar{A}$ & $12 / 11 / 93$ & & & $\begin{array}{l}\text { CCTV inspection was made } \\
\text { to validale deployment of } \\
\text { the thermocouple. The ther- } \\
\text { mocouple was properly } \\
\text { affixed near the hottom } \\
\text { girth weld. The inspection } \\
\text { was documented on File } \\
\text { Tape } \$ 263 \text {. }\end{array}$ \\
\hline & & Center & I & $03 / 01 / 93$ & $7201: 01-06$ & & $\begin{array}{l}\text { Inspection was made to } \\
\text { investigate discrepancy in } \\
\text { waste level measurements. } \\
\text { Photographs revealed salt } \\
\text { surface throughout the tank } \\
\text { varied enough to cause } \\
\text { inconsistent ineasurements. }\end{array}$ \\
\hline \multirow[t]{6}{*}{$\mathbf{F}$} & \multirow[t]{6}{*}{06} & East & A & $07 / 08 / 93$ & & $7332: 01-18$ & $\begin{array}{l}\text { Tank condition was normal. } \\
\text { The thennocouple was prop- } \\
\text { erly positioned on the tank } \\
\text { wall. }\end{array}$ \\
\hline & & North & A & $06 / 29 / 93$ & 7335:01 & & $\begin{array}{l}\text { Tank condition was normal. } \\
\text { The conductivity probe was } \\
\text { properly deployed on the } \\
\text { annulus floor. }\end{array}$ \\
\hline & & South & A & $(06 / 29 / 93$ & 733.3:02 & & $\begin{array}{l}\text { Tunk condition was normal. } \\
\text { The conductivity probe was } \\
\text { properly deployed on the } \\
\text { annulus floor. }\end{array}$ \\
\hline & & West & A & $06 / 29 / 93$ & 73335:03 & & Tank condition was normal. \\
\hline & & West & A & $07 / 15 / 93$ & & $7336: 01-17$ & Tank condition was normal. \\
\hline & & Center & I & $03 / 01 / 93$ & $7202: 01.04$ & & $\begin{array}{l}\text { Inspection was made to } \\
\text { investigate discrepancy in } \\
\text { waste level measurements. } \\
\text { Photographs revealed salt } \\
\text { surface throughout the tank } \\
\text { varied enough to cause } \\
\text { inconsistent ineasurements. }\end{array}$ \\
\hline
\end{tabular}


Type of Inspection and Identification Numbers

\begin{tabular}{|c|c|c|c|c|c|c|c|}
\hline Area & $\begin{array}{c}\text { Tank } \\
\text { or } \\
\text { Ancillary }\end{array}$ & $\begin{array}{l}\text { Inspec- } \\
\text { tion } \\
\text { Port }\end{array}$ & $\begin{array}{l}\text { Annulus } \\
\text { or } \\
\text { Interior }\end{array}$ & Date & WAP & PSP & Remarks \\
\hline \multirow[t]{4}{*}{$\mathrm{F}$} & \multirow[t]{4}{*}{07} & North & 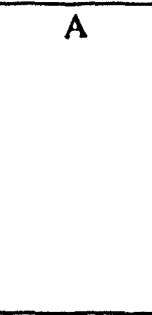 & $10 / 06 / 93$ & & $7457: 01-18$ & $\begin{array}{l}\text { Tunk condition was normul. } \\
\text { Stuins and marks observed } \\
\text { on the annulus floor were } \\
\text { caused hy water inleakage. } \\
\text { Visual inspection validated } \\
\text { the conductivity probe was } \\
\text { properly deployed on the } \\
\text { annulus floor. }\end{array}$ \\
\hline & & South & A & $07 / 08 / 93$ & $7333: 01$ & & $\begin{array}{l}\text { Tunk condition was normal. } \\
\text { The conductivity probe was } \\
\text { improperly deployed on the } \\
\text { annulus floor. }\end{array}$ \\
\hline & & West & A & $07 / 08 / 93$ & 7333:02 & & $\begin{array}{l}\text { Tank condition was normal. } \\
\text { The thernocouple was prop- } \\
\text { erly positioned on the tank } \\
\text { wall. }\end{array}$ \\
\hline & & 04 & 1 & $01 / 29 / 93$ & $7179: 01-04$ & & $\begin{array}{l}\text { Inspection was made to } \\
\text { check for obstruction that } \\
\text { would prevent the installa- } \\
\text { tion of a transfer pump. } \\
\text { Inspection revealed no } \\
\text { obstruction above the liquid } \\
\text { level. }\end{array}$ \\
\hline \multirow[t]{7}{*}{$\mathbf{F}$} & \multirow[t]{7}{*}{08} & East & $\mathbf{A}$ & $06 / 30 / 93$ & & 7328:01-17 & Tank condition was normal. \\
\hline & & East & A & $12 / 11 / 93$ & & & $\begin{array}{l}\text { CCTV inspection was made } \\
\text { to validate deployment of } \\
\text { the thermocouple. The ther- } \\
\text { mocouple was positioned } \\
\text { too high on the tank wall. } \\
\text { The inspection was docu- } \\
\text { mented on File Tap \#264. }\end{array}$ \\
\hline & & North & $\bar{A}$ & $06 / 29 / 93$ & 7327:01 & & $\begin{array}{l}\text { Tank condition was normal. } \\
\text { The conductivity probe was } \\
\text { deployed on the annulus } \\
\text { floor between the ventilation } \\
\text { duct and the pan wall. }\end{array}$ \\
\hline & & South & $\bar{A}$ & $06 / 29 / 93$ & 7327:02 & & $\begin{array}{l}\text { Tank condition was normal. } \\
\text { The conductivity probe was } \\
\text { deployed on the annulus } \\
\text { floor between the ventilation } \\
\text { duct and the pan wall. }\end{array}$ \\
\hline & & West & A & $06 / 29 / 93$ & $7327: 03$ & & Tank condition was normal. \\
\hline & & West & $\mathrm{A}$ & $06 / 30 / 93$ & & $7329: 01-20$ & Tank condition was normal. \\
\hline & & Center & $I$ & $01 / 29 / 93$ & $7178: 01-05$ & & $\begin{array}{l}\text { Inspection was made to } \\
\text { investigate discrepancy in } \\
\text { waste level measurements. } \\
\text { Inspection revealed the salt } \\
\text { surface throughout the tank } \\
\text { varied enough to cause } \\
\text { inconsistent measurements. }\end{array}$ \\
\hline
\end{tabular}


Type of Inspection and

Identification Numbers

$\begin{array}{ccccccc}\text { Tank } & \begin{array}{c}\text { Inspec- } \\ \text { or }\end{array} & \begin{array}{c}\text { Annulus } \\ \text { tion }\end{array} & \text { or } & \text { Date WAP } & \text { DP } & \text { PSP }\end{array}$

\begin{tabular}{|c|c|c|c|c|c|c|c|c|}
\hline Area & $\begin{array}{c}\text { or } \\
\text { Ancillary }\end{array}$ & $\begin{array}{l}\text { tion } \\
\text { Port }\end{array}$ & $\underset{\text { or }}{\text { orterior }}$ & Date & WAP' & DP & PSP & Remarks \\
\hline
\end{tabular}

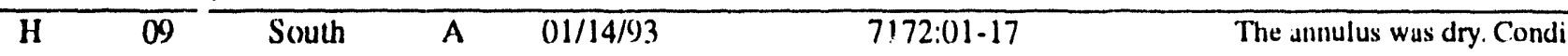
tion of the tank steel surface remained unchanged. No significant surface corrosion or other anomaly was ohserved.

\begin{tabular}{|c|c|c|c|}
\hline South & A & $04 / 02 / 93$ & $\begin{array}{l}\text { Visual inspection validated } \\
\text { the conductivity probe was } \\
\text { properly deployed on the } \\
\text { annulus floor. }\end{array}$ \\
\hline South & A & 7258:01-04 & $\begin{array}{l}\text { Tunk condition had not } \\
\text { changed. }\end{array}$ \\
\hline South & $\mathbf{A}$ & $05 / 05 / 93 \quad 7257: 01$ & $\begin{array}{l}\text { Tank condition had not } \\
\text { changed. }\end{array}$ \\
\hline South & A & $08 / 05 / 93$ & $\begin{array}{l}\text { After installation of a new } \\
\text { conductivity probe, a visual } \\
\text { inspection validated the } \\
\text { probe was properly } \\
\text { deployed on the annulus } \\
\text { floor. }\end{array}$ \\
\hline West & A & $04 / 19 / 93 \quad 7229: 01$ & $\begin{array}{l}\text { Tank condition had not } \\
\text { changed. }\end{array}$ \\
\hline West & A & $12 / 01 / 93$ & $\begin{array}{l}\text { Visual inspection validated } \\
\text { the conductivity probe was } \\
\text { properly deployed on the } \\
\text { annulus floor. }\end{array}$ \\
\hline West. & A & $12 / 01 / 93$ & $\begin{array}{l}\text { Visual inspection was made } \\
\text { to validate deployment of } \\
\text { the thermocouple. The ther- } \\
\text { mocouple was properly } \\
\text { positioned on the tank wall. }\end{array}$ \\
\hline Center & 1 & 03/22/93 7211:01-06 & $\begin{array}{l}\text { Inspection was made to } \\
\text { investigute discrepancy in } \\
\text { waste level measurements. } \\
\text { Photographs revealed salt } \\
\text { surface throughout the tunk } \\
\text { varied enough to cause } \\
\text { inconsistent measurements. }\end{array}$ \\
\hline
\end{tabular}


Type of Inspection and

Identification Numbers

Tank Inspec- Annulus

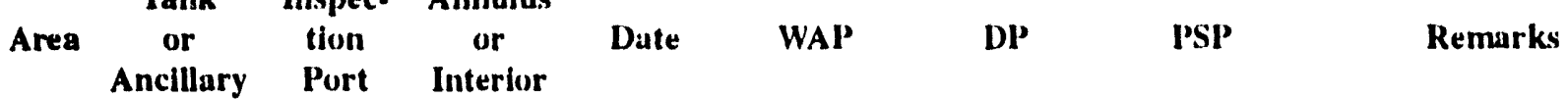

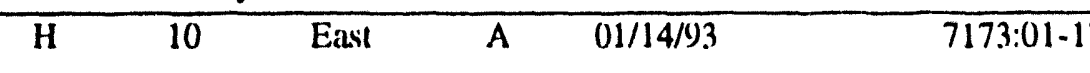
tion appeared unchanged since inspected on 03-05-91 except for the stuins and marks observed on the tunk wall and vertical duct. Changes in the stains and water marks were caused by the inleakuge of rain and gruund water. These changes have been documented hy periodic inspections made since 03-05-91. The thermocouple was properly affixed to the tunk wall near the hottom girth weld.

\begin{tabular}{|c|c|c|c|c|}
\hline East & 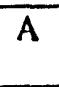 & $03 / 08 / 93$ & $7204: 01-04$ & $\begin{array}{l}\text { Tunk condition had not } \\
\text { changed. }\end{array}$ \\
\hline East & $\bar{A}$ & $03 / 19 / 93$ & $7210: 01-04$ & $\begin{array}{l}\text { Tank condition had not } \\
\text { changed. }\end{array}$ \\
\hline East & $\bar{A}$ & $04 / 02 / 93$ & $7213: 01-04$ & $\begin{array}{l}\text { Tunk condition had not } \\
\text { changed }\end{array}$ \\
\hline East & $\bar{A}$ & $04 / 08 / 93$ & $7220: 01-04$ & $\begin{array}{l}\text { Tank condition had not } \\
\text { changed. }\end{array}$ \\
\hline East & $\bar{A}$ & $05 / 05 / 93$ & $7260: 01-04$ & $\begin{array}{l}\text { Tank condition had not } \\
\text { changed. }\end{array}$ \\
\hline East & $\bar{A}$ & $06 / 23 / 93$ & $7314: 01-(14)$ & $\begin{array}{l}\text { Tunk condition had not } \\
\text { changed. }\end{array}$ \\
\hline East & $\bar{A}$ & $07 / 30 / 93$ & $7359: 01-03$ & $\begin{array}{l}\text { Tank condition had not } \\
\text { changed. }\end{array}$ \\
\hline East & $\mathrm{A}$ & $08 / 10 / 93$ & $7365: 01-(04$ & $\begin{array}{l}\text { Tank condition had not } \\
\text { changed. }\end{array}$ \\
\hline East & A & $0 x / 09 / 93$ & $7406: 01-04$ & $\begin{array}{l}\text { Tank condition had not } \\
\text { changed. }\end{array}$ \\
\hline East & $\mathrm{A}$ & $0(x) / 23 / 93$ & $7455: 01-04$ & $\begin{array}{l}\text { Tank condition had not } \\
\text { changed. }\end{array}$ \\
\hline East & $\bar{A}$ & $11 / 03 / 93$ & $7466: 01-05$ & $\begin{array}{l}\text { Tunk condition had not } \\
\text { changed. }\end{array}$ \\
\hline East & A & $12 / 01 / 93$ & & $\begin{array}{l}\text { Visual inspection validated } \\
\text { the conductivity probe was } \\
\text { properly deployed on the } \\
\text { annulus floor. }\end{array}$ \\
\hline East & $A$ & $12 / 02 / 93$ & $7475: 01-04$ & $\begin{array}{l}\text { Tunk condition had not } \\
\text { changed. }\end{array}$ \\
\hline North & $\mathrm{A}$ & $04 / 19 / 93$ & $7230: 02$ & $\begin{array}{l}\text { Tunk condition had not } \\
\text { changed. }\end{array}$ \\
\hline North & $A$ & $12 / 01 / 93$ & & $\begin{array}{l}\text { Visual inspection validated } \\
\text { the conductivity prohe was } \\
\text { properly deployed on the } \\
\text { annulus floor. }\end{array}$ \\
\hline
\end{tabular}


Type of Inspection and

Identification Numbers

\begin{tabular}{|c|c|c|c|c|c|c|c|}
\hline Area & $\begin{array}{c}\text { Tunk } \\
\text { or } \\
\text { Ancillary }\end{array}$ & $\begin{array}{l}\text { Inspec- } \\
\text { tlon } \\
\text { Port }\end{array}$ & $\begin{array}{l}\text { Annulus } \\
\text { or } \\
\text { Interior }\end{array}$ & Date & WAP & PSP & Remurks \\
\hline \multirow[t]{16}{*}{$\mathrm{H}$} & \multirow[t]{16}{*}{10} & West & $\mathrm{A}$ & $01 / 14 / 93$ & & $7171: 01-04$ & $\begin{array}{l}\text { Tank condition had not } \\
\text { changed. }\end{array}$ \\
\hline & & West & A & $02 / 23 / 93$ & & $7187: 01-04$ & $\begin{array}{l}\text { Tank condition had not } \\
\text { changed. }\end{array}$ \\
\hline & & West & A & $03 / 08 / 93$ & & $7203: 01-04$ & $\begin{array}{l}\text { Tank condition had not } \\
\text { changed. }\end{array}$ \\
\hline & & West & $A$ & $03 / 19 / 93$ & & $7209: 01-04$ & $\begin{array}{l}\text { Tank condition had not } \\
\text { changed. }\end{array}$ \\
\hline & & West & A & $04 / 02 / 93$ & & $7214: 01-04$ & $\begin{array}{l}\text { Water was observed in the } \\
\text { annulus after heavy rainfall. } \\
\text { ( } 4.4 \text { inches of rain fell dur- } \\
\text { ing the preceeding week.) }\end{array}$ \\
\hline & & West & A & $04 / 08 / 93$ & & 7219:01-(14 & No water was ohserved. \\
\hline & & West & A & $04 / 19 / 93$ & $7230: 01$ & & $\begin{array}{l}\text { Tank condition had not } \\
\text { changed. }\end{array}$ \\
\hline & & West & A & $0.5 / 05 / 93$ & & $7259:(01-(14$ & $\begin{array}{l}\text { Tank condition had not } \\
\text { changed. }\end{array}$ \\
\hline & & West & A & $06 / 23 / 93$ & & $7313: 01-(14$ & $\begin{array}{l}\text { Tank condition had not } \\
\text { changed. }\end{array}$ \\
\hline & & West & A & $07 / 30 / 93$ & & $7360: 01-(04$ & $\begin{array}{l}\text { Tank condition had not } \\
\text { changed. }\end{array}$ \\
\hline & & West & A & $08 / 06 / 43$ & & $7361: 01-04$ & $\begin{array}{l}\text { Tank condition had not } \\
\text { changed. }\end{array}$ \\
\hline & & West & A & $08 / 10 / 93$ & & $7366: 01-04$ & $\begin{array}{l}\text { Tank condition had not } \\
\text { changed. }\end{array}$ \\
\hline & & West & A & $09 / 09 / 93$ & & $7407: 01-04$ & $\begin{array}{l}\text { Tank condition had not } \\
\text { changed. }\end{array}$ \\
\hline & & West & A & $09 / 23 / 93$ & & $7456: 01-(14$ & $\begin{array}{l}\text { Tank condition had not } \\
\text { changed. }\end{array}$ \\
\hline & & West & A & $11 / 03 / 93$ & & $7465: 01-04$ & $\begin{array}{l}\text { Tank condition had not } \\
\text { changed. }\end{array}$ \\
\hline & & West & A & $12 / 02 / 93$ & & $7476: 01.04$ & $\begin{array}{l}\text { Tank condition had not } \\
\text { changed. }\end{array}$ \\
\hline \multirow[t]{2}{*}{$\mathrm{H}$} & \multirow[t]{2}{*}{11} & East & $\mathbf{A}$ & $01 / 14 / 93$ & & $7169: 01-18$ & $\begin{array}{l}\text { Inspection was made to look } \\
\text { for evidence of steam leak- } \\
\text { age into the unnulus since } \\
\text { there was indicution that the } \\
\text { steum preheater had failed. } \\
\text { No evidence of steam leak- } \\
\text { age into the annulus was } \\
\text { uhserved. However, the } \\
\text { annulus floor was wet when } \\
\text { inspected. Historically. } \\
\text { water has leaked into the } \\
\text { annulus during periods of } \\
\text { heavy rainfall like those that } \\
\text { occurred prior to this inspec- } \\
\text { tion. }\end{array}$ \\
\hline & & East & A & $04 / 19 / 93$ & $7231: 01$ & & $\begin{array}{l}\text { Tunk condition had not } \\
\text { changed. }\end{array}$ \\
\hline
\end{tabular}


Type of linspection and

Identificution Numbers

\begin{tabular}{|c|c|c|c|c|c|c|c|c|}
\hline Area & $\begin{array}{c}\text { Tunk } \\
\text { or } \\
\text { Ancillury }\end{array}$ & $\begin{array}{l}\text { Inspec- } \\
\text { tion } \\
\text { Port }\end{array}$ & $\begin{array}{l}\text { Annulus } \\
\text { or } \\
\text { Interior }\end{array}$ & Dute & WAP & DI' & PSP & Remurks \\
\hline \multirow[t]{4}{*}{$\mathrm{H}$} & 11 & North & $\mathrm{A}$ & $01 / 14 / 93$ & & $7168:(11-17$ & & $\begin{array}{l}\text { Inspection was inade to look } \\
\text { for evidence of stean leak- } \\
\text { age into the annulus since } \\
\text { there was indication that the } \\
\text { steann preheuter had failed. } \\
\text { No evidence of stean leak- } \\
\text { age into the annulus was } \\
\text { ohserved. The tank condi- } \\
\text { tion had not changed; how- } \\
\text { ever, the annulus floor was } \\
\text { wet when inspected. Histori- } \\
\text { cully, water has leaked into } \\
\text { the annulus during periods } \\
\text { of heavy rainfull like those } \\
\text { that occurred prior to this } \\
\text { inspection. }\end{array}$ \\
\hline & & North & $\bar{A}$ & $04 / 19 / 93$ & $7231: 02$ & & & $\begin{array}{l}\text { Tank condition had not } \\
\text { chunged. The conductivity } \\
\text { prohe was propurly } \\
\text { deployed in the annulus } \\
\text { floor. }\end{array}$ \\
\hline & & South & A & $01 / 14 / 93$ & & $7170: 01 \cdot 18$ & & $\begin{array}{l}\text { Inspection was made to look } \\
\text { for evidence of steam leak- } \\
\text { age into the annulus since } \\
\text { there was indication that the } \\
\text { steam preheater had failed. } \\
\text { No evidence of steam leak- } \\
\text { age into the annulus was } \\
\text { ohserved. The tunk condi- } \\
\text { tion had not changed; how- } \\
\text { ever, the annulus floor was } \\
\text { wet when inspected. Histori- } \\
\text { cally, water had leaked into } \\
\text { the annulus during periods } \\
\text { of heavy rainfall like those } \\
\text { that occurred prior to this } \\
\text { inspection. }\end{array}$ \\
\hline & & South & A & $01 / 14 / 93$ & & & & $\begin{array}{l}\text { Visual inspection was made } \\
\text { to validate deployment of } \\
\text { the conductivity probe. The } \\
\text { prohe was properly } \\
\text { deployed on the annulus } \\
\text { floor. }\end{array}$ \\
\hline
\end{tabular}


Type of Inspection and

Identification Numbers

\begin{tabular}{|c|c|c|c|c|c|c|c|c|}
\hline Area & $\begin{array}{c}\text { Tank } \\
\text { or } \\
\text { Ancillary }\end{array}$ & $\begin{array}{l}\text { Inspec. } \\
\text { tlon } \\
\text { Port }\end{array}$ & $\begin{array}{l}\text { Annulus } \\
\text { or } \\
\text { Interior }\end{array}$ & Date & WAP & DP & PSP & Remarks \\
\hline $\mathrm{H}$ & 11 & West & A & $01 / 14 / 93$ & & $7167: 01 \cdot 18$ & & $\begin{array}{l}\text { Inspection was made to look } \\
\text { for evidence of steam leak. } \\
\text { age into the annulus since } \\
\text { there was indication that the } \\
\text { stean preheater had failed. } \\
\text { No evidence of steam leak. }\end{array}$ \\
\hline
\end{tabular}

age into the annulus was

observed. The tank condi.

tion had not changed; how-

ever, the annulus floor was

wet when inspected. Histori-

cally, water had leaked into

the annulus during periods

of heavy rainfall like those

that occurred prior to this

inspection.

\begin{tabular}{|c|c|c|c|c|}
\hline West & $\bar{A}$ & $01 / 14 / 93$ & $7167: 01-18$ & $\begin{array}{l}\text { The thermocouple was prop- } \\
\text { erly positioned on the tank } \\
\text { wall. }\end{array}$ \\
\hline 06 & $I$ & $09 / 15 / 93$ & $7424: 01-03$ & $\begin{array}{l}\text { Photographs were made to } \\
\text { document jet deployment at }\end{array}$ \\
\hline
\end{tabular}

riser 7. A photograph

showed the jel extending

below the lank top.

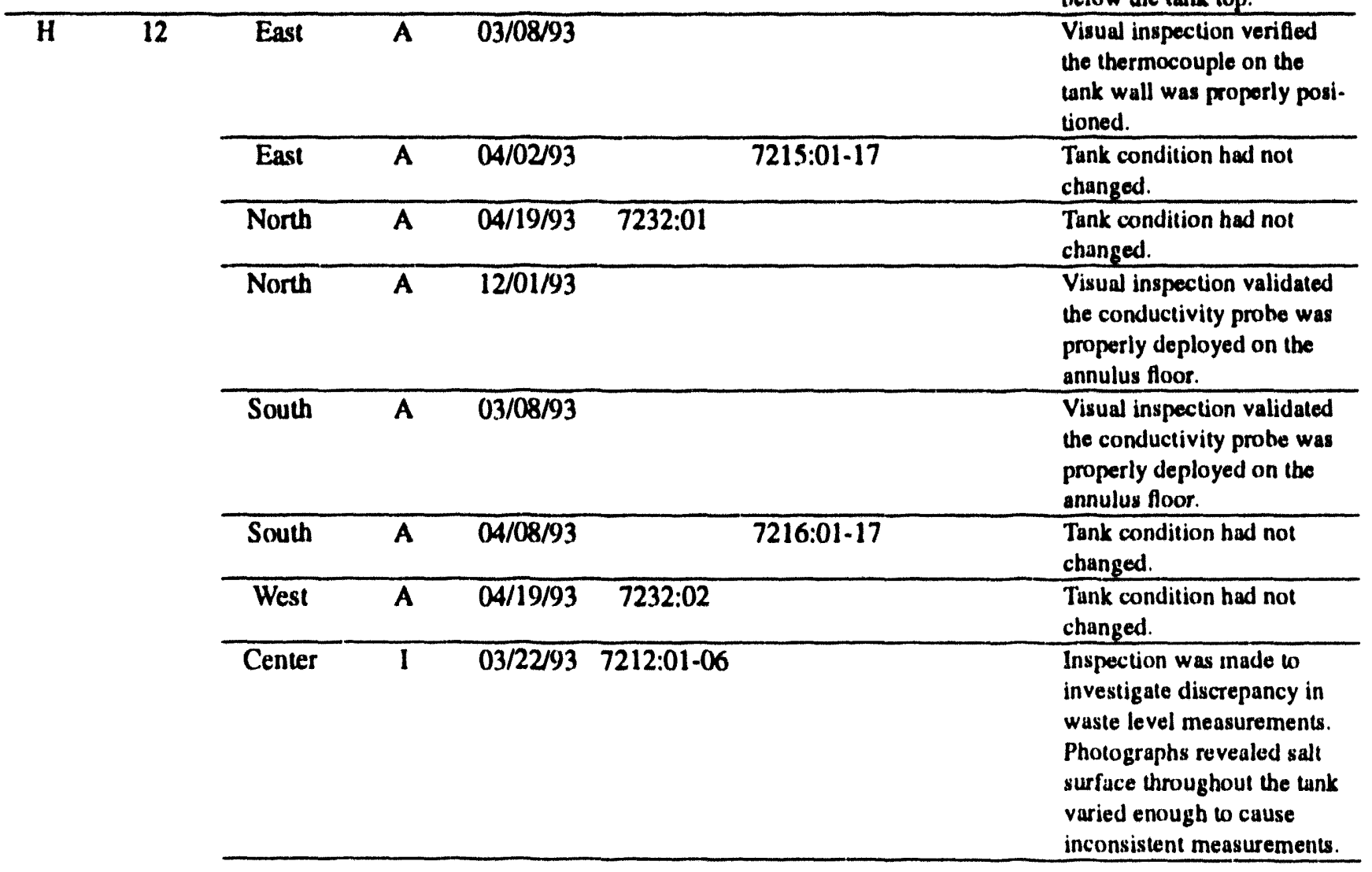


Type of Inspectlon and

Identilicutlon Numbers

Tunk Inspec- Annulus

\begin{tabular}{|c|c|c|c|c|c|c|c|}
\hline Area & $\begin{array}{c}\text { or } \\
\text { Ancillury }\end{array}$ & $\begin{array}{l}\text { tion } \\
\text { Port }\end{array}$ & $\begin{array}{c}\text { ur } \\
\text { Interior }\end{array}$ & Dute & WAI & PSI & Kemurks \\
\hline \multirow[t]{17}{*}{ HI } & 13 & 010 & $A$ & $04 / 28 / 93$ & $7267: 03$ & & $\begin{array}{l}\text { Tank condition had not } \\
\text { changed. }\end{array}$ \\
\hline & & 0.32 & A & $04 / 28 / 93$ & $7267:(14$ & & $\begin{array}{l}\text { Tunk condition had nol } \\
\text { changed. }\end{array}$ \\
\hline & & 055 & $\bar{A}$ & $04 / 28 / 93$ & $7267: 05$ & & $\begin{array}{l}\text { Tank condition had not } \\
\text { changed. }\end{array}$ \\
\hline & & 071 & A & $04 / 28 / 93$ & $7267: 166$ & & $\begin{array}{l}\text { Tank condition had not } \\
\text { changed. }\end{array}$ \\
\hline & & 107 & $\bar{A}$ & $08 / 18 / 93$ & $7368: 01.17$ & & $\begin{array}{l}\text { Tunk condition had not } \\
\text { changed. }\end{array}$ \\
\hline & & 151 & $A$ & $(14 / 28 / 9) ?$ & $7267: 07$ & & $\begin{array}{l}\text { Tunk condition had not } \\
\text { changed. }\end{array}$ \\
\hline & & 175 & $\Lambda$ & $08 / 18 / 93$ & $7364:(1) 1-17$ & & $\begin{array}{l}\text { Tunk condition had not } \\
\text { chunged. }\end{array}$ \\
\hline & & 2017 & $\bar{A}$ & $08 / 18 / 03$ & $7370:(01.17$ & & $\begin{array}{l}\text { Tank condition had not } \\
\text { changed. }\end{array}$ \\
\hline & & 228 & $A$ & $04 / 28 / 93$ & $7267: 08$ & & $\begin{array}{l}\text { Tink condition had not } \\
\text { changed. }\end{array}$ \\
\hline & & EiLvI & $\hat{A}$ & $0.3 / 08 / 9) 3$ & & & $\begin{array}{l}\text { Visual inspection verified } \\
\text { the thermocouple on the } \\
\text { lank wall was properly posi- } \\
\text { lioned. }\end{array}$ \\
\hline & & East & $\bar{A}$ & $08 / 26 / 93$ & $7388: 01-17$ & & $\begin{array}{l}\text { Tank condition had not } \\
\text { changed. }\end{array}$ \\
\hline & & North & $A$ & $04 / 28 / 93$ & $7267: 01$ & & $\begin{array}{l}\text { Tunk condition had not } \\
\text { changed. }\end{array}$ \\
\hline & & North & $\bar{A}$ & $08 / 26 / 93$ & & & $\begin{array}{l}\text { Visual inspection was made } \\
\text { to validale deployment of } \\
\text { the conductivity prohe. The } \\
\text { probe was properly } \\
\text { deployed on the annulus } \\
\text { Hoor. }\end{array}$ \\
\hline & & North & A & $12 / 01 / 93$ & & & $\begin{array}{l}\text { Visual inspection was made } \\
\text { to validate depluyment of } \\
\text { the thermocouple. The ther- } \\
\text { inucouple was properly } \\
\text { uffixed to the tank wall near } \\
\text { the hollom girth weld. }\end{array}$ \\
\hline & & South & A & $0.3 /(08 / 93$ & & & $\begin{array}{l}\text { Visual inspection validated } \\
\text { the conductivity protie was } \\
\text { propurly deployed on the } \\
\text { annulus floor. }\end{array}$ \\
\hline & & South & $\bar{A}$ & $(14 / 28 / 93$ & $7267: 02$ & & $\begin{array}{l}\text { Tank condition had not } \\
\text { changed. }\end{array}$ \\
\hline & & South & $\bar{A}$ & $12 / 01 / 93$ & & & $\begin{array}{l}\text { Visual inspection was made } \\
\text { to validate deployment of } \\
\text { the conductivity probe. The } \\
\text { probe was properly } \\
\text { deployed on the annulus } \\
\text { floor. }\end{array}$ \\
\hline
\end{tabular}


Type of Inspectlon und Identifleatlini Numbers

Tunk Inspec- Annulus

\begin{tabular}{|c|c|c|c|c|c|c|c|}
\hline Area & $\begin{array}{c}\text { or } \\
\text { Ancillary }\end{array}$ & $\begin{array}{l}\text { tlon } \\
\text { Port }\end{array}$ & $\begin{array}{c}\text { Interiur } \\
\text { Int }\end{array}$ & Dute & WAI & III' & l'sl' \\
\hline $\mathrm{H}$ & 13 & Went & $\bar{A}$ & $08 / 2(2 / 1) 3$ & & $7387:(11.17$ & \\
\hline
\end{tabular}
ink comdillon had not changed

Inspexcison was made to determine if un olsotruction was present that could inter. fere with real tape measure. ments. Pholographs re vealed no olistruction and that the waste surface was liquid throughout the tank

\begin{tabular}{|c|c|c|c|c|c|}
\hline \multirow[t]{9}{*}{14} & 013 & $A$ & $08 / 24 / 93$ & $7381:(11.17$ & $\begin{array}{l}\text { Salt mases had formed atop } \\
\text { the layer of leaked wasle in } \\
\text { the annulus. The inleakage } \\
\text { of rainwater had recontig. } \\
\text { ured the surfoce of the } \\
\text { waste. The lank condition } \\
\text { had mol changed. }\end{array}$ \\
\hline & 032 & $\mathbf{A}$ & $(04 / 29 / 93$ & $7268: 01$ & $\begin{array}{l}\text { Changes in the surface of the } \\
\text { dry leaked waste in the } \\
\text { annulus indicute water had } \\
\text { leaked in the annulus. The } \\
\text { tank condition had nol } \\
\text { changed. }\end{array}$ \\
\hline & 032 & $A$ & $08 / 20103$ & $7375: 01 \cdot(14$ & $\begin{array}{l}\text { Sult masses had formed alop } \\
\text { the layer of leaked waste in } \\
\text { the annulus. The inleakage } \\
\text { of rainwater had recontig. } \\
\text { ured the surface of the } \\
\text { waste. The tank condition } \\
\text { hod mol changed. }\end{array}$ \\
\hline & 06.5 & $A$ & $04 / 29 / 03$ & $7268: 02$ & $\begin{array}{l}\text { Changes itl the surface of the } \\
\text { dry leaked waste in the } \\
\text { unnulus indicate water had } \\
\text { leaked in the annulus. The } \\
\text { tank condition had not } \\
\text { changed. }\end{array}$ \\
\hline & 065 & $A$ & $08 / 2.5 / 93$ & $7383: 01-17$ & $\begin{array}{l}\text { Salt massex had formed ulop } \\
\text { the layer of leaked waste in } \\
\text { the annulus. The inleakuge } \\
\text { of rainwater had reconfig. } \\
\text { ured the surfuce of the } \\
\text { waste. The tank condition } \\
\text { had not changed. }\end{array}$ \\
\hline & 108 & $A$ & $(04 / 29 ! 9) 3$ & $7268: 03$ & $\begin{array}{l}\text { Tank condition had not } \\
\text { changed. }\end{array}$ \\
\hline & 108 & $A$ & $08 / 25 / 93$ & $7384: 01.17$ & $\begin{array}{l}\text { Tank condition had not } \\
\text { changed. }\end{array}$ \\
\hline & 118 & $\Lambda$ & $(14 / 20 / 03$ & $726 x:(14$ & $\begin{array}{l}\text { Tank condition had not } \\
\text { changed. }\end{array}$ \\
\hline & 118 & $\Lambda$ & $08 / 2.5 / 03$ & $738.5: 01-1.5$ & $\begin{array}{l}\text { Tink condition had not } \\
\text { changed. }\end{array}$ \\
\hline
\end{tabular}


Type of Inspection und Identificution Numbers

\begin{tabular}{|c|c|c|c|c|c|c|c|c|}
\hline Area & $\begin{array}{c}\text { Tunk } \\
\text { or } \\
\text { Ancillury }\end{array}$ & $\begin{array}{l}\text { Inspec- } \\
\text { thun } \\
\text { Port }\end{array}$ & $\begin{array}{c}\text { Ansulus } \\
\text { or } \\
\text { Interior }\end{array}$ & Dale & WAP & UP & l'sl' & Remarks \\
\hline \multirow[t]{10}{*}{$H$} & 14 & 125 & $A$ & $04 / 29 / 93$ & $7268: 05$ & & & $\begin{array}{l}\text { Tank condition had not } \\
\text { changed. }\end{array}$ \\
\hline & & 125 & 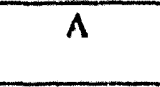 & $08 / 25 / 03$ & & $7386: 01 \cdot 16$ & & $\begin{array}{l}\text { Tunk condition had not } \\
\text { changed. }\end{array}$ \\
\hline & & 151 & $\Lambda$ & $08 / 24 / 93$ & & $7379: 01-17$ & & $\begin{array}{l}\text { Salt masses had formed atop } \\
\text { the layer of leaked waste in } \\
\text { the annulus. The inleakuge } \\
\text { of rainwater had reconfig- } \\
\text { ured the surface of the } \\
\text { waste. The tank condition } \\
\text { had not changed. }\end{array}$ \\
\hline & & 170 & $A$ & $08 / 24 / 93$ & & $7378: 01-16$ & & $\begin{array}{l}\text { Sult masses had formed atop } \\
\text { the layer of leaked waste in } \\
\text { the annulus. The inleakage } \\
\text { of rainwaler had reconfig- } \\
\text { ured the surface of the } \\
\text { waste. The tank condition } \\
\text { had not changed. }\end{array}$ \\
\hline & & 207 & $\bar{A}$ & $08 / 2(10) 3$ & & $7377: 01-18$ & & $\begin{array}{l}\text { Salt masses had formed atop } \\
\text { the layer of leaked waste in } \\
\text { the annulus. The inleakage } \\
\text { of rainwater had reconfig- } \\
\text { ured the surface of the } \\
\text { waste. The tank condition } \\
\text { had not changed. }\end{array}$ \\
\hline & & 235 & A & $08 / 20 / 93$ & & $7376: 01-16$ & & $\begin{array}{l}\text { Sal masses had formed atop } \\
\text { the layer of leaked waste in } \\
\text { the annulus. The inleakage } \\
\text { of rainwater had reconfig- } \\
\text { ured the surface of the } \\
\text { waste. The tank condition } \\
\text { had not changed. }\end{array}$ \\
\hline & & 2.35 & A & $(x) / 20 / 93$ & & $7433: 01-04$ & & $\begin{array}{l}\text { Tunk condition had not } \\
\text { changed. }\end{array}$ \\
\hline & & 23.5 & $\bar{A}$ & $10 / 08 / 93$ & & $74.59: 01-(14$ & & $\begin{array}{l}\text { Tank condition had not } \\
\text { changed. }\end{array}$ \\
\hline & & 235 & $A$ & $11 / 03 / 93$ & & $7464: 01-(04$ & & $\begin{array}{l}\text { Tunk condition had not } \\
\text { changed. }\end{array}$ \\
\hline & & 250 & A & $08 / 24 / 93$ & & $7382: 01-17$ & & $\begin{array}{l}\text { Sult masses had formed atop } \\
\text { the layer of leaked waste in } \\
\text { the annulus. The inleakage } \\
\text { of rainwater had reconfig. } \\
\text { ured surface of the waste. } \\
\text { The tank condition had not } \\
\text { changed. }\end{array}$ \\
\hline
\end{tabular}


Type of Inspection and Identification Numbers

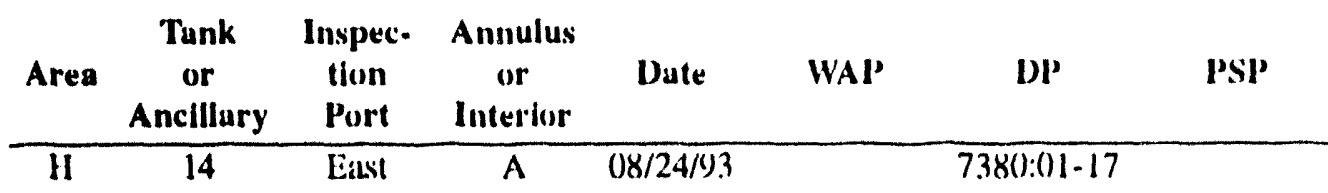

Sall masses had formed alop the layer of leaked waste in the annulus. The inleakage of rainwater had reconfigured the surface of the waste. The tank condition had not changed.

\begin{tabular}{|c|c|c|c|c|}
\hline Easit & $\bar{A}$ & $12 / 01 / 93$ & & $\begin{array}{l}\text { Visual inspection validated } \\
\text { the conductivity probe was } \\
\text { properly deployed on the } \\
\text { annulus floor. }\end{array}$ \\
\hline North & $\mathrm{A}$ & $11 / 29 / 93$ & $7142:(01-18$ & $\begin{array}{l}\text { Tank condition had not } \\
\text { changed. The thennocouple } \\
\text { was properly positioned on } \\
\text { the tank wall. }\end{array}$ \\
\hline North & $\bar{A}$ & $12 /() 1 / 93$ & & $\begin{array}{l}\text { Visual inspection validated } \\
\text { the conductivity probe was } \\
\text { properly deployed on the } \\
\text { annulus floor. }\end{array}$ \\
\hline 001 & 1 & $09 / 15 / 93$ & $7423: 01-(03$ & $\begin{array}{l}\text { Inspection was made to } \\
\text { determine the composition } \\
\text { of the waste surface. Photo- } \\
\text { graphs revealed the surface } \\
\text { was salts except for a small } \\
\text { pool of liquid on the salt } \\
\text { heneath the } 01 \text { riser. }\end{array}$ \\
\hline 010 & A & $09 / 01 / 93$ & $7398: 01 \cdot 17$ & $\begin{array}{l}\text { Tunk condition had not } \\
\text { changed. }\end{array}$ \\
\hline 032 & $\bar{A}$ & $04 / 28 / 133$ & $7265: 04$ & $\begin{array}{l}\text { Tank condition had not } \\
\text { changed. }\end{array}$ \\
\hline 071 & A & $04 / 28 / 93$ & $7265:(16$ & $\begin{array}{l}\text { Tank condition had not } \\
\text { changed. }\end{array}$ \\
\hline 107 & $\bar{A}$ & $08 / 31 / 93$ & $7395: 01-17$ & $\begin{array}{l}\text { Tank condition had not } \\
\text { changed. }\end{array}$ \\
\hline 117 & $\bar{A}$ & $08 / 31 / 93$ & $7396: 01-17$ & $\begin{array}{l}\text { Tank condition had not } \\
\text { changed. }\end{array}$ \\
\hline 137 & $A$ & $08 / 31 / 93$ & $7397: 01-17$ & $\begin{array}{l}\text { Tunk condition had not } \\
\text { changed. }\end{array}$ \\
\hline 171 & $A$ & $09 / 01 / 93$ & $7399: 01-17$ & $\begin{array}{l}\text { Tank condition had not } \\
\text { changed. }\end{array}$ \\
\hline 182 & $\bar{A}$ & $09 / 01 / 93$ & 740()$: 01-16$ & $\begin{array}{l}\text { Tank condition had not } \\
\text { changed. }\end{array}$ \\
\hline 207 & $\bar{A}$ & $(14 / 28 / 93$ & $7265: 07$ & $\begin{array}{l}\text { Tank condition had not } \\
\text { changed. }\end{array}$ \\
\hline 223 & $\bar{A}$ & $04 / 28 / 93$ & $726.5: 08$ & $\begin{array}{l}\text { Tank condition had not } \\
\text { changed. }\end{array}$ \\
\hline 242 & $A$ & $12 / 17 / 93$ & & $\begin{array}{l}\text { Visual inspection verified } \\
\text { the thermucouple on the } \\
\text { tank wall was properly posi- } \\
\text { tioned. }\end{array}$ \\
\hline
\end{tabular}


Type of Inspection and Identification Numbers

Tank Inspec- Annulus

\begin{tabular}{|c|c|c|c|c|c|c|c|}
\hline Area & $\begin{array}{c}\text { or } \\
\text { Ancillary }\end{array}$ & $\begin{array}{l}\text { tion } \\
\text { Port }\end{array}$ & $\begin{array}{c}\text { or } \\
\text { Interior }\end{array}$ & Dute & WAP & PSI' & Kemurks \\
\hline \multirow[t]{6}{*}{$\mathrm{H}$} & 15 & East & $A$ & $04 / 28 / 93$ & $726.5:(12$ & & $\begin{array}{l}\text { Tank condition had not } \\
\text { changed. }\end{array}$ \\
\hline & & North & A & $04 / 28 / 93$ & $7265: 01$ & & $\begin{array}{l}\text { Tank condition had not } \\
\text { changed. }\end{array}$ \\
\hline & & North & A & $09 / 03 / 93$ & & & $\begin{array}{l}\text { Visual inspection verified } \\
\text { the thermocouple on the } \\
\text { tank was properly posi- } \\
\text { tioned. }\end{array}$ \\
\hline & & South & A & $09 / 01 / 93$ & & & $\begin{array}{l}\text { Visual inspection validated } \\
\text { the conductivity probe was } \\
\text { properly deployed on the } \\
\text { annulus floor. }\end{array}$ \\
\hline & & South & $A$ & $09 / 03 / 93$ & $7401: 01-17$ & & $\begin{array}{l}\text { Tunk condition had not } \\
\text { changed. }\end{array}$ \\
\hline & & West & A & $04 / 28 / 93$ & $7265: 03$ & & $\begin{array}{l}\text { Tunk condition had not } \\
\text { changed. }\end{array}$ \\
\hline \multirow[t]{4}{*}{$\mathrm{H}$} & 16 & 03.5 & A & $08 / 26 / 93$ & $7391: 01-17$ & & $\begin{array}{l}\text { Changes in the water marks } \\
\text { and stains were caused by } \\
\text { condensate and humid con- } \\
\text { ditions that prevailed for a } \\
\text { short time after the preheater } \\
\text { failed on the annulus venti- } \\
\text { lation system. No other } \\
\text { change was observed in the } \\
\text { tank. }\end{array}$ \\
\hline & & 118 & A & $08 / 26 / 93$ & $7392: 01-17$ & & $\begin{array}{l}\text { Changes in the water marks } \\
\text { and stains were caused by } \\
\text { condensate and humid con- } \\
\text { ditions that prevailed for a } \\
\text { short after the preheater } \\
\text { failed on the annulus venti- } \\
\text { lation system. No other } \\
\text { change was observed in the } \\
\text { tank. }\end{array}$ \\
\hline & & 207 & $\bar{A}$ & $07 / 19 / 93$ & $7344: 01-05$ & & $\begin{array}{l}\text { Inspection made to investi- } \\
\text { gate an annulus leak detec. } \\
\text { tion alarm. The annulus was } \\
\text { dry when inspected. }\end{array}$ \\
\hline & & 207 & A & $08 / 26 / 93$ & $7389: 01-18$ & & $\begin{array}{l}\text { Changes in the water marks } \\
\text { and stains were caused by } \\
\text { condensate and humid con- } \\
\text { ditions that prevailed for a } \\
\text { short time after the preheater } \\
\text { failed on the annulus venti- } \\
\text { lation system. No other } \\
\text { change was observed in the } \\
\text { lank. }\end{array}$ \\
\hline
\end{tabular}


Type of Inspection and

Identification Numbers

\begin{tabular}{|c|c|c|c|c|c|c|c|c|}
\hline Area & $\begin{array}{c}\text { Tank } \\
\text { or } \\
\text { Ancillary }\end{array}$ & $\begin{array}{c}\text { Inspec- } \\
\text { tion } \\
\text { Port }\end{array}$ & $\begin{array}{c}\text { Annulus } \\
\text { or } \\
\text { Interior }\end{array}$ & Date & WAP & DP & PSP & Remarks \\
\hline \multirow[t]{5}{*}{$\mathbf{H}$} & \multirow[t]{5}{*}{16} & 262 & $A$ & $08 / 26 / 93$ & & $7390: 01-17$ & & $\begin{array}{l}\text { Changes in the water marks } \\
\text { and stains were caused by } \\
\text { condensate and humid con- } \\
\text { ditions that prevailed for a } \\
\text { short time after the preheater } \\
\text { failed on the annulus venti- } \\
\text { lation system. No other } \\
\text { change was observed in the } \\
\text { tank. }\end{array}$ \\
\hline & & East & A & $08 / 11 / 93$ & & $7367: 01-17$ & & $\begin{array}{l}\text { Changes in the stains and } \\
\text { deposits observed on the } \\
\text { secondary wall, the annulus } \\
\text { floor and duct were caused } \\
\text { hy water inleakage. No other } \\
\text { change was observed in the } \\
\text { tank. }\end{array}$ \\
\hline & & East & A & $08 / 27 / 93$ & & $7393: 01-17$ & & $\begin{array}{l}\text { Changes in the stains and } \\
\text { deposits observed on the } \\
\text { secondary wall, the annulus } \\
\text { floor and duct were caused } \\
\text { by watter inleakage. No other } \\
\text { change was observed in the } \\
\text { tank. }\end{array}$ \\
\hline & & East & A & $12 / 17 / 93$ & & & & $\begin{array}{l}\text { Visual inspection validated } \\
\text { the conductivity probe was } \\
\text { properly deployed on the } \\
\text { annulus floor. }\end{array}$ \\
\hline & & West & $\bar{A}$ & $08 / 27 / 93$ & & $7394: 01-17$ & & $\begin{array}{l}\text { Changes in the stains and } \\
\text { deposits observed on the } \\
\text { annulus floor and duct were } \\
\text { caused by water inleakage. } \\
\text { No other change was } \\
\text { observed in the tank. }\end{array}$ \\
\hline$F$ & 17 & East & I & $08 / 12 / 93$ & & & $7364: 01-35$ & Tank condition was normal. \\
\hline$F$ & 18 & Center & $I$ & $11 / 19 / 93$ & $7471: 01-12$ & & & Tunk condition was normal. \\
\hline \multirow[t]{3}{*}{$\bar{F}$} & \multirow[t]{3}{*}{19} & NE & I & $07 / 22 / 93$ & & & $7347: 01-36$ & Tank condition was normal. \\
\hline & & SW & I & $02 / 04 / 93$ & & & $7182: 01-05$ & $\begin{array}{l}\text { Inspection was made to } \\
\text { munitor a spot that was wet } \\
\text { when observed on } 12-08- \\
92 \text {. The wet area was on the } \\
\text { west wall approximately } 317 \\
\text { inches ahove the tank bot- } \\
\text { tom. Photographs revealed } \\
\text { U.st the area was damp. }\end{array}$ \\
\hline & & SW & I & $03 / 10 / 93$ & & & $7241: 01-04$ & $\begin{array}{l}\text { Inspection was made to } \\
\text { monitor the area observed } \\
\text { wet on 12-08-92. Photo- } \\
\text { graphs revealed that the } \\
\text { area was dry. }\end{array}$ \\
\hline
\end{tabular}


Type of Inspection and

Identification Numbers

\begin{tabular}{|c|c|c|c|c|c|c|c|c|}
\hline Area & $\begin{array}{c}\text { Tank } \\
\text { or } \\
\text { Ancillary }\end{array}$ & $\begin{array}{l}\text { Inspec- } \\
\text { tion } \\
\text { Port }\end{array}$ & $\begin{array}{l}\text { Annulus } \\
\text { or } \\
\text { Interior }\end{array}$ & Dute & WAP & DP & PSP & Remarks \\
\hline \multirow[t]{4}{*}{$F$} & 19 & SW & $I$ & $03 / 29 / 93$ & & & $7217: 01-06$ & $\begin{array}{l}\text { Inspection was made to } \\
\text { monitor the area observed } \\
\text { wet on } 12-08-92 \text {. Photo- } \\
\text { graphs revealed that the } \\
\text { area was dry. }\end{array}$ \\
\hline & & SW & 1 & $04 / 02 / 93$ & & & $7218: 01-08$ & $\begin{array}{l}\text { Inspection was made to } \\
\text { monitor the area observed } \\
\text { wet on 12-08-92. Photo- } \\
\text { graphs revealed that the } \\
\text { area was dry. }\end{array}$ \\
\hline & & SW & $I$ & $04 / 22 / 93$ & & & $7242: 01-02$ & $\begin{array}{l}\text { Inspection was made to } \\
\text { monitor the area observed } \\
\text { wet on } 12-08-92 \text {. Photo- } \\
\text { graphs revealed the wall was } \\
\text { dry and the surface appeared } \\
\text { normal. }\end{array}$ \\
\hline & & SW & I & $07 / 22 / 93$ & & & $7346: 01-37$ & Tunk condition was normal. \\
\hline $\mathbf{F}$ & 20 & SW & 1 & $08 / 05 / 93$ & & & $7358: 01-46$ & $\begin{array}{l}\text { Tunk condition had not } \\
\text { changed. }\end{array}$ \\
\hline $\mathbf{H}$ & 21 & NE: & 1 & $10 / 22 / 93$ & & & $7461: 01-48$ & Tank condition was normal. \\
\hline $\mathrm{H}$ & 22 & $\mathrm{NE}$ & I & $11 / 02 / 93$ & & & $7467: 01-48$ & Tank condition was normal. \\
\hline $\mathrm{H}$ & 23 & SW & $I$ & $10 / 14 / 93$ & & & $7460: 01-24$ & Tank condition was normal. \\
\hline $\mathrm{H}$ & 24 & SW & $I$ & $10 / 06 / 93$ & & & $7462: 01-46$ & Tank condition was normal. \\
\hline \multirow[t]{16}{*}{$\mathrm{F}$} & 25 & A-01 & A & $07 / 15 / 93$ & 7337:01 & & & Tank condition was normal. \\
\hline & & A.02 & $\mathrm{A}$ & $07 / 15 / 93$ & $7337: 02$ & & & $\begin{array}{l}\text { Tank condition was normal. } \\
\text { The conductivity probe was } \\
\text { properly deployed on the } \\
\text { annulus floor. }\end{array}$ \\
\hline & & A.03 & A & $07 / 15 / 93$ & $7337: 03$ & & & $\begin{array}{l}\text { Tank condition was normal. } \\
\text { The cunductivity probe was } \\
\text { properly deployed on the } \\
\text { annulus floor. }\end{array}$ \\
\hline & & A-04 & A & $07 / 15 / 93$ & $7337: 04$ & & & $\begin{array}{l}\text { Tank condition was normal. } \\
\text { The conductivity probe was } \\
\text { properly deployed on the } \\
\text { annulus floor. }\end{array}$ \\
\hline & & P.01 & A & $07 / 20 / 93$ & & $7362: 01-23$ & & Tank condition was normal. \\
\hline & & P.01 & A & $08 / 18 / 93$ & & $7373: 01-25$ & & Tank condition was normal. \\
\hline & & $\mathrm{P}-02$ & A & $08 / 18 / 93$ & & $7371: 01-25$ & & Tank condition was normal. \\
\hline & & P.03 & A & $07 / 15 / 93$ & 7337:05 & & & Tank condition was normal. \\
\hline & & P-04 & A & $07 / 15 / 93$ & 7337:06 & & & Tank condition was normal. \\
\hline & & P.05 & A & $07 / 15 / 93$ & 7337:07 & & & Tank condition was normal. \\
\hline & & P.06 & A & $07 / 1.5 / 93$ & 7337:08 & & & Tank condition was normal. \\
\hline & & P.07 & A & $07 / 26 / 93$ & & $7350: 01-25$ & & Tank condition was normal. \\
\hline & & P-08 & A & $07 / 26 / 93$ & & $73.51: 01-25$ & & Tunk condition was normal. \\
\hline & & P.09 & $A$ & $08 / 20 / 93$ & & $7374: 01-25$ & & Tank condition was normal. \\
\hline & & P-10 & A & $07 / 15 / 93$ & 7337:09 & & & Tunk condition was normal. \\
\hline & & $\mathrm{P}-11$ & $A$ & $07 / 1.5 / 93$ & $7337: 10$ & & & Tunk condition was normal. \\
\hline
\end{tabular}


Type of Inspection and

Identification Numbers

\begin{tabular}{|c|c|c|c|c|c|c|c|}
\hline Area & $\begin{array}{l}\text { Tank } \\
\text { or } \\
\text { Ancillary }\end{array}$ & $\begin{array}{l}\text { Inspec- } \\
\text { tion } \\
\text { Port }\end{array}$ & $\begin{array}{l}\text { Annulus } \\
\text { or } \\
\text { Interior }\end{array}$ & Date & WAP & PSP & Remarks \\
\hline \multirow[t]{3}{*}{$\mathbf{F}$} & 25 & P-12 & $\mathrm{A}$ & $07 / 15 / 93$ & $7337: 11$ & & Tank condition was normal. \\
\hline & & P.13 & $\mathrm{A}$ & $07 / 15 / 93$ & $7337: 12$ & & Tank condition was normal. \\
\hline & & P.14 & A & $07 / 15 / 93$ & $7337: 13$ & & Tank condition was normal. \\
\hline \multirow[t]{19}{*}{$F$} & 26 & A-01 & $\mathrm{A}$ & $07 / 15 / 93$ & 7338:01 & & Tank condition was normal. \\
\hline & & A-02 & A & $07 / 15 / 93$ & $7338: 02$ & & $\begin{array}{l}\text { Tank condition was normal. } \\
\text { The conductivity prote was } \\
\text { properly deployed on the } \\
\text { annulus floor. }\end{array}$ \\
\hline & & A-03 & A & $07 / 15 / 93$ & $7338: 03$ & & $\begin{array}{l}\text { Tank condition was normal. } \\
\text { The conductivity probe was } \\
\text { properly deployed on the } \\
\text { annulus floor. }\end{array}$ \\
\hline & & A. 04 & A & $07 / 15 / 93$ & $7338: 04$ & & $\begin{array}{l}\text { Tank condition was normal. } \\
\text { The conductivity prote was } \\
\text { properly deployed on the } \\
\text { annulus floor. }\end{array}$ \\
\hline & & P-01 & $\mathrm{A}$ & $07 / 15 / 93$ & $7338: 05$ & & Tank condition was norınal. \\
\hline & & P.01 & $\bar{A}$ & $07 / 16 / 93$ & & $7339: 01-25$ & Tank condition was normal. \\
\hline & & P-02 & $A$ & $07 / 1.5 / 93$ & $73.38:(16$ & & Tank condition was normal. \\
\hline & & P.03 & $\bar{A}$ & $07 / 26 / 93$ & & $7349: 01-25$ & Tank condition was normal. \\
\hline & & P.04 & $\bar{A}$ & $07 / 26 / 93$ & & $7352: 01.25$ & Tank condition was normal. \\
\hline & & P.05 & $\mathrm{A}$ & $07 / 15 / 93$ & $73.38: 08$ & & Tank condition was normal. \\
\hline & & P-06 & A & $07 / 15 / 93$ & $7338:(09)$ & & Tank condition was normal. \\
\hline & & P.07 & $\bar{A}$ & $07 / 1.5 / 93$ & $7338: 07$ & & Tank condition was normal. \\
\hline & & P.08 & $\bar{A}$ & $07 / 15 / 93$ & $7338: 11$ & & Tunk condition was normal. \\
\hline & & $P-(0)$ & $\bar{A}$ & $07 / 1.5 / 93$ & $7338: 12$ & & Tank condition was normal. \\
\hline & & P.10 & A & $07 / 26 / 93$ & & 7353:01-25 & Tank condition was normal. \\
\hline & & P-11 & $\mathrm{A}$ & $07 / 26 / 93$ & & $7354: 01-25$ & Tank condition was normal. \\
\hline & & P-12 & $\bar{A}$ & $07 / 15 / 93$ & $73.38: 13$ & & Tank condition was normal. \\
\hline & & P-13 & $\mathrm{A}$ & $07 / 15 / 93$ & $7338: 14$ & & Tunk condition was normal. \\
\hline & & P-14 & $\bar{A}$ & $07 / 1.5 / 93$ & $73.38: 15$ & & Tank condition was normal. \\
\hline \multirow[t]{7}{*}{$\bar{F}$} & 27 & A-01 & $\mathrm{A}$ & $07 / 16 / 93$ & 7345:01 & & Tunk condition was normal. \\
\hline & & A-02 & $\mathrm{A}$ & $07 / 16 / 93$ & $7345: 02$ & & $\begin{array}{l}\text { Tank condition was normal. } \\
\text { The conductivity probe was } \\
\text { properly deployed on the } \\
\text { annulus thoor. }\end{array}$ \\
\hline & & A-03 & $\bar{A}$ & $07 / 16 / 93$ & $7345: 03$ & & $\begin{array}{l}\text { Tank condition was normal. } \\
\text { The conductivity probe was } \\
\text { properly deployed on the } \\
\text { annulus floor. }\end{array}$ \\
\hline & & A-04 & $A$ & $07 / 16 / 93$ & $7345: 04$ & & $\begin{array}{l}\text { Tank condition was normal. } \\
\text { The conductivity probe was } \\
\text { properly deployed on the } \\
\text { annulus floor. }\end{array}$ \\
\hline & & P-01 & $\mathrm{A}$ & $07 / 16 / 93$ & & $7339: 01-25$ & Tank condition was normal. \\
\hline & & $\mathrm{P}-02$ & $A$ & $07 / 16 / 93$ & & $7340: 01-25$ & Tank condition was normal. \\
\hline & & P. 03 & $A$ & $07 / 16 / 93$ & $7345: 0.5$ & & Tank condition was normal. \\
\hline
\end{tabular}


Type of Inspection and

Identification Numbers

\begin{tabular}{|c|c|c|c|c|c|c|c|}
\hline Area & $\begin{array}{c}\text { Tank } \\
\text { or } \\
\text { Ancillary }\end{array}$ & $\begin{array}{l}\text { Inspec- } \\
\text { tion } \\
\text { Port }\end{array}$ & $\begin{array}{c}\text { Annulus } \\
\text { or } \\
\text { Interior }\end{array}$ & Date & WAP & I'SP' & Remarks \\
\hline \multirow[t]{11}{*}{$\mathrm{F}$} & 27 & P. 04 & $\mathrm{~A}$ & $07 / 16 / 93$ & 7345:06 & & Tank condition was normal. \\
\hline & & P.05 & $\mathrm{A}$ & $07 / 16 / 93$ & 7345:07 & & Tank condition was normal. \\
\hline & & P.06 & $\mathrm{A}$ & $07 / 16 / 93$ & 7345:08 & & Tunk condition was normal. \\
\hline & & P-07 & A & $07 / 16 / 93$ & & $7341: 01-25$ & Tunk condition was normal. \\
\hline & & P-08 & $\mathrm{A}$ & $07 / 16 / 93$ & & $7342: 01-25$ & Tank condition was normal. \\
\hline & & P.09 & A & $07 / 16 / 93$ & & $7343: 01-24$ & Tank condition was normal. \\
\hline & & P.10 & $\bar{A}$ & $07 / 16 / 93$ & $7345: 09$ & & Tank condition was normal. \\
\hline & & P-11 & $\mathrm{A}$ & $07 / 16 / 93$ & $7345: 10$ & & Tank condition was normal. \\
\hline & & P-12 & A & $07 / 16 / 93$ & $7345: 11$ & & Tank condition was normal. \\
\hline & & P-13 & $\bar{A}$ & $07 / 16 / 93$ & $7345: 12$ & & Tunk condition was normal. \\
\hline & & P-14 & $\mathrm{A}$ & $07 / 16 / 93$ & $7345: 13$ & & Tank condition was normal. \\
\hline \multirow[t]{18}{*}{$\mathbf{F}$} & 28 & A-01 & A & $01 / 25 / 93$ & $7177: 14$ & & Tank condition was normal. \\
\hline & & A. 02 & A & $01 / 25 / 93$ & $7177: 05$ & & $\begin{array}{l}\text { Tunk condition was normal. } \\
\text { The conductivity probe was } \\
\text { properly deployed on the } \\
\text { annulus floor. }\end{array}$ \\
\hline & & A-03 & A & $01 / 25 / 93$ & 7177:08 & & $\begin{array}{l}\text { Tank condition was normal. } \\
\text { The conductivity probe was } \\
\text { properly deployed on the } \\
\text { annulus floor. }\end{array}$ \\
\hline & & A. 04 & A & $01 / 2.5 / 93$ & $7177: 11$ & & $\begin{array}{l}\text { Tank condition was normal. } \\
\text { The conductivity probe was } \\
\text { properly deployed on the } \\
\text { annulus floor. }\end{array}$ \\
\hline & & P-01 & A & $01 / 25 / 93$ & $7177: 01$ & & Tank condition was normal. \\
\hline & & P.02 & $\mathrm{A}$ & $01 / 25 / 93$ & $7177: 02$ & & Tunk condition was normal. \\
\hline & & P.03 & A & $07 / 27 / 93$ & & 7355:01-25 & Tank condition was normal. \\
\hline & & P-(04 & $\mathrm{A}$ & $01 / 25 / 93$ & 7177:03 & & Tank condition was normal. \\
\hline & & P.05 & A & $01 / 25 / 93$ & $7177: 04$ & & Tank condition was normal. \\
\hline & & P.06 & $A$ & $07 / 27 / 93$ & & $7356: 01-25$ & Tank condition was normal. \\
\hline & & P.07 & $A$ & $01 / 25 / 93$ & $7177: 06$ & & Tunk condition was normal. \\
\hline & & P-08 & $\mathrm{A}$ & $07 / 27 / 93$ & & $7357: 01-24$ & Tank condition was normal. \\
\hline & & P-09 & A & $01 / 2.5 / 93$ & 7177:07 & & Tank condition was normal. \\
\hline & & P-10 & $\mathbf{A}$ & $01 / 25 / 93$ & 7177:09 & & Tank condition was normal. \\
\hline & & P-11 & $\mathrm{A}$ & $01 / 25 / 93$ & $7177: 10$ & & Tunk condition was normal. \\
\hline & & $\mathrm{P}-12$ & A & $08 / 18 / 93$ & & $7372: 01-25$ & Tunk condition was normal. \\
\hline & & P-13 & $A$ & $01 / 25 / 93$ & $7177: 12$ & & Tunk condition was normal. \\
\hline & & P-14 & A & $01 / 25 / 93$ & 7177:13 & & Tank condition was normal. \\
\hline \multirow[t]{2}{*}{ H } & 29 & A.01 & $\bar{A}$ & $03 / 09 / 93$ & $7205: 01$ & & $\begin{array}{l}\text { Tunk condition was normal. } \\
\text { The conductivity probe was } \\
\text { properly deployed on the } \\
\text { annulus floor. }\end{array}$ \\
\hline & & $\mathrm{A}-02$ & A & $04 / 21 / 93$ & $7205: 13$ & & $\begin{array}{l}\text { Tank condition was normal. } \\
\text { An absorhent wipe was } \\
\text { observed on the annulus } \\
\text { floor. }\end{array}$ \\
\hline
\end{tabular}


Type of Inspection and

Identification Numbers

\begin{tabular}{|c|c|c|c|c|c|c|}
\hline Area & $\begin{array}{c}\text { Tank } \\
\text { or } \\
\text { Ancillary }\end{array}$ & $\begin{array}{l}\text { Inspec- } \\
\text { tiun } \\
\text { Port }\end{array}$ & $\begin{array}{l}\text { Annulus } \\
\text { or } \\
\text { Interior }\end{array}$ & Date & WAP & DP \\
\hline $\mathrm{H}$ & 29 & $\mathrm{~A}-02$ & $A$ & $2 / 02 / 93$ & & \\
\hline
\end{tabular}

'SP'

Remarks

Visual inspection validated the conductivity probe was properly deployed on the annulus floor.

\begin{tabular}{llll}
\hline A-03 & A & $03 / 09 / 93$ & $7205: 02$ \\
\hline A-0.4 & A & $03 /(\times) / 93$ & $7205: 03$
\end{tabular}

Tank condition was normal. Stains and marks observed on the unnulus floor were caused by water inleakage. Tank condition was normal. The probe was properly deployed on the annulus floor. The thermocouple was properly positioned on the tank wall.

\begin{tabular}{llllll}
\hline P-01 & A & $03 /(x) / 93$ & $7205: 04$ & & Tank condition was normal. \\
\hline P-02 & A & $05 /(05 / 93$ & & $7244: 01-25$ & Tank condition was normal. \\
\hline P-03 & A & $03 /(0) / 93$ & $7205: 05$ & & Tank condition was normal. \\
\hline P-04 & A & $03 /(09 / 93$ & $7205: 06$ & & Tank condition was normal. \\
\hline P-05 & A & $05 /(03 / 93$ & & $7245: 01-25$ & Tank condition was normal. \\
\hline P-06 & A & $03 /(09 / 93$ & $7205: 07$ & & Tank condition was normal. \\
\hline P-07 & A & $03 /(09 / 93$ & $7205: 08$ & & Tank condition was normal. \\
& & & & Stains and marks observed
\end{tabular}
on the secondary steel wall were caused hy water inleakage. Recent excavation made adjacent to the tank evidently allowed rainwater to enter the annulus where lines helow grade penetrate the annulus near $\mathbf{P}$. 07. The annulus was dry when inspected.

\begin{tabular}{|c|c|c|c|c|}
\hline P.08 & $\mathrm{A}$ & $05 / 03 / 93$ & $7246: 01-25$ & Tunk condition was normul. \\
\hline P-(0) & A & $0.3 /(x) / 93$ & $7205: 09$ & Tunk condition was normal. \\
\hline P-10 & $A$ & $03 /(x) / 93$ & $7205: 10$ & Tunk condition was normal. \\
\hline P-11 & $\bar{A}$ & $0.3 /(x) / 9.3$ & $7205: 11$ & Tank condition was normal. \\
\hline P.11 & $A$ & $0.5 / 03 / 93$ & $7247: 01-2.5$ & Tank condition was normal. \\
\hline P.12 & $\bar{A}$ & $0.5 /(24 / 93$ & $7248: 01-25$ & $\begin{array}{l}\text { Tank cundition was normal. } \\
\text { Stains and marks observed }\end{array}$ \\
\hline
\end{tabular}
on the annulus wall and duct were caused hy water inleakage.

\begin{tabular}{|c|c|c|c|c|c|c|}
\hline & & & & & \multirow[b]{2}{*}{ Tank condition was normal. } \\
\hline & & P-13 & A & $03 / 09 / 93$ & $7205: 12$ & \\
\hline & & P-14 & $\mathrm{A}$ & $0.5 / 03 / 93$ & $7249: 01-25$ & Tank condition was normal. \\
\hline \multirow[t]{2}{*}{$\mathrm{H}$} & 30 & A.01 & A & $03 / 11 / 93$ & $72(24: 01$ & $\begin{array}{l}\text { Tank condition was normal. } \\
\text { The conductivity prohe was } \\
\text { properly deployed on the } \\
\text { annulus floor. }\end{array}$ \\
\hline & & $\mathrm{A}-02$ & A & $04 / 21 / 93$ & $7204: 13$ & Tank condition was normal. \\
\hline
\end{tabular}


Type of Inspection and Identification Numbers

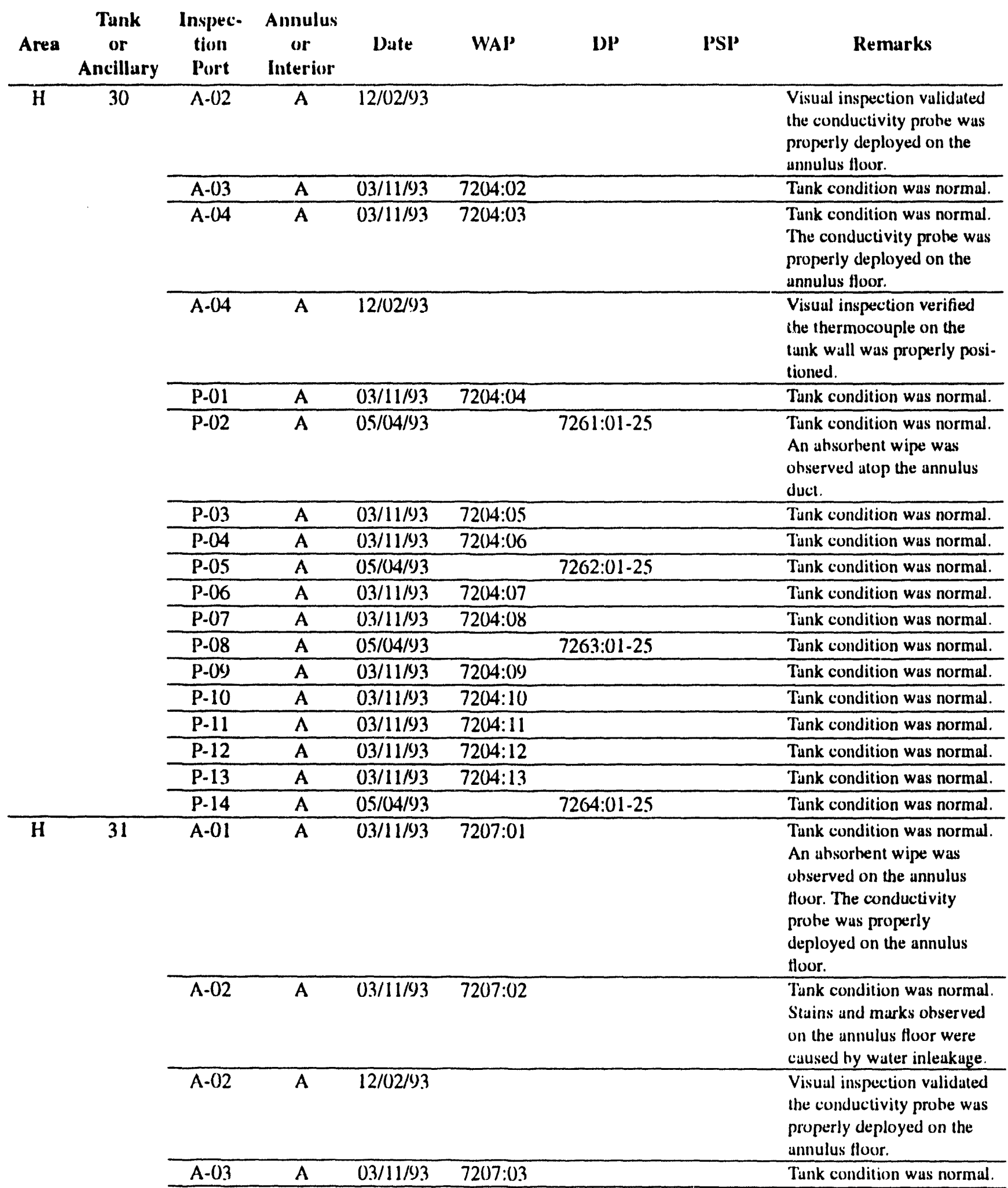


Type of Inspection and

Identification Numbers

$\begin{array}{ccccccc}\text { Area } & \begin{array}{c}\text { Tank } \\ \text { or } \\ \text { Ancillary }\end{array} & \begin{array}{c}\text { Inspec- } \\ \text { tion } \\ \text { Port }\end{array} & \begin{array}{c}\text { Annulus } \\ \text { or } \\ \text { Interior }\end{array} & \text { Date } & \text { WAP } & \text { DP }\end{array}$

Kemarks

\begin{tabular}{|c|c|c|c|c|c|c|}
\hline \multirow[t]{16}{*}{$H$} & \multirow[t]{16}{*}{31} & A- -04 & A & $03 / 11 / 93$ & 7207:04 & $\begin{array}{l}\text { Tank condition was normal. } \\
\text { The conductivity probe was } \\
\text { properly deployed on the } \\
\text { annulus flour. }\end{array}$ \\
\hline & & A-04 & $\mathrm{A}$ & $12 /(02 / 93$ & & $\begin{array}{l}\text { Visual inspection verified } \\
\text { the thermocouple on the } \\
\text { tank wall was properly posi- } \\
\text { tioned. }\end{array}$ \\
\hline & & P.01 & A & $03 / 11 / 93$ & $7207: 05$ & Tank condition was normal. \\
\hline & & P.02 & A & $05 / 04 / 93$ & $7252: 01-25$ & Tank condition was normal. \\
\hline & & P.03 & $\bar{A}$ & $0.3 / 11 / 93$ & $7207: 06$ & Tank condition was normal. \\
\hline & & P.04 & $\bar{A}$ & $03 / 11 / 93$ & $7207: 07$ & Tank condition was normal. \\
\hline & & P.05 & A & $05 / 04 / 93$ & $7253: 01-25$ & Tank condition was normal. \\
\hline & & P.06 & $\mathrm{A}$ & $0.3 / 11 / 93$ & $7207: 08$ & Tank condition was normal. \\
\hline & & P.07 & $\bar{A}$ & $03 / 11 / 93$ & $7207:(04)$ & Tank condition was normal. \\
\hline & & P.08 & $\mathrm{A}$ & $0.5 / 04 / 93$ & $7254: 01-25$ & Tank condition was normal. \\
\hline & & P.09 & $\mathrm{A}$ & $03 / 11 / 93$ & $7207: 10$ & Tank condition was normal. \\
\hline & & P.10 & $\mathrm{A}$ & $03 / 11 / 93$ & $7207: 11$ & Tank condition was normal. \\
\hline & & P.11 & A & $03 / 11 / 93$ & $7207: 12$ & Tank condition was normal. \\
\hline & & P.12 & $\mathrm{A}$ & $05 / 04 / 93$ & $7254: 01-25$ & Tank condition was normal. \\
\hline & & P.13 & $\mathrm{A}$ & $(04 / 21 / 93$ & $7207: 13$ & Tank condition was normal. \\
\hline & & P-14 & A & $0.5 /(04 / 93$ & $7256: 01-25$ & Tank condition was normal. \\
\hline \multirow[t]{13}{*}{$\mathbf{H}$} & \multirow[t]{13}{*}{32} & A.01 & $\bar{A}$ & $0.3 / 11 / 93$ & $7208: 01$ & $\begin{array}{l}\text { Tank condition was normal. } \\
\text { The conductivity prote was } \\
\text { properly deployed on the } \\
\text { annulus floor. }\end{array}$ \\
\hline & & A- 02 & A & $03 / 11 / 93$ & $7208: 02$ & Tank condition was normal. \\
\hline & & A. 02 & $\bar{A}$ & $12 /(12 / 93$ & & $\begin{array}{l}\text { Visual inspection validated } \\
\text { the conductivity prohe was } \\
\text { properly deployed on the } \\
\text { annulus floor. }\end{array}$ \\
\hline & & $\mathrm{A}-\mathbf{0 3}$ & A & $03 / 11 / 93$ & 7208:03 & Tank condition was normal. \\
\hline & & A-04 & A & $03 / 11 / 93$ & 7208:04 & $\begin{array}{l}\text { Tank condition was normal. } \\
\text { The conductivity prote was } \\
\text { properly deployed on the } \\
\text { annulus floor. }\end{array}$ \\
\hline & & A-04 & A & $12 / 02 / 93$ & & $\begin{array}{l}\text { Visual inspection verified } \\
\text { the thermociuple on the } \\
\text { tunk wall was properly posi- } \\
\text { tioned. }\end{array}$ \\
\hline & & P.01 & A & $03 / 11 / 93$ & $7208: 05$ & Tunk condition was normal. \\
\hline & & P.02 & A & $05 / 07 / 93$ & $7271: 01-25$ & Tank condition was normal. \\
\hline & & P.03 & $\mathrm{A}$ & $03 / 11 / 93$ & 7208:06 & Tank condition was normal. \\
\hline & & P-04 & A & $03 / 11 / 93$ & $7208:(07$ & Tink condition was normal \\
\hline & & P.05 & A & $05 / 07 / 93$ & $7272: 01-25$ & Tank condition was normal. \\
\hline & & P.06 & $A$ & $03 / 11 / 93$ & $7208: 08$ & Tank condition was normal. \\
\hline & & P. -07 & A & $0.3 / 11 / 93$ & 72018:(0) & Tank condition was normal. \\
\hline
\end{tabular}


Type of Inspection and Identification Numbers

\begin{tabular}{|c|c|c|c|c|c|c|c|c|}
\hline Area & $\begin{array}{c}\text { Tunk } \\
\text { or } \\
\text { Ancillury }\end{array}$ & $\begin{array}{c}\text { Inspec- } \\
\text { tion } \\
\text { Port }\end{array}$ & $\begin{array}{c}\text { Almulus } \\
\text { or } \\
\text { Interior }\end{array}$ & Date & WAP & DI' & I'SI' & Remarks \\
\hline \multirow[t]{8}{*}{$\mathrm{H}$} & 32 & P.08 & $\mathrm{A}$ & $05 / 07 / 93$ & & $727.3: 01.25$ & & Tank condition was normal. \\
\hline & & P-(4) & $A$ & $0.3 / 11 / 93$ & $7208: 10$ & & & Tank condition was normal. \\
\hline & & P.10 & $\bar{A}$ & $03 / 11 / 93$ & $72018: 11$ & & & $\begin{array}{l}\text { Tank condition was normal. } \\
\text { Stains and marks ohserved } \\
\text { on the unnulus floor were } \\
\text { caused by water inleakage. }\end{array}$ \\
\hline & & P.11 & A & $0.3 / 11 / 93$ & $7208: 12$ & & & Tank condition was normal. \\
\hline & & P.12 & A & $0.5 / 07 / 93$ & & $7274: 01.25$ & & Tank condition was normul. \\
\hline & & P.13 & A & $0.3 / 11 / 93$ & $7208: 13$ & & & Tank condition was normal. \\
\hline & & P.14 & $\mathrm{A}$ & $0,5 / 10 / 93$ & & $7281: 01.25$ & & Tunk condition was normal. \\
\hline & & P.15 & $\bar{A}$ & $0.5 / 10 / 43$ & & $7282: 01.25$ & & Tank conditi,n was normal. \\
\hline F & 33 & $A \cdot 01$ & $A$ & $09 / 10 / 93$ & $74(04: 01$ & & & Tank condition was normal. \\
\hline
\end{tabular}

Stains and marks ohserved on the annulus duct werecaused by water inleakage. The conductivity prote was properly deployed on the annulus floor.

$\begin{array}{llll}\text { A.02 } & \text { A } & 09 / 10 / 93 & 7409: 02\end{array}$

Tank condition was normal. Stains and marks observed on the unnulus duct were caused by water inleakage. The conductivity probe was properly deployed on the unnulus floor.

\begin{tabular}{llll}
\hline A.03 & A & $09 / 10 / 93$ & $7409: 03$ \\
\hline A.04 & A & $09 / 10 / 93$ & $7409: 04$
\end{tabular}

Tank condition was normal.

Tank condition was normal.

An ahsortunt wipe was ohserved utop the annulus duct. The thermocouple was properly positioned on the tank wall.

\begin{tabular}{|c|c|c|c|c|}
\hline P.01 & $\mathrm{A}$ & $09 / 10 / 93$ & 7409:05 & Tank condition was normal. \\
\hline P-02 & A & $(0) / 14 / 43$ & $7434: 01-25$ & Tank condition was normal. \\
\hline P-0.3 & A & $09 / 10 / 93$ & 7409:06 & Tank condition was normal. \\
\hline P-(04 & $A$ & $09 / 10 / 93$ & 7409:07 & Tunk condition was normal. \\
\hline P.0.5 & $A$ & $09 / 14 / 93$ & $7435: 01-25$ & Tunk condition was normal. \\
\hline P.06 & $\bar{A}$ & $09 / 10 / 93$ & 7409:08 & $\begin{array}{l}\text { Tank condition was normal. } \\
\text { Stains and marks ohserved } \\
\text { on the ventilation duct were } \\
\text { caused by water inleakage. }\end{array}$ \\
\hline P-07 & A & $09 / 10 / 93$ & 7409:09 & Tunk condition was normul. \\
\hline P.08 & $\mathrm{A}$ & $09 / 14 / 93$ & $74.36: 01-2.5$ & Tunk condition was normal. \\
\hline P.09 & $\mathrm{A}$ & $09 / 10 / 93$ & $7409: 10$ & Tank condition was normal. \\
\hline P.10 & $A$ & $09 / 10 / 93$ & 7409:11 & Tank condition was normal. \\
\hline P.11 & $\mathrm{A}$ & $09 / 10 / 93$ & $7409: 12$ & Tank condition was normal. \\
\hline P.12 & $\mathrm{A}$ & $09 / 14 / 93$ & $74.37: 01-25$ & Tunk condition was normal. \\
\hline $\bar{P}-13$ & $\bar{A}$ & $09 / 10 / 93$ & $7409: 13$ & Tank condition was normal. \\
\hline
\end{tabular}


Type of Inspection and Identilicution Numbers

\begin{tabular}{|c|c|c|c|c|c|c|c|}
\hline Area & $\begin{array}{c}\text { Tunk } \\
\text { or } \\
\text { Ancillury }\end{array}$ & $\begin{array}{l}\text { Inspec- } \\
\text { tion } \\
\text { Port }\end{array}$ & $\begin{array}{l}\text { Annulus } \\
\text { or } \\
\text { Interior }\end{array}$ & Dufe & WAP & DP' & 's's' \\
\hline \multirow[t]{4}{*}{$F$} & 33 & P.14 & $\Lambda$ & $(0) / 14 / 013$ & & $7438:(1) 1-25$ & \\
\hline & & P.15 & $\Lambda$ & $(09 / 14 / 93$ & & $7430:(01.25$ & \\
\hline & & P.16 & $\Lambda$ & $(09 / 10 / 9) 3$ & $74(0): 14$ & & \\
\hline & & C.01 & 1 & $10 / 15 / 93$ & & & \\
\hline
\end{tabular}

Tank condition was normal Stalins and deposits ohserved oII the secondary vessel wall were caused by water inleakange. Tank condition was normal. Tank condition was normal. ("IV was used li) deler. mine the type jot installed in the ('-1 riser. The inspection determined that the jot conneclor asseinhly was per prist number W239650. The inspection was dexcumented un File Tape "1261.

\begin{tabular}{|c|c|c|c|c|c|c|}
\hline \multirow{16}{*}{\multicolumn{2}{|c|}{34}} & A.01 & $\Lambda$ & $(0) / 10 / 03$ & $741(1: 01$ & $\begin{array}{l}\text { Tank condition was norinal. } \\
\text { The conductivity protwe was } \\
\text { properly deployed on the } \\
\text { annulus floor. }\end{array}$ \\
\hline & & A.02 & A & $0(9 / 10 / 93$ & $7410: 02$ & $\begin{array}{l}\text { Tank condition was normal. } \\
\text { The conductivity protue was } \\
\text { properly deployed on the } \\
\text { annulus floor. }\end{array}$ \\
\hline & & A.03 & $A$ & $(0) / 10 / 1) 3$ & $7410: 03$ & Tank condition was normul. \\
\hline & & A.04 & A & $09 / 1(0 / 1) 3$ & 741()$:(14$ & $\begin{array}{l}\text { Tank condition was normal. } \\
\text { The thernnocouple was prop- } \\
\text { erly pessitioned on the lank } \\
\text { wall. }\end{array}$ \\
\hline & & P.(01 & A & $09 / 10 / 03$ & $7410: 0.5$ & Tank condition was normal. \\
\hline & & P.02 & $A$ & $09 / 1.5 / 93$ & $742.5: 01-25$ & Tank condition was normal. \\
\hline & & P.03 & A & $(09 / 10 / 93$ & $7410: 06$ & Tank condition was normal. \\
\hline & & P.04 & $\mathbf{A}$ & $(09 / 10 / 93$ & $7410: 07$ & Tank condition was normal. \\
\hline & & P.05 & 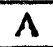 & $(0) / 15 / 93$ & $7426: 01-25$ & Tank condition was normal. \\
\hline & & P.06 & $\mathbf{A}$ & $(0) / 10 / 43$ & $7410: 08$ & Tunk condition was normal. \\
\hline & & P.07 & A & $09 / 10 / 93$ & $7410: 09$ & Tank condition was normal. \\
\hline & & P.08 & $\bar{A}$ & $(9) / 15 / 93$ & $7427:(01-25$ & $\begin{array}{l}\text { Additional stains and marks } \\
\text { ohserved on the tank wall } \\
\text { and ventilation duct were } \\
\text { caused lyy water inleakuge } \\
\text { since inspected on 03-16-89. } \\
\text { No other change was } \\
\text { ohserved in the tank. }\end{array}$ \\
\hline & & P.(5) & $\Lambda$ & $09 / 10 / 93$ & $7410: 10$ & $\begin{array}{l}\text { Tank condition was normal. } \\
\text { Stains and marks observed } \\
\text { on the ventilation duct were } \\
\text { caused by water inleakage. }\end{array}$ \\
\hline & & P.10 & $A$ & $00 / 10 /(9) 3$ & $7410: 11$ & Tank condition was normul. \\
\hline & & P.11 & $\mathrm{A}$ & $09 / 10 / 03$ & $7410: 12$ & Tank condition was morinal. \\
\hline & & P.12 & $A$ & $09 / 1.5 / 93$ & $7428: 01-25$ & Tank condition was normal. \\
\hline
\end{tabular}


Type of lispection aind

Identificullon Numbers

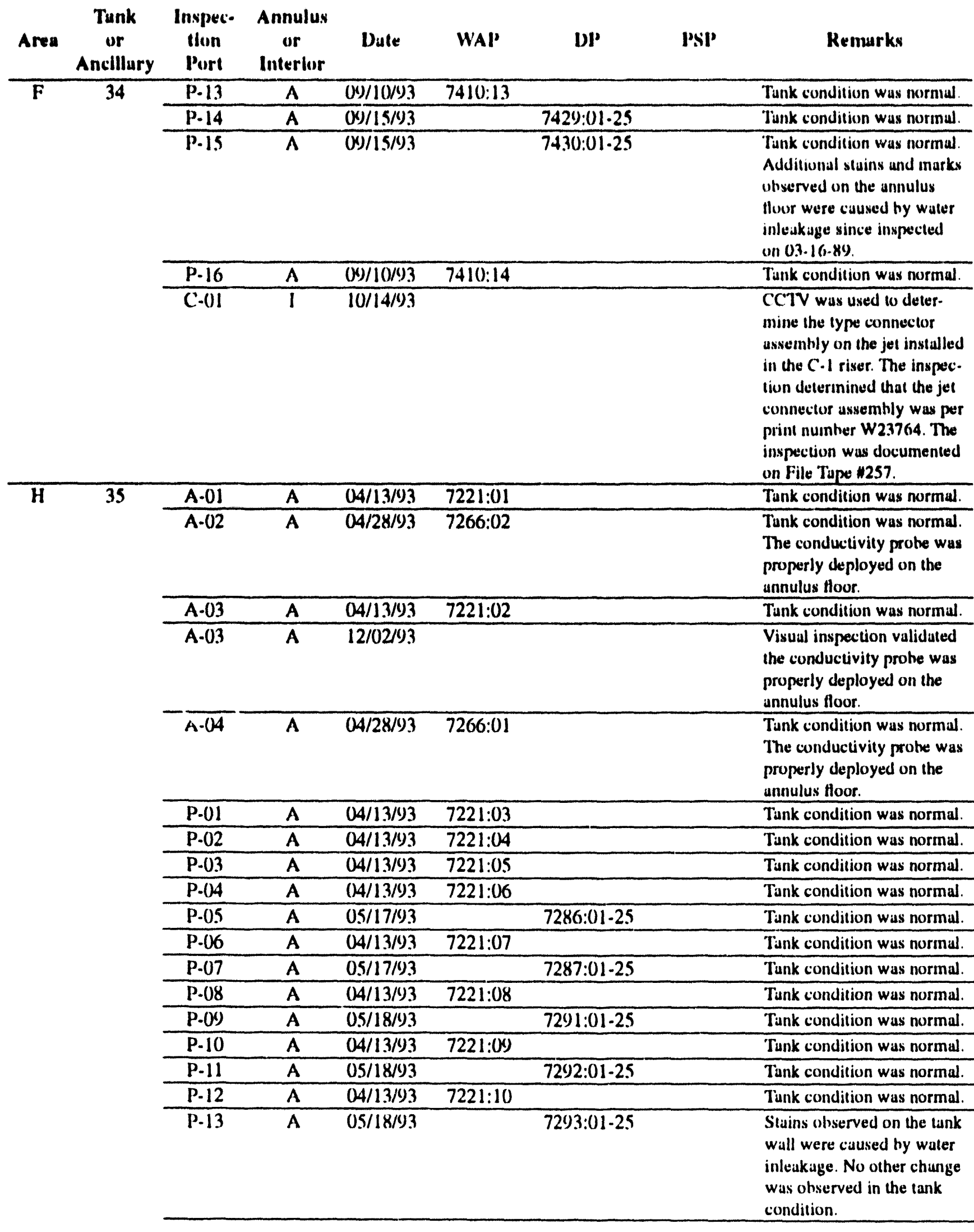


Type of Inspection und

Identiflicullon Numbers

\begin{tabular}{|c|c|c|c|c|c|c|}
\hline Are & $\begin{array}{l}\text { Tunk } \\
\text { or }\end{array}$ & $\begin{array}{l}\text { Inspec- } \\
\text { liun }\end{array}$ & $\begin{array}{c}\text { Annulus } \\
\text { or }\end{array}$ & Dute & IVAP & IJI \\
\hline
\end{tabular}
Ancillary Port Interior

\begin{tabular}{|c|c|c|c|c|c|c|}
\hline H & 35 & P.14 & $\Lambda$ & $(04 / 1,3 / 9) 3$ & $7221: 11$ & Tank condlion was normal. \\
\hline $\mathrm{H}$ & 36 & A.01 & $\bar{A}$ & $(04 / 13 / 93$ & $7240: 01$ & Tank condilion was normal. \\
\hline & & $\overline{A \cdot 02}$ & $\bar{A}$ & $04 / 13 / 3 / 3$ & $7240:(12$ & $\begin{array}{l}\text { Tink condition was normal. } \\
\text { The conductivity protes was } \\
\text { properly deployed on the } \\
\text { alnulus lloor. }\end{array}$ \\
\hline
\end{tabular}

$\begin{array}{lllll}\text { A.03 } & \text { A } & 04 / 13 / 93 & 7240: 03 & \text { Tunk condition was normul }\end{array}$
The conductivity prothe was properly depluyed on the unnulux floor.

\begin{tabular}{lllll}
\hline A.04 & A & $04 / 13 / 93$ & $724(1): 04$ & Tunk condition was normal. \\
& & $\begin{array}{l}\text { The conductivity prote was } \\
\text { properly deployed on the } \\
\text { unnulus flour. }\end{array}$ \\
\hline
\end{tabular}

\begin{tabular}{|c|c|c|c|c|}
\hline P.01 & A & $04 / 13 / 93$ & $7240: 05$ & Tank condition was normal. \\
\hline P.02 & A & $04 / 13 / 03$ & $7240: 06$ & Tank condition was normal. \\
\hline P.03 & $\mathbf{A}$ & $04 / 13 / 03$ & 7240:07 & Tank conditionl was normal. \\
\hline P. 04 & $\mathbf{A}$ & $04 / 13 / 93$ & 7240:08 & Tank condition was normal. \\
\hline P.05 & $\bar{A}$ & $05 / 10 / 93$ & $727.5: 01.25$ & Tank condition was normal. \\
\hline P.06 & $\mathbf{A}$ & $04 / 13 / 93$ & $724(0:(0)$ & Tank condition was normal. \\
\hline P.07 & $\bar{A}$ & $0.5 / 10 / 93$ & $7277: 01.25$ & Tank condition was nornial. \\
\hline P-08 & $\mathbf{A}$ & $04 / 13 / 93$ & $7240: 10$ & Tank condition was norr al. \\
\hline P.(N) & $A$ & $0.5 / 10 / 03$ & $7278:(01.25$ & Tank condition was $n$ rmul. \\
\hline P.10 & $\Lambda$ & $(14 / 13 / 1) 3$ & $7240: 11$ & Tank condition was normal. \\
\hline P.11 & A & $05 / 20 / 93$ & $7279: 01-25$ & Tank condition was normul. \\
\hline P.12 & A & $04 / 13 / 93$ & $7240: 12$ & Tank condition was normal. \\
\hline P.13 & A & $05 / 10 / 93$ & $7280: 01.25$ & Tink condition was normal. \\
\hline P.14 & $\mathrm{A}$ & $04 / 13 / 93$ & $7240: 13$ & Tank condition was normal. \\
\hline G & I & $0.5 / 14 / 93$ & & $\begin{array}{l}\text { CCTV inspection was made } \\
\text { lo document conditions after } \\
\text { an unexplained level } \\
\text { increased occurred. No } \\
\text { unusual conditions were } \\
\text { uhserved. The inspection } \\
\text { was documented on File } \\
\text { Tape } \$ 246 \text {. }\end{array}$ \\
\hline G & I & $0.5 / 2.5 / 93$ & & $\begin{array}{l}\text { CCTV inspection was made } \\
\text { lo document conditions fol- } \\
\text { lowing a } 5 \text { inch transfer of } \\
\text { waste from the tank. No } \\
\text { unusual condition was } \\
\text { olserved. The inspection } \\
\text { was documented on File } \\
\text { lape } \$ 248 \text {. }\end{array}$ \\
\hline
\end{tabular}


Type of Inspection und Identilication Numbers

Tunk Inspec- Antiulus

\begin{tabular}{|c|c|c|c|c|c|c|c|c|}
\hline Area & $\begin{array}{c}\text { or } \\
\text { Ancillury }\end{array}$ & $\begin{array}{l}\text { llon } \\
\text { Purt }\end{array}$ & $\begin{array}{c}\text { or } \\
\text { Interior }\end{array}$ & Dute & WAI' & UP' & PSI' & Remurks \\
\hline
\end{tabular}

H $36 \quad$ II $05 / 14 / 933$ C(TV inspection was made
II) document conditions after an unexplained level increase oceurred No unusual condition was observed. The inspection was documented of File Tupe 24.5

II $10.5 / 2.5 / 93$ CCTV insprection was made
to decument conditions following a 5 inch transfer of waste froin the tank. No unusual condition was observed. The inspection was documented on File Tupe 248.

$\begin{array}{lll}H & \text { I } & 0(0) / 20 / 93\end{array}$

CCTV inspection was made 10 investigate discrepancy in wisle level measurements. Cause of the discrepancy was nol observed. The inspection was documented on File Tape "2.55.

\begin{tabular}{|c|c|c|c|c|c|}
\hline \multirow[t]{15}{*}{37} & A.01 & A & $04 / 13 / 93$ & $7243:() 1$ & Tank condition was normal. \\
\hline & A.02 & $\bar{A}$ & $04 / 13 / 93$ & $7243:(12$ & $\begin{array}{l}\text { Tank condition was normal. } \\
\text { The conductivity prothe was } \\
\text { properly deployed on the } \\
\text { anmulus floor. }\end{array}$ \\
\hline & A.03 & A & $04 / 13 / 93$ & $7243: 03$ & $\begin{array}{l}\text { Tank condition was normal. } \\
\text { The conductivity probe was } \\
\text { properly deployed on the } \\
\text { annulus floor. }\end{array}$ \\
\hline & A.04 & A & $04 / 1.3 / 03$ & $7243: 04$ & $\begin{array}{l}\text { Tunk condition was normal. } \\
\text { The conductivity probe was } \\
\text { properly deployed on the } \\
\text { annulus floor. }\end{array}$ \\
\hline & P.01 & A & $04 / 1.3 / 93$ & $7243: 05$ & Tunk condition was normal. \\
\hline & P.02 & $\mathbf{A}$ & $04 / 13 / 93$ & $7243: 06$ & Tank condition was normal. \\
\hline & P.0.3 & A & $04 / 13 / 93$ & $724.3: 07$ & Tunk condition was normal. \\
\hline & P.04 & A & $04 / 13 / 93$ & $724.3: 08$ & Tunk condition was normal. \\
\hline & P.0.5 & $\mathbf{A}$ & $05 / 10 / 93$ & $7283: 01-25$ & Tunk condition was normal. \\
\hline & P.06 & A & $04 / 13 / 93$ & $7243:(4)$ & Tunk condition was normal. \\
\hline & P.07 & A & $05 / 10 / 03$ & $7284: 01-25$ & Tank condition was normal. \\
\hline & P.08 & $A$ & $04 / 13 / 93$ & $7243: 10$ & Tank condition was normal. \\
\hline & P.(N) & $\bar{A}$ & $05 / 10 / 93$ & $7285: 01-25$ & $\begin{array}{l}\text { Tunk condition was normal. } \\
\text { A piecte of tygon tuhing was } \\
\text { uhserved on the annulus } \\
\text { floor. }\end{array}$ \\
\hline & P.10 & $A$ & $04 / 13 / 93$ & $7243: 11$ & Tunk condition was normal. \\
\hline & P.11 & $A$ & $05 / 18 / 93$ & $7294: 01-2.5$ & Tank condition was normal. \\
\hline
\end{tabular}


Type of linspection and

Identificution Numbers

\begin{tabular}{|c|c|c|c|c|c|c|c|}
\hline Area & $\begin{array}{c}\text { Tunk } \\
\text { or } \\
\text { Ancillary }\end{array}$ & $\begin{array}{l}\text { Inspec- } \\
\text { tion } \\
\text { Port }\end{array}$ & $\begin{array}{l}\text { Anmulus } \\
\text { or } \\
\text { Interior }\end{array}$ & Dute & WAP & PSP & Kemarks \\
\hline \multirow[t]{3}{*}{$\mathrm{H}$} & 37 & P.12 & $\Lambda$ & $(14 / 1.3 / 93$ & $7243: 12$ & & Tank condition was normal. \\
\hline & & P. 13 & $A$ & $0.5 / 18 / 03$ & & $7295:(01-25$ & Tank condition was normal \\
\hline & & P-14 & $A$ & $(14 / 13 / 93$ & $7243: 13$ & & Tank condition was normal. \\
\hline \multirow[t]{18}{*}{$\bar{H}$} & 38 & A. $(01$ & $\Lambda$ & $04 / 1.5 / 03$ & $7228:(1)$ & & Tank condition was normal. \\
\hline & & A.02 & $\Lambda$ & $04 / 15 / 93$ & $7228:(12$ & & $\begin{array}{l}\text { Tank condition was normal. } \\
\text { 'The conductivity probe was } \\
\text { pronerly deployed on the } \\
\text { aumulus floor. }\end{array}$ \\
\hline & & A-03 & $\Lambda$ & $(14 / 1.5 / 93$ & $7228:(1) .3$ & & $\begin{array}{l}\text { Stains and marks ohserved } \\
\text { on the anmulus tloor were } \\
\text { caused hy water inleakage. } \\
\text { The conductivity prote was } \\
\text { properly deployed on the } \\
\text { annulus floor. }\end{array}$ \\
\hline & & A. $-(24$ & $A$ & $04 / 15 / 93$ & $7228:(4)$ & & $\begin{array}{l}\text { Tank condition was normal. } \\
\text { The conductivity probe was } \\
\text { properly deployed on the } \\
\text { unnulus floor. }\end{array}$ \\
\hline & & P.01 & $\mathbf{A}$ & $(24 / 1.5 / 93$ & $7228: 05$ & & Tunk condition was normal. \\
\hline & & P.02 & $A$ & $04 / 1.5 / 93$ & $7228:(16$ & & Tunk condition was normal. \\
\hline & & P.03 & $\mathrm{A}$ & $04 / 1.5 / 93$ & $7228: 07$ & & Tank condition was normal. \\
\hline & & P. 04 & $A$ & $(14 / 15 / 93$ & $7228: 08$ & & Tank condition was normal. \\
\hline & & P.05 & $\Lambda$ & $04 / 1.5 / 93$ & 7228:04 & & Tank condition was normal. \\
\hline & & P. 06 & A & $04 / 15 / 93$ & $7228: 10$ & & Tuluk condition was normal. \\
\hline & & P.07 & $A$ & $04 / 1.5 / 93$ & $7228: 11$ & & Tunk condition was normal. \\
\hline & & P.08 & A & $04 / 15 / 93$ & $7228: 12$ & & $\begin{array}{l}\text { Tank condition was normal. } \\
\text { Stains and marks ohserved } \\
\text { on the annulus floor were } \\
\text { caused by water inleakuge. }\end{array}$ \\
\hline & & P-(O) & $\mathrm{A}$ & $04 / 1.5 / 93$ & $7228: 13$ & & Tank condition was normul. \\
\hline & & P.10 & $A$ & $(02 / 24 / \varphi 3$ & & $7180: 01-25$ & Tank condition was normal. \\
\hline & & P-11 & $\mathbf{A}$ & $02 / 24 / 93$ & & $7190: 01-25$ & Tank condition was normal. \\
\hline & & P.12 & $\Lambda$ & $02 / 24 / 93$ & & 7193:01-25 & Tank condition was normal. \\
\hline & & P-13 & $\Lambda$ & $02 / 24 / 93$ & & $7194: 01-25$ & Tank condition was normul. \\
\hline & & P.14 & $\bar{A}$ & $0.3 /(01 / 93$ & & $7105: 01-25$ & Tank condition was normal. \\
\hline \multirow[t]{4}{*}{$\mathrm{H}$} & 39 & A.01 & $\Lambda$ & $02 / 03 / 93$ & $7181: 01$ & & Tank condition was normal. \\
\hline & & A.(12 & $\bar{A}$ & $(12 / 03 / 93$ & $7181: 02$ & & $\begin{array}{l}\text { Tank condition was normal. } \\
\text { The conductivity probe was } \\
\text { properly deployed on the } \\
\text { annulus floor. }\end{array}$ \\
\hline & & A.03 & A & $02 / 03 / 93$ & $7181: 03$ & & $\begin{array}{l}\text { Tink condition was normal. } \\
\text { The conductivity prote was } \\
\text { properly deployed on the } \\
\text { annulus floor. }\end{array}$ \\
\hline & & A. 04 & $A$ & $02 / 03 / 93$ & $7181: 04$ & & $\begin{array}{l}\text { Tank condition was norinal. } \\
\text { The conductivity probe was } \\
\text { properly deployed on the } \\
\text { amnulus floor. }\end{array}$ \\
\hline
\end{tabular}


Type of Inspection and Identification Numbers

\begin{tabular}{|c|c|c|c|c|c|c|c|}
\hline Area & $\begin{array}{l}\text { Tunk } \\
\text { or } \\
\text { Ancillary }\end{array}$ & $\begin{array}{l}\text { Inspec. } \\
\text { tion } \\
\text { Port }\end{array}$ & $\begin{array}{l}\text { Annulus } \\
\text { or } \\
\text { Interior }\end{array}$ & Date & WAP' & PSP & Remurks \\
\hline \multirow[t]{15}{*}{$\mathrm{H}$} & 39 & P.01 & $\Lambda$ & $02 / 0.3 / 93$ & $7181: 05$ & & Tunk condition was normal. \\
\hline & & P.02 & $\bar{A}$ & $02 /(0.3 / 9) 3$ & $7181: 06$ & & Tank condition was normal. \\
\hline & & P.03 & $\bar{A}$ & $(02 / 0.3 / 93$ & $7181: 07$ & & Tank condition was normal. \\
\hline & & P. 04 & $\bar{A}$ & $02 / 03 / 93$ & $7181: 08$ & & $\begin{array}{l}\text { Stuins and inarks observed } \\
\text { on the annulus floor were } \\
\text { caused by water inleakage. } \\
\text { No other change was } \\
\text { ohserved in the tank condi- } \\
\text { tion. }\end{array}$ \\
\hline & & P-0.5 & A & $02 / 03 / 93$ & $7181: 09$ & & $\begin{array}{l}\text { Tunk condition was normal. } \\
\text { Additional inspection } \\
\text { required to identify the } \\
\text { object on the annulus floor. }\end{array}$ \\
\hline & & P.0.5 & $A$ & $02 / 24 / 93$ & & & $\begin{array}{l}\text { Visual inspection was made } \\
\text { to identify an object } \\
\text { ohserved on the annulus } \\
\text { Hoor in a photograph made } \\
\text { on } 02-03.93 \text {. The investiga- } \\
\text { tion revealed pieces of thin } \\
\text { sheets of plastic on the annu- } \\
\text { lus floor. }\end{array}$ \\
\hline & & P.06 & A & $02 / 0.3 / 93$ & $7181: 10$ & & Tank condition was normal. \\
\hline & & P-(07 & $A$ & $02 / 0.3 / 93$ & $7181: 11$ & & Tunk condition was nurmal. \\
\hline & & P.08 & $A$ & $02 / 03 / 93$ & $7181: 12$ & & Tunk condition was normal. \\
\hline & & $P-(x)$ & A & $02 / 03 / 93$ & $7181: 13$ & & Tunk condition was normal. \\
\hline & & P-10 & $\mathrm{A}$ & $02 / 03 / 93$ & $7181: 14$ & & Tunk condition was normal. \\
\hline & & $P-11$ & $A$ & $03 / 01 / 93$ & & 7196:01-25 & Tank condition was normal. \\
\hline & & $\mathrm{P}-12$ & $\bar{A}$ & $03 / 01 / 93$ & & $7197: 01-25$ & Tunk condition was normal. \\
\hline & & P-13 & A & $03 / 01 / 93$ & & 7198:01-25 & Tunk condition was normal. \\
\hline & & P-14 & $\mathrm{A}$ & $04 / 21 / 93$ & & $7190: 01-25$ & Tunk condition was normal. \\
\hline \multirow[t]{9}{*}{$\mathbf{H}$} & 40 & A-01 & $\mathrm{A}$ & $02 / 0.3 / 93$ & $7180: 01$ & & Tunk condition was normal. \\
\hline & & A.01 & $A$ & $09 / 21 / 93$ & & 7447:01-22 & Tunk condition was normal. \\
\hline & & A-02 & A & $02 / 03 / 93$ & $7180: 02$ & & Tank condition was normal. \\
\hline & & $\mathrm{A}-02$ & $\bar{A}$ & $09 / 21 / 93$ & & $7441: 01-23$ & $\begin{array}{l}\text { Tank condition was normal. } \\
\text { The conductivity prote was } \\
\text { properly deployed on the } \\
\text { annulus floor. }\end{array}$ \\
\hline & & A-03 & $A$ & $02 / 03 / 93$ & $7180: 03$ & & Tunk condition was normal. \\
\hline & & $A \cdot 03$ & A & $09 / 21 / 93$ & & $7448: 01-25$ & $\begin{array}{l}\text { Tank condition was normal. } \\
\text { The conductivity prote was } \\
\text { properly deployed on the } \\
\text { unnulus floor. }\end{array}$ \\
\hline & & A- -14 & A & $09 / 21 / \circlearrowleft 3$ & & 7449:01.24 & $\begin{array}{l}\text { Tunk condition was normal. } \\
\text { The conductivity prohe was } \\
\text { properly deployed on the } \\
\text { annulus floor. }\end{array}$ \\
\hline & & P.01 & A & $09 / 22 / 93$ & 7450:01 & & Tank condition was normal. \\
\hline & & P-02 & $\mathrm{A}$ & $04 / 21 / 93$ & & $7233: 01-25$ & Tank condition was normal. \\
\hline
\end{tabular}


Type of Inspection and

Identification Numbers

\begin{tabular}{|c|c|c|c|c|c|c|c|}
\hline Area & $\begin{array}{c}\text { Tank } \\
\text { or } \\
\text { Ancillary }\end{array}$ & $\begin{array}{c}\text { Inspec- } \\
\text { tion } \\
\text { Port }\end{array}$ & $\begin{array}{c}\text { Annulus } \\
\text { or } \\
\text { Interior }\end{array}$ & Date & WAP & PSP & Remurks \\
\hline \multirow[t]{12}{*}{$\mathbf{H}$} & 40 & P-03 & $\mathrm{A}$ & $02 / 03 / 93$ & $7180: 04$ & & Tank condition was normal. \\
\hline & & P.04 & $\bar{A}$ & $02 / 03 / 93$ & $7180: 0.5$ & & Tank condition was normal. \\
\hline & & P-0.5 & $\mathbf{A}$ & $02 / 03 / 93$ & $7180: 06$ & & Tunk condition was normal. \\
\hline & & P-06 & $\bar{A}$ & $02 / 03 / 93$ & 7180:07 & & Tank condition was normal. \\
\hline & & P-07 & $\bar{A}$ & $02 / 03 / 93$ & $7180: 08$ & & Tank condition was normal. \\
\hline & & P-08 & $\mathbf{A}$ & $02 / 03 / 93$ & $7180:(09$ & & Tank condition was normal. \\
\hline & & P-09 & $\bar{A}$ & $02 / 03 / 93$ & $7180: 10$ & & Tank condition was normal. \\
\hline & & $\mathrm{P}-10$ & $\mathbf{A}$ & $02 / 03 / 93$ & $7180: 11$ & & Tunk condition was normal. \\
\hline & & P-11 & $\bar{A}$ & $02 / 03 / 93$ & $7180: 12$ & & $\begin{array}{l}\text { Stiains and marks observed } \\
\text { on the annulus wall were } \\
\text { caused hy water inleakage. } \\
\text { No other change was } \\
\text { observed in the tank. }\end{array}$ \\
\hline & & P-12 & A & $04 / 21 / 93$ & & $7234: 01-25$ & Tank condition was normal. \\
\hline & & P-13 & $\bar{A}$ & $09 / 29 / 93$ & & $7235: 01-23$ & Tank condition was normal. \\
\hline & & P-14 & $\bar{A}$ & $02 / 03 / 93$ & $7180: 13$ & & Tunk condition was normal. \\
\hline \multirow[t]{18}{*}{ H } & 41 & A-01 & $\bar{A}$ & $05 / 03 / 93$ & $7269: 01$ & & Tank condition was normal. \\
\hline & & A-02 & $\bar{A}$ & $05 / 03 / 93$ & $7269: 02$ & & $\begin{array}{l}\text { Tank condition was normal. } \\
\text { The conductivity probe was } \\
\text { properly deployed on the } \\
\text { annulus floor. }\end{array}$ \\
\hline & & A-03 & $\bar{A}$ & $05 / 03 / 93$ & $7269: 03$ & & $\begin{array}{l}\text { Tank condition was normal. } \\
\text { The conductivity probe was } \\
\text { properly deployed on the } \\
\text { annulus floor. }\end{array}$ \\
\hline & & A-04 & $\bar{A}$ & $05 / 03 / 93$ & $7269: 04$ & & $\begin{array}{l}\text { Tank condition was normal. } \\
\text { The conductivity probe was } \\
\text { properly deployed on the } \\
\text { annulus foor. }\end{array}$ \\
\hline & & P-01 & $\mathrm{A}$ & $05 / 03 / 93$ & $7269: 05$ & & Tank condition was normal. \\
\hline & & $\mathrm{P}-02$ & A & $05 / 03 / 93$ & $7269: 06$ & & Tank condition was normal. \\
\hline & & P-03 & $\mathbf{A}$ & $05 / 03 / 93$ & $7269: 07$ & & Tank condition was normal. \\
\hline & & P-04 & $\mathrm{A}$ & $05 /(03 / 93$ & 7269:08 & & Tank condition was normal. \\
\hline & & P-05 & $\mathrm{A}$ & $05 / 03 / 93$ & $7269:(09)$ & & Tank condition was normal. \\
\hline & & P-06 & $\mathrm{A}$ & $05 / 03 / 93$ & $7269: 10$ & & Tank condition was normal. \\
\hline & & P-07 & $\bar{A}$ & $09 / 22 / 93$ & $7451: 01$ & & $\begin{array}{l}\text { Additional stains and marks } \\
\text { ohserved on the annulus } \\
\text { floor were caused by water } \\
\text { inleakage. No other change } \\
\text { was observed in the tank. }\end{array}$ \\
\hline & & P-08 & $\mathrm{A}$ & $05 / 03 / 93$ & $7269: 11$ & & Tank condition was normal \\
\hline & & P-09 & A & $05 / 03 / 93$ & $7269: 12$ & & Tank condition was normal. \\
\hline & & P-10 & $A$ & $04 / 12 / 93$ & & $7222: 01-25$ & Tank condition was normal. \\
\hline & & P-11 & $\mathrm{A}$ & $04 / 12 / 93$ & & $7223: 01-25$ & Tank condition was normal. \\
\hline & & P-12 & $\mathrm{A}$ & $04 / 12 / 93$ & & $7224: 01-25$ & Tank condition was normal. \\
\hline & & $\mathrm{P}-13$ & $\mathrm{~A}$ & $04 / 21 / 93$ & & $7236: 01-25$ & Tank condition was normal \\
\hline & & P-14 & $\mathrm{A}$ & $04 / 21 / 93$ & & $7237: 01.25$ & Tank condition was normal. \\
\hline
\end{tabular}


Type of Inspection and

Identification Numbers

\begin{tabular}{|c|c|c|c|c|c|c|}
\hline Area & $\begin{array}{c}\text { Tank } \\
\text { or } \\
\text { Ancillary }\end{array}$ & $\begin{array}{l}\text { Inspec- } \\
\text { tion } \\
\text { Port }\end{array}$ & $\begin{array}{c}\text { Annulus } \\
\text { or } \\
\text { Interior }\end{array}$ & Date & WAP & DP \\
\hline $\mathbf{H}$ & 41 & B-03 & I & $34 / 24 / 93$ & & \\
\hline
\end{tabular}

PSP Remarks

CCTV inspection during trunsfer revealed no salt present ahove liquid surface after 5 inches of supernate was transferred from the tank. The inspection was documented of File Tape $\# 244$.

E-01 1 05/18/93 CCTV inspection was made
to document conditions after an unexplained level increase occurred. No unusual condition was ohserved.

\begin{tabular}{|c|c|c|c|c|c|}
\hline \multirow[t]{20}{*}{42} & A-01 & A & $09 / 21 / 93$ & $7442:(01-23$ & Tunk condition was normal. \\
\hline & A.02 & $\mathrm{A}$ & $09 / 13 / 93$ & 7432:01 & Tank condition was normal. \\
\hline & A.02 & $\bar{A}$ & $12 / 17 / 93$ & $7479: 01-22$ & $\begin{array}{l}\text { Tank condition was normal. } \\
\text { The conductivity probe was } \\
\text { properly deployed on the } \\
\text { annulus floor. }\end{array}$ \\
\hline & A.03 & A & $09 / 13 / 93$ & $7432: 02$ & $\begin{array}{l}\text { Tunk condition was normal. } \\
\text { The conductivity probe was } \\
\text { properly deployed on the } \\
\text { anusulus floor. }\end{array}$ \\
\hline & A-03 & A & $09 / 21 / 93$ & $7443: 01-24$ & Tank condition was normal. \\
\hline & $A-04$ & $\bar{A}$ & $09 / 13 / 93$ & $7432: 03$ & Tunk condition was normal. \\
\hline & $\overline{A-04}$ & $\bar{A}$ & $09 / 21 / 93$ & $7444: 01-23$ & $\begin{array}{l}\text { Tunk condition was normal. } \\
\text { The conductivity probe was } \\
\text { properly deployed on the } \\
\text { annulus floor. }\end{array}$ \\
\hline & P-01 & $\mathbf{A}$ & $09 / 13 / 93$ & 7432:04 & Tank condition was normal. \\
\hline & P-02 & $\mathbf{A}$ & $09 / 13 / 93$ & $7432: 05$ & Tank condition was normal. \\
\hline & P.03 & $\bar{A}$ & $09 / 13 / 93$ & $7432: 06$ & Tunk condition was normal. \\
\hline & P.04 & A & $09 / 13 / 93$ & $7432: 07$ & Tank condition was normal. \\
\hline & P.05 & A & $09 / 13 / 93$ & $74.32: 08$ & Tank condition was normal. \\
\hline & P.06 & $\mathbf{A}$ & $09 / 13 / 93$ & 7432:04) & Tink condition was normal. \\
\hline & P.07 & A & $09 / 13 / 93$ & $74: 32: 10$ & Tank condition was normal. \\
\hline & P.08 & A & $09 / 13 / 93$ & 7432:11 & Tank condition was normal. \\
\hline & P. 09 & A & $09 / 13 / 93$ & $7432: 12$ & Tunk cundition was normal. \\
\hline & P.10 & $\mathrm{A}$ & $09 / 13 / 93$ & $74.32: 13$ & Tank condition was normal. \\
\hline & P.11 & $A$ & $09 / 13 / 93$ & $7432: 14$ & Tank condition was normal. \\
\hline & P-12 & $A$ & $09 / 29 / 93$ & $7458: 01-24$ & Tank condition was normal. \\
\hline & P-13 & $\mathrm{A}$ & $09 / 22 / 93$ & $7445: 01-25$ & Tank condition was normal. \\
\hline
\end{tabular}


Type of Inspection and Identification Numbers

\begin{tabular}{|c|c|c|c|c|c|c|c|}
\hline Area & $\begin{array}{c}\text { Tank } \\
\text { or } \\
\text { Ancillary }\end{array}$ & $\begin{array}{c}\text { Inspec:- } \\
\text { tion } \\
\text { Port }\end{array}$ & $\begin{array}{l}\text { Annulus } \\
\text { or } \\
\text { Interior }\end{array}$ & Date & WAP & PSP & Remarks \\
\hline $\mathrm{H}$ & 42 & P-14 & $A$ & $09 / 22 / 93$ & & $7446: 01-25$ & $\begin{array}{l}\text { Stains and deposits ohserved } \\
\text { on the ventilation duct were } \\
\text { caused by water inleakage. } \\
\text { No other change was } \\
\text { observed in the tank. }\end{array}$ \\
\hline \multirow[t]{17}{*}{$\mathbf{H}$} & 43 & $\mathrm{~A}-01$ & A & $05 / 06 / 93$ & $7276: 01$ & & Tank condition was normal. \\
\hline & & A-02 & $\bar{A}$ & $05 / 06 / 93$ & $7276: 02$ & & $\begin{array}{l}\text { Tank condition was normal. } \\
\text { The conductivity probe was } \\
\text { properly deployed on the } \\
\text { annulus floor. }\end{array}$ \\
\hline & & A-03 & A & $05 / 06 / 93$ & $7276: 03$ & & $\begin{array}{l}\text { Tank condition was normal. } \\
\text { The conductivity prohe was } \\
\text { properly deployed on the } \\
\text { annulus floor. }\end{array}$ \\
\hline & & A-04 & $\bar{A}$ & $05 / 06 / 93$ & $7276: 04$ & & $\begin{array}{l}\text { Tank condition was normal. } \\
\text { The conductivity prohe was } \\
\text { properly deployed on the } \\
\text { annulus floor. }\end{array}$ \\
\hline & & P-01 & A & $05 / 06 / 93$ & 7276:05 & & Tank condition was normal. \\
\hline & & P-02 & $\mathrm{A}$ & $05 / 06 / 93$ & $7276: 06$ & & Tank condition was normal. \\
\hline & & P.03 & $\bar{A}$ & $11 / 30 / 93$ & $7478: 01$ & & $\begin{array}{l}\text { Tank condition was normal. } \\
\text { Stains on the annulus floor } \\
\text { were caused by water } \\
\text { inleakage. }\end{array}$ \\
\hline & & P.04 & $\mathrm{A}$ & $05 / 06 / 93$ & $7276: 07$ & & Tank condition was normal. \\
\hline & & P-05 & $\mathrm{A}$ & $05 / 06 / 93$ & $7276: 08$ & & Tank condition was normal. \\
\hline & & P-06 & $A$ & $05 / 06 / 93$ & $7276: 09$ & & Tank condition was normal. \\
\hline & & P-07 & A & $0.5 / 06 / 93$ & $7276: 10$ & & Tank condition was normal. \\
\hline & & P-08 & A & $05 / 06 / 93$ & $7276: 11$ & & $\begin{array}{l}\text { Tank condition was normal. } \\
\text { Stuins and marks observed } \\
\text { on the annulus floor and } \\
\text { ventilation duct were } \\
\text { caused by water inleakage. }\end{array}$ \\
\hline & & $P-09$ & A & $05 / 06 / 93$ & $7276: 12$ & & $\begin{array}{l}\text { Tunk condition was normal. } \\
\text { Stuins and marks observed } \\
\text { on the annulus floor and } \\
\text { ventilation duct were } \\
\text { caused by water inleakage. }\end{array}$ \\
\hline & & P-10 & A & $04 / 29 / 93$ & & $7250: 01-25$ & Tunk condition was normal. \\
\hline & & P-11 & $\mathrm{A}$ & $04 / 29 / 93$ & & $7251: 01-25$ & Tank condition was normal. \\
\hline & & P-12 & A & $04 / 12 / 93$ & & $7225: 01-25$ & $\begin{array}{l}\text { Tank condition was normal. } \\
\text { The quantity of gilsulate } \\
\text { ohserved on the annulus } \\
\text { floor had increased since } \\
\text { inspected last year. }\end{array}$ \\
\hline & & P-13 & $A$ & $04 / 12 / 93$ & & $7226: 01-25$ & $\begin{array}{l}\text { Tank condition was normal } \\
\text { The quantity of gilsulate } \\
\text { observed on the annulus } \\
\text { floor had increased since } \\
\text { inspected last year. }\end{array}$ \\
\hline
\end{tabular}


Type of Inspection and

Identification Numbers

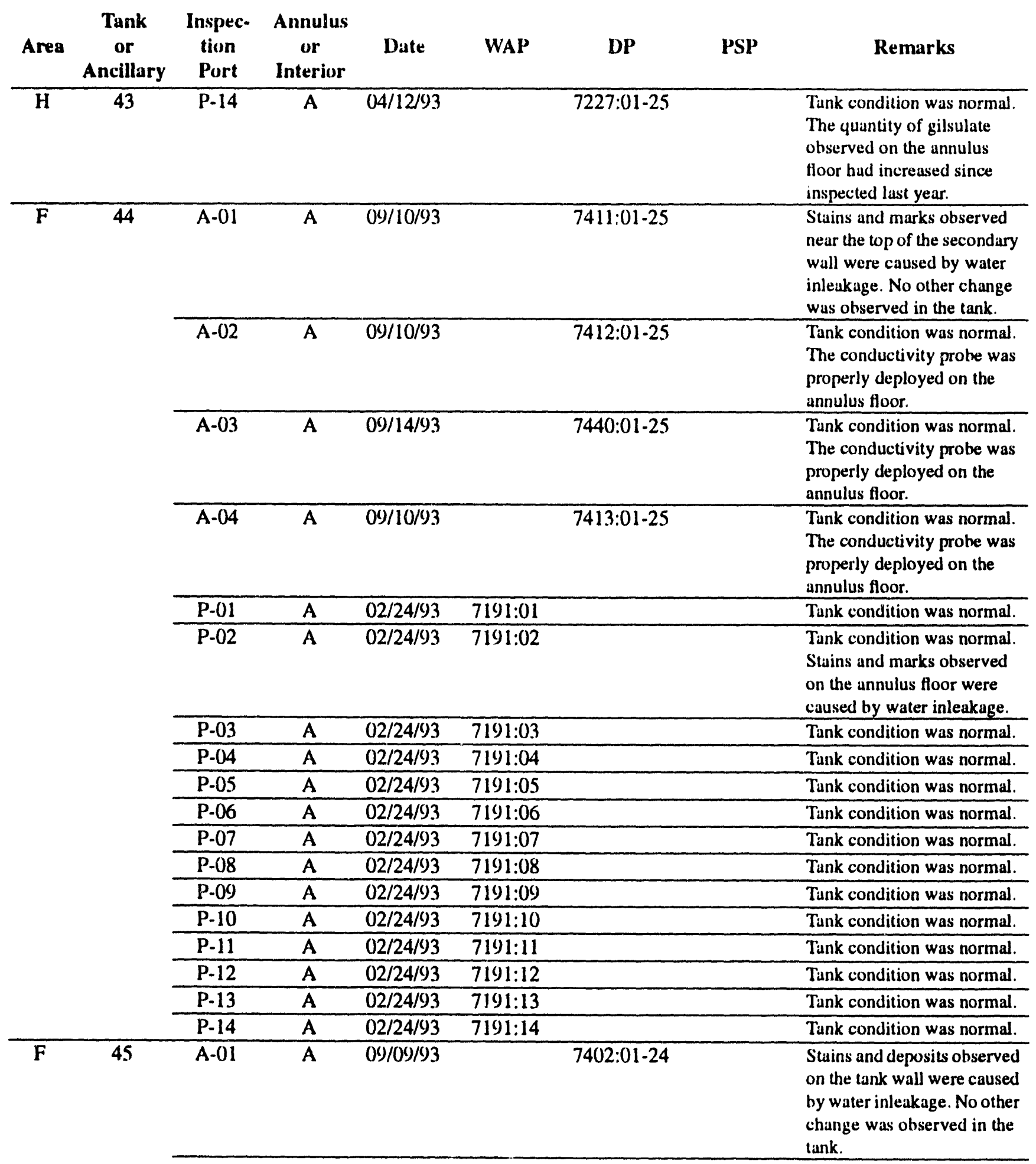


Type of Inspection and

Identification Numbers

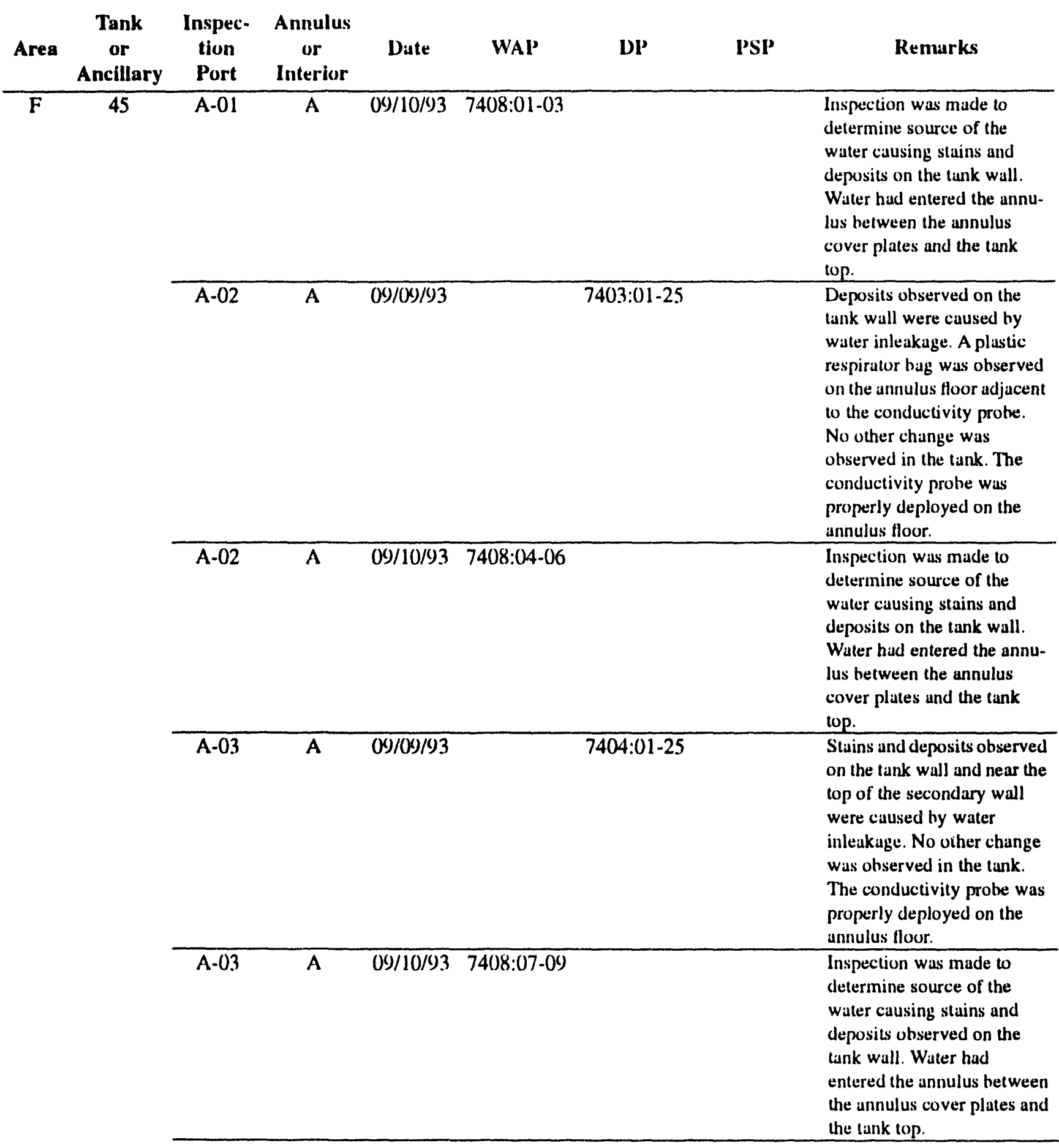


Type of Inspection and Identification Numbers

\begin{tabular}{|c|c|c|c|c|c|c|c|c|}
\hline Area & $\begin{array}{c}\text { Tank } \\
\text { or } \\
\text { Ancillary }\end{array}$ & $\begin{array}{l}\text { Inspec- } \\
\text { tion } \\
\text { Port }\end{array}$ & $\begin{array}{c}\text { Annulus } \\
\text { or } \\
\text { Interior }\end{array}$ & Date & WAP & DP & PSP & Remarks \\
\hline \multirow[t]{16}{*}{$\bar{F}$} & 45 & A. 04 & $\mathrm{~A}$ & $09 /(09 / 93$ & & $7405: 01-26$ & & $\begin{array}{l}\text { Stains and deposits observed } \\
\text { on the secondary wall were } \\
\text { caused by iwater inleakage. } \\
\text { A short piece (ahout } 2-3 \\
\text { feet) of twisted rope was } \\
\text { observed on the annulus } \\
\text { floor. No other chunge was } \\
\text { observed in the tank. The } \\
\text { conductivity probe was } \\
\text { properly deployed on the } \\
\text { annulus floor. }\end{array}$ \\
\hline & & A-(04 & $\bar{A}$ & $09 / 10 / 93$ & $7408: 10-12$ & & & $\begin{array}{l}\text { Inspection was made to } \\
\text { deternine source of the } \\
\text { water causing stains and } \\
\text { deposits on the secondary } \\
\text { wall. Water had entered the } \\
\text { annulus between the annulus } \\
\text { cover plates and the second- } \\
\text { ary wall. }\end{array}$ \\
\hline & & P-01 & A & $02 / 18 / 93$ & 7186:01 & & & Tank condition was normal. \\
\hline & & P.02 & A & $02 / 18 / 93$ & $7186: 02$ & & & Tank condition was normal. \\
\hline & & P-03 & $\bar{A}$ & $02 / 18 / 93$ & $7186: 03$ & & & Tank condition was normal. \\
\hline & & P-04 & $\mathrm{A}$ & $02 / 18 / 93$ & $7186: 04$ & & & Tank condition was normal. \\
\hline & & P-05 & $\bar{A}$ & $02 / 18 / 93$ & $7186: 05$ & & & Tunk condition was normal. \\
\hline & & P-06 & $\mathrm{A}$ & $02 / 18 / 93$ & $7186: 06$ & & & Tank condition was normal. \\
\hline & & P-07 & $\mathrm{A}$ & $02 / 18 / 93$ & $7186: 07$ & & & Tunk condition was normal. \\
\hline & & P-08 & A & $02 / 18 / 93$ & $7186: 08$ & & & Tank condition was normal. \\
\hline & & P.09 & A & $02 / 18 / 93$ & $7186: 09$ & & & $\begin{array}{l}\text { Tunk condition was normal. } \\
\text { Investigation will be made } \\
\text { via the A1, A2, A3, and A4 } \\
\text { risers to determine the } \\
\text { source of stains and marks } \\
\text { observed on the tank and } \\
\text { annulus walls. }\end{array}$ \\
\hline & & P.10 & A & $03 / 08 / 93$ & $7186: 10$ & & & $\begin{array}{l}\text { Tunk condition was normal. } \\
\text { Investigation will be made } \\
\text { via the A1, A2, A3 and A4 } \\
\text { risers to determine the } \\
\text { source of stuins and marks } \\
\text { ohserved on the tank and } \\
\text { annulus walls. }\end{array}$ \\
\hline & & P-11 & $\mathrm{A}$ & $02 / 18 / 93$ & $7186: 11$ & & & Tank cendition was normal. \\
\hline & & P-12 & $\bar{A}$ & $02 / 18 / 93$ & $7186: 12$ & & & Tunk condition was normal. \\
\hline & & $\mathrm{P}-13$ & $\mathrm{~A}$ & $02 / 18 / 93$ & $7186: 13$ & & & Tank condition was normal. \\
\hline & & P.14 & $\mathrm{A}$ & $02 / 18 / 93$ & $7186: 14$ & & & Tunk condition was normal. \\
\hline F & 46 & A.01 & $\mathrm{A}$ & $09 / 13 / 93$ & & $7414: 01-25$ & & Tunk condition was normal. \\
\hline
\end{tabular}


Type of Inspection and

Identification Numbers

\begin{tabular}{|c|c|c|c|c|c|c|c|}
\hline Area & $\begin{array}{c}\text { Tank } \\
\text { or } \\
\text { Ancillary }\end{array}$ & $\begin{array}{l}\text { Inspec- } \\
\text { tion } \\
\text { Port }\end{array}$ & $\begin{array}{c}\text { Annulus } \\
\text { or } \\
\text { Interior }\end{array}$ & Dute & WAP & PSP & Kemarks \\
\hline \multirow[t]{18}{*}{$\bar{F}$} & 46 & A-02 & $A$ & $09 / 13 / 93$ & & $7415: 01-25$ & $\begin{array}{l}\text { Tank condition was normal. } \\
\text { The conductivity prote was } \\
\text { properly deployed on the } \\
\text { annulus tloor. }\end{array}$ \\
\hline & & A-03 & A & $09 / 13 / 93$ & & $7416: 01-25$ & $\begin{array}{l}\text { Tank condition was normal. } \\
\text { Stains and marks ohserved } \\
\text { on the annulus floor were } \\
\text { caused by water inleakage. } \\
\text { The conductivity prothe was } \\
\text { properly deployed on the } \\
\text { annulus floor. }\end{array}$ \\
\hline & & A-04 & A & $09 / 13 / 93$ & & $7417: 01-25$ & $\begin{array}{l}\text { Tank condition was normal. } \\
\text { Alout three feet of tygon } \\
\text { tuhing was observed on the } \\
\text { annulus tloor next to the } \\
\text { conductivity probe. The con- } \\
\text { ductivity prohe was properly } \\
\text { deployed on the annulus } \\
\text { floor. }\end{array}$ \\
\hline & & P.01 & A & $03 / 08 / 93$ & 7184:01 & & Tank condition was normal. \\
\hline & & P.02 & A & $0.3 / 08 / 93$ & $7184: 02$ & & Tank condition was normal. \\
\hline & & P.03 & $\mathrm{A}$ & $03 /(18 / 93$ & $7184: 03$ & & Tank condition was normal. \\
\hline & & P.04 & $\bar{A}$ & $02 / 17 / 93$ & $7184: 04$ & & Tank condition was normal. \\
\hline & & P-05 & A & $02 / 17 / 93$ & $7184: 05$ & & Tank condition was normal. \\
\hline & & P.06 & $\bar{A}$ & $02 / 17 / 93$ & $7184: 06$ & & Tank condition was normal. \\
\hline & & P.07 & A & $02 / 17 / 93$ & $7184: 07$ & & Tank condition was normal. \\
\hline & & P.08 & $\mathrm{A}$ & $02 / 17 / 93$ & $7184: 08$ & & Tank condition was normal. \\
\hline & & P.09 & $\mathrm{A}$ & $02 / 17 / 93$ & $7184: 09$ & & Tank condition was normal. \\
\hline & & P-10 & $\bar{A}$ & $03 / 08 / 93$ & $7184: 10$ & & Tank condition was normul. \\
\hline & & P-11 & $\mathrm{A}$ & $02 / 17 / 93$ & $7184: 11$ & & Tank condition was normal. \\
\hline & & P-12 & $\mathrm{A}$ & $03 / 08 / 93$ & $7184: 12$ & & $\begin{array}{l}\text { Tank condition was normal. } \\
\text { Stuins and marks observed } \\
\text { on the annulus floor were } \\
\text { caused by water inleakage. }\end{array}$ \\
\hline & & P-13 & $\bar{A}$ & $02 / 17 / 93$ & $7184: 13$ & & $\begin{array}{l}\text { Tank condition was normal. } \\
\text { Stains und marks observed } \\
\text { on the annulus floor were } \\
\text { caused by water inleakage. }\end{array}$ \\
\hline & & P.14 & A & $02 / 17 / 93$ & $7184: 14$ & & Tank condition was normal. \\
\hline & & $C-01$ & $I$ & $0.5 / 27 / 93$ & & & $\begin{array}{l}\text { CCTV was used to deter- } \\
\text { mine if a plug was installed } \\
\text { in the discharge line in riser } \\
C-01 \text { (The WF line on draw } \\
\text { ing W-703(59). No plug was } \\
\text { observed. }\end{array}$ \\
\hline $\mathbf{F}$ & 47 & A. 01 & A & $09 / 13 / 93$ & & $7418: 01-25$ & Tank condition was normal. \\
\hline
\end{tabular}


Type of Inspection and

Identification Numbers

\begin{tabular}{|c|c|c|c|c|c|c|c|c|}
\hline Area & $\begin{array}{c}\text { Tunk } \\
\text { or } \\
\text { An }: \text { illary }\end{array}$ & $\begin{array}{l}\text { Inspec- } \\
\text { tion } \\
\text { Port }\end{array}$ & $\begin{array}{c}\text { Annulus } \\
\text { or } \\
\text { lnterior }\end{array}$ & Dute & WAP & DP & I'SP' & Kemarks \\
\hline$F$ & 47 & $\Lambda-02$ & $A$ & $09 / 13 / 93$ & & $7419: 01-24$ & & $\begin{array}{l}\text { Tank condition was norinal. } \\
\text { The conductivity prote was } \\
\text { properly deployed on the } \\
\text { annulus floor. }\end{array}$ \\
\hline
\end{tabular}

$\begin{array}{llll}\text { A. }-03 & \text { A } & 09 / 13 / 93 & 7420: 01-25\end{array}$

unnulus floor.

Tank condition was normal. Changes in the surface stains and marks on the annulus floor indicate additional water inleakage since last inspected on 01-04-89. The conductivity probe was properly deployed on the amnulus floor.

$\begin{array}{llll}\text { A-(04 } & \text { A } & 09 / 13 / 93 & 7421: 01-23\end{array}$

Tank condition was normal. Stains and marks observed on the secondary wall and annulus floor were caused hy water inleakage. A riser plug gasket was otserved atop the ventilation duct. The conductivity probe was properly deployed on the unnulus floor.

\begin{tabular}{|c|c|c|c|c|}
\hline P-01 & A & $02 / 24 / 93$ & $7192: 01$ & $\begin{array}{l}\text { Tunk condition was normal. } \\
\text { Stains and marks observed } \\
\text { on the unnulus floor were } \\
\text { caused by water inleakage. }\end{array}$ \\
\hline P. 02 & A & $02 / 24 / 93$ & $7192: 02$ & $\begin{array}{l}\text { Tunk condition was normal. } \\
\text { Stains and marks observed } \\
\text { on the annulus floor were } \\
\text { caused hy water inleakage. } \\
\text { Ahout three feet of tygon } \\
\text { tuhing was observed on the } \\
\text { annulus floor. }\end{array}$ \\
\hline P.02 & A & $03 / 16^{\prime} 93$ & & $\begin{array}{l}\text { CCTV was used to perform } \\
\text { a leak test of the repaired } \\
\text { seal where the WC1 line } \\
\text { (per drawing W703660) } \\
\text { penetrates the concrete } \\
\text { vault helow grade. During } \\
\text { the hydrotest no water } \\
\text { leaked past the new seal. }\end{array}$ \\
\hline P-03 & A & $03 / 08 / 93$ & $7192: 03$ & $\begin{array}{l}\text { Tunk condition was normal } \\
\text { Stains and marks ohserved } \\
\text { on the annulus floor were } \\
\text { caused by water inleakage. }\end{array}$ \\
\hline P.04 & A & $03 / 08 / 43$ & 7192:04 & $\begin{array}{l}\text { Tank condition was normal. } \\
\text { Stains and marks observed } \\
\text { on the annulus floor were } \\
\text { cuused hy water inleakage. }\end{array}$ \\
\hline
\end{tabular}


Type of Inspection and

Identification Numbers

\begin{tabular}{|c|c|c|c|c|c|c|c|}
\hline Area & $\begin{array}{c}\text { Tank } \\
\text { or } \\
\text { Ancillary }\end{array}$ & $\begin{array}{l}\text { Inspec- } \\
\text { tion } \\
\text { Port }\end{array}$ & $\begin{array}{c}\text { Annulus } \\
\text { or } \\
\text { linterior }\end{array}$ & Date & WAP' & l'sp' & Reinurks \\
\hline \multirow[t]{10}{*}{$F$} & 47 & P.0S & $A$ & $(02 / 24 / 93$ & $71 \cup 2: 05$ & & $\begin{array}{l}\text { Tank condition was normal. } \\
\text { Stains and marks olserved } \\
\text { on the annulus floor were } \\
\text { caused by water inleakage. }\end{array}$ \\
\hline & & P.06 & A & $02 / 24 / 93$ & $7192: 06$ & & $\begin{array}{l}\text { Tank condition was normal. } \\
\text { Stailis and inarks observed } \\
\text { on the annulus floor were } \\
\text { caused by water inleakage. }\end{array}$ \\
\hline & & P-07 & A & $02 / 24 / 93$ & $7192: 07$ & & $\begin{array}{l}\text { Tank condition was normal. } \\
\text { Stains and marks ohserved } \\
\text { on the annulus floor were } \\
\text { caused by water inleakage. }\end{array}$ \\
\hline & & P.08 & $A$ & $03 / 08 / 93$ & $7192: 08$ & & $\begin{array}{l}\text { Tank condition was normal. } \\
\text { Stains and inarks observed } \\
\text { on the anmulus floor were } \\
\text { caused by water inleakage. }\end{array}$ \\
\hline & & P. 09 & A & $03 / 08 / 93$ & $7192: 09$ & & Tank condition was normal. \\
\hline & & P. 10 & A & $03 / 08 / 93$ & $7192: 10$ & & Tunk condition was normul. \\
\hline & & P-11 & A & $0.3 / 08 / 93$ & $7192: 11$ & & Tank condition was normal. \\
\hline & & P.12 & A & $03 / 08 / 93$ & $7192: 12$ & & $\begin{array}{l}\text { Tank condition was normal. } \\
\text { Stains and inarks observed } \\
\text { on the annulus floor were } \\
\text { cuused by water inleakage. }\end{array}$ \\
\hline & & P.13 & A & $03 / 08 / 93$ & $7192: 13$ & & $\begin{array}{l}\text { Tank condition was normal. } \\
\text { Stuins and marks observed } \\
\text { on the annulus floor were } \\
\text { caused hy water inleakage. }\end{array}$ \\
\hline & & P-14 & A & $03 / 08 / 93$ & $7192: 14$ & & $\begin{array}{l}\text { Tank condition was normal. } \\
\text { Stains and onarks ohserved } \\
\text { on the annulus floor were } \\
\text { caused by water inleakuge. }\end{array}$ \\
\hline \multirow[t]{7}{*}{$\mathbf{H}$} & 48 & A.01 & A & $06 / 03 / 93$ & & $7269: 01-2.5$ & Tank condition was normal. \\
\hline & & A-02 & A & $06 / 03 / 93$ & & $7297: 01-25$ & $\begin{array}{l}\text { Tank condition was normal. } \\
\text { Stains and inarks on the ven- } \\
\text { tilation duct were caused by } \\
\text { water inleakage. The con- } \\
\text { ductivity probe was properly } \\
\text { deployed on the annulus } \\
\text { tlour. }\end{array}$ \\
\hline & & A-03 & A & $06 / 03 / 93$ & & $7298: 01-26$ & $\begin{array}{l}\text { Tank condition was normal } \\
\text { The conductivity prote was } \\
\text { properly deployed on the } \\
\text { annulus floor. }\end{array}$ \\
\hline & & A.04 & A & $06 / 03 / 93$ & & $7299: 01-25$ & $\begin{array}{l}\text { Tank condition was normal. } \\
\text { The conductivity prote was } \\
\text { properly deployed on the } \\
\text { annulus floor. }\end{array}$ \\
\hline & & P.01 & A & $0.5 / 11 / 93$ & $7288: 08$ & & Tank condition was normal. \\
\hline & & $\mathrm{P}-02$ & A & $05 / 11 / 93$ & 7288:04 & & Tank condition was norinal. \\
\hline & & P.03 & A & $0.5 / 11 / 93$ & $7288: 13$ & & Tank condition was normul. \\
\hline
\end{tabular}


Type of lnspection and Identificutlon Numbers

\begin{tabular}{|c|c|c|c|c|c|c|c|}
\hline Area & $\begin{array}{c}\text { Tunk } \\
\text { or } \\
\text { Ancillury }\end{array}$ & $\begin{array}{l}\text { Inspec: } \\
\text { tion } \\
\text { Port }\end{array}$ & $\begin{array}{c}\text { Annulus } \\
\text { or } \\
\text { Interior }\end{array}$ & Dute & WAP & PSP & Kemarks \\
\hline \multirow[t]{11}{*}{$\mathrm{H}$} & 48 & P. $(14$ & $A$ & $05 / 11 / 93$ & $7288: 12$ & & Tank condition was normal. \\
\hline & & P.0.5 & $A$ & $05 / 11 / 93$ & $7288: 11$ & & Tank conditions was normal \\
\hline & & P.06 & $A$ & $05 / 11 / 93$ & $7288: 10$ & & Tank conditions was normal \\
\hline & & P.07 & $\bar{A}$ & $(09 / 22 / 93$ & $7452: 01$ & & Tank cundilion was normal. \\
\hline & & P.(1)8 & $\mathrm{A}$ & $0.5 / 11 / 93$ & $7288: 01$ & & Tank condition was normal. \\
\hline & & P-OG & $A$ & $05 / 11 / 93$ & $7288:(12$ & & Tank condition was normal. \\
\hline & & $\mathrm{P}-10$ & $\mathrm{~A}$ & $0.5 / 11 / 93$ & $7288: 03$ & & Tunk condition was normal. \\
\hline & & P.11 & $\mathrm{A}$ & $0.5 / 11 / 93$ & $7288: 04$ & & Tunk condition was normal. \\
\hline & & P.12 & A & $0.5 / 11 / 93$ & $7288: 05$ & & Tank condition was normal. \\
\hline & & $\mathrm{P}-13$ & $A$ & $0.5 / 11 / 1) 3$ & 7288:(1)6 & & Tunk condition was normal. \\
\hline & & P.14 & A & $0.5 / 11 / 03$ & $7288: 07$ & & Tunk condition was normal. \\
\hline \multirow[t]{18}{*}{$\mathrm{H}$} & 49 & A.01 & A & $06 / 0.3 / 93$ & & $7.300: 01.25$ & Tank condition was normal. \\
\hline & & A-02 & $\bar{A}$ & $06 / 03 / 43$ & & $7.301: 01.25$ & $\begin{array}{l}\text { Tank condition was normal. } \\
\text { The conductivity probe was } \\
\text { properly deployed on the } \\
\text { annulus floor. }\end{array}$ \\
\hline & & A-03 & $\bar{A}$ & $06 / 03 / 93$ & & $7302: 01-24$ & $\begin{array}{l}\text { Tank condition was normal. } \\
\text { The conductivity prohe was } \\
\text { properly deployed on the } \\
\text { annulus floor. }\end{array}$ \\
\hline & & A-(14 & $\bar{A}$ & $06 / 03 / 93$ & & $7303: 01.25$ & $\begin{array}{l}\text { Tunk condition was normal. } \\
\text { The conductivity prothe was } \\
\text { properly deployed on the } \\
\text { annulus floor. }\end{array}$ \\
\hline & & P.01 & $\mathrm{A}$ & $0.5 / 03 / 93$ & 7270:01 & & Tank condition was normal. \\
\hline & & P.02 & $A$ & $05 / 03 / 93$ & 7270:02 & & Tank condition was normal. \\
\hline & & P-03 & $\mathrm{A}$ & $0.5 / 0.3 / 93$ & 7270:03 & & Tank condition was normal. \\
\hline & & P. 014 & $\mathrm{~A}$ & $0.5 / 0.3 / 93$ & $7270:(04$ & & Tank condition was normal. \\
\hline & & P.05 & $\bar{A}$ & $0.5 / 0.3 / 93$ & 727()$: 05$ & & $\begin{array}{l}\text { Stains observed on the tank } \\
\text { wall were caused by water } \\
\text { inleakage. No other change } \\
\text { was ohserved in the tank } \\
\text { condition. }\end{array}$ \\
\hline & & P-06 & $\mathrm{A}$ & $0.5 / 03 / 93$ & $7270: 06$ & & Tunk condition was normal. \\
\hline & & P. 07 & $\mathrm{~A}$ & $09 / 22 / 93$ & 7453:01 & & Tunk condition was normal. \\
\hline & & P.08 & A & $0.5 / 03 / 93$ & $7270: 08$ & & Tunk condition was normal. \\
\hline & & P.(0) & $\mathrm{A}$ & $0.5 / 0.3 / 93$ & 7270:09 & & Tunk condition was normal. \\
\hline & & P. 10 & $\mathbf{A}$ & $0.5 / 03 / 93$ & $7270: 10$ & & Tunk condition was normal. \\
\hline & & P.11 & $A$ & $05 / 03 / 93$ & $7270: 11$ & & Tunk condition was normal. \\
\hline & & P-12 & $\mathrm{A}$ & $0.5 / 0.3 / 93$ & $7270: 12$ & & Tunk condition was normal. \\
\hline & & P-13 & $\mathrm{A}$ & $0.5 / 03 / 93$ & $7270: 13$ & & Tank condition was normal. \\
\hline & & P-14 & $A$ & $0.5 / 0.3 / 93$ & $7270: 14$ & & Tank condition was normal. \\
\hline \multirow[t]{2}{*}{$\mathrm{H}$} & 50 & A.01 & $\mathrm{A}$ & $06 /(03 / 93$ & & $7304: 01-25$ & Tank condition was normal. \\
\hline & & A- $-(2)$ & A & $06 / 03 / 93$ & & $7305: 01-23$ & Tank condition was normal. \\
\hline
\end{tabular}


Type of Inspection and Identificution Numbers

\begin{tabular}{ccccccc}
$\begin{array}{c}\text { Area } \\
\text { or } \\
\text { Ancillary }\end{array}$ & $\begin{array}{c}\text { Inspec- } \\
\text { tlon } \\
\text { Port }\end{array}$ & $\begin{array}{c}\text { Annulus } \\
\text { or } \\
\text { Interior }\end{array}$ & Dute & WAP & DP & PSPP \\
\hline$H$ & 50 & A.0.3 & A & $0.5 /(0.3 / 93$ & $7283:(03-(14$ &
\end{tabular}

Stailis und marks on the tank wall wore cuused hy leakuge froin couling coil \#41. No other change was ohserved in the tank.

$\begin{array}{llll}\text { A.03 A } & 06 / 03 / 93 & 7306: 01.25 & \text { Chromate stuin on the tank }\end{array}$
wall was caused hy the fail. ure of couling wil 14 . The coil was identified ax a leaker on 0.5.03.93 and laken oul of service. No other chunge was observed in the cank. The conductivity probe was properly deployed on the unnulus flour.

\begin{tabular}{|c|c|c|c|}
\hline A. $(14$ & A $\quad(6 / 0) 3 / 43$ & $7307: 01-25$ & $\begin{array}{l}\text { Tink condilion was norinal. } \\
\text { The conductivity probe was } \\
\text { properly deployed on the } \\
\text { annulus floor. }\end{array}$ \\
\hline
\end{tabular}

\begin{tabular}{llll}
\hline P.01 & A & $01 / 20 / 93$ & $7175: 01$ \\
\hline P.02 & A & $01 / 20 / 93$ & $7175: 02$ \\
\hline P.03 & A & $01 / 20 / 93$ & $7175: 03$ \\
\hline P.04 & A & $01 / 20 / 93$ & $7175: 04$ \\
\hline P.05 & A & $01 / 20 / 93$ & $7175: 05$ \\
\hline P.05 & A & $05 / 03 / 93$ & $7238: 01.02$
\end{tabular}
Tunk condition was normal. Tank condition was normal. Tank condition was normal. Tank condition was normal. Tank condition was normal. Stuins and murks ubserved on the tunk wull were caused by leakage frum cooling coil *14. No other change was observed in the tank.

$\begin{array}{llll}\text { P.05 A } & \text { A } 05 /(0.3 / 93 & 72.39: 01-13 & \text { Inspection determined the }\end{array}$
liquid ohserved on the annulus floor was cooling water. Cooling coil \#14 was identified as the leaking coil.

\begin{tabular}{|c|c|c|c|c|c|c|}
\hline & & \multirow[b]{2}{*}{ Tank condition was normal. } \\
\hline & & P.06 & $A$ & $01 / 20 / 93$ & 7175:06 & \\
\hline & & P.07 & $\mathrm{A}$ & $01 / 20 / 93$ & 7175:07 & Tank condition was normal. \\
\hline & & P-08 & $\mathrm{A}$ & $05 / 11 / 93$ & 7290:01 & Tunk condition was normal. \\
\hline & & P. 04 & $\bar{A}$ & $01 / 2(1) / 93$ & $7175: 08$ & Tunk condition was normal. \\
\hline & & P. 10 & A & $01 / 20 / 93$ & $7175:(0)$ & Tank condition was normal. \\
\hline & & P.11 & $\Lambda$ & $01 / 20 / 93$ & $7175: 10$ & Tank condition was normal. \\
\hline & & P.12 & $\bar{A}$ & $01 / 20 / 93$ & $7175: 11$ & Tank condition was normal. \\
\hline & & P-13 & $\bar{A}$ & $01 / 29 / 93$ & $7175: 12$ & Tunk condition was normal. \\
\hline & & P.14 & $\mathrm{A}$ & $01 / 20 / 93$ & $7175: 13$ & Tank condition was normal. \\
\hline \multirow[t]{2}{*}{$\mathbf{H}$} & \multirow[t]{2}{*}{51} & A-01 & $\bar{A}$ & $06 / 0.3 / 93$ & $7308: 01-25$ & Tank condition was normal. \\
\hline & & A.02 & A & $(66 / 03 / 93$ & $7304: 01-25$ & $\begin{array}{l}\text { Tank condition was normal. } \\
\text { The conductivity probe was } \\
\text { properly deployed on the } \\
\text { annulus floor. }\end{array}$ \\
\hline
\end{tabular}


Type of Inspection and Identilicution Numbers

Tank Inspec- Annulus
Area or tion or
or Date WAP DP

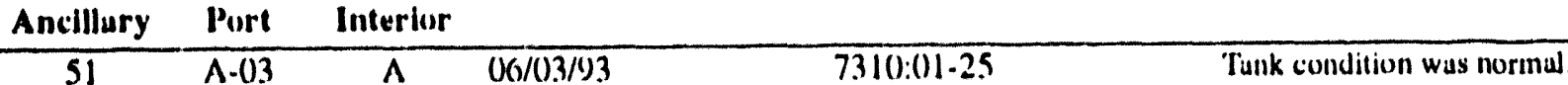

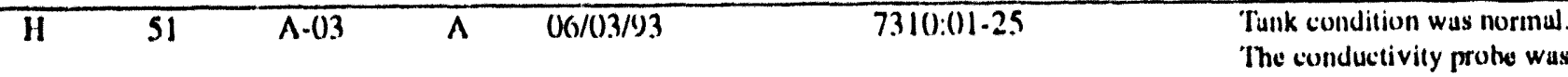
properly deployed on the annulus flour.

\begin{tabular}{|c|c|c|c|}
\hline A.04 & $(0) / 29 /(93$ & $7311: 01.23$ & $\begin{array}{l}\text { Tunk condition was normal } \\
\text { The conductivity probe was }\end{array}$ \\
\hline
\end{tabular}
properly deployed on the annulus floor.

\begin{tabular}{|c|c|c|c|c|}
\hline P.01 & A & $05 / 11 / 43$ & $7280: 01$ & Tank condition was normal \\
\hline P.(22 & $\mathrm{A}$ & $0.5 / 11 / 43$ & $7289: 02$ & Tunk condition was normal \\
\hline P. 0.3 & $\mathbf{A}$ & $(16 / 03 / 93$ & $7280: 03$ & Tunk condition was normal \\
\hline P. 04 & A & $05 / 11 / / 3$ & 7280:04 & Tank condition was normal \\
\hline P. 0.5 & $\mathbf{A}$ & $05 / 11 / 93$ & $7289: 05$ & Tunk condition was normal \\
\hline P.116 & A & $05 / 11 / / 3$ & $7284:(16$ & Tunk condition was normal \\
\hline P.07 & $\bar{A}$ & $(x) / 22 / 93$ & $74.54: 01$ & Tank condition was normal \\
\hline
\end{tabular}
Stains and marks observed on the ventilation duct were caused by water inleakage.

\begin{tabular}{|c|c|c|c|c|}
\hline P.08 & A & $0.5 / 11 / 13$ & $7280: 07$ & Tank condition was normal. \\
\hline P.(W) & $\bar{A}$ & $0.5 / 11 / 93$ & $7289: 08$ & Tunk condition was normal. \\
\hline P.10 & $\bar{A}$ & $0.5 / 11 / 93$ & $7284:(04)$ & Tank condition was normal. \\
\hline P.11 & A & $0.5 / 11 / 43$ & $7284: 10$ & Tank condition was normal. \\
\hline P.12 & $A$ & $0.5 / 11 / 93$ & $7289: 11$ & Tunk condition was normal. \\
\hline $\bar{P}-13$ & $\overline{\mathrm{A}}$ & $0.5 / 11 / 93$ & $7289: 12$ & Tunk condition was normal. \\
\hline P.14 & $\bar{A}$ & $05 / 11 / 93$ & $7289: 13$ & Tunk condition was normal. \\
\hline B-03 & 1 & $10 / 28 / 93$ & & CCTV was used to docu- \\
\hline
\end{tabular}
munt surfuce velocity of the waste while operating the pumps installed in risers B-4 and $H$. (Documented on File Tape \#2(0).

\begin{tabular}{llll}
\hline B-0.3 & $11 / 22 / 93$ & $\begin{array}{l}\text { CCTV was used to index the } \\
\text { discharge from the slurry } \\
\text { puinps installed in the B-04 } \\
\text { and HI risers. }\end{array}$ \\
\hline E-01 & I & $09 / 11 / 9) 3$ & $\begin{array}{l}\text { CCIV was used to search } \\
\text { for a bearing walter leak in } \\
\text { the slurry pump installed in } \\
\text { the B-1 riser. The source of } \\
\text { the leak was not determined. } \\
\text { Surface velocity of the waste } \\
\text { during slurry pump opera- } \\
\text { tiun was documented on File } \\
\text { Tape \#254. }\end{array}$ \\
\hline
\end{tabular}


Type of Inspection and Identificution Numloers

\begin{tabular}{|c|c|c|c|c|c|c|c|c|}
\hline Area & $\begin{array}{c}\text { Tank } \\
\text { or } \\
\text { Ancillary }\end{array}$ & $\begin{array}{l}\text { Inspec- } \\
\text { tion } \\
\text { Port }\end{array}$ & $\begin{array}{l}\text { Annulus } \\
\text { or } \\
\text { Interior }\end{array}$ & Dute & WAP & DP & PSIP & Kemurks \\
\hline
\end{tabular}
ineill surface velocity of the waste while operating the pump installed in the $\mathrm{G}$ riser. (Decumented on File Tupe \#2(0)).

$\begin{array}{lll}E \cdot 01 & 1 & 11 / 22 / 93\end{array}$

CCTV was used to index the discharge from the slurry pumps instulled in the B-01 and $\mathrm{G}$ risers.

H CTS $12 / 22 / 93$

CCIV was used to assist III.WO in the removal and installation of a jumper at the HCTS pit. The replaceineitt of jumper 23/24-10A was made due to a failed gusket at the automatic valve. A video overview showing equipment configuration in the pit was documented un File Tape \#26.5.

SE $\quad 12 / 18 / 93$
CCIV was used to identify the source of leakage in the CTS pit. The jumper from Wall nozzles 23-24-10A to the draw off pump was ohserved leaking at the autoinalic valve. The leakuge was due to a failed gasket. The jumper was replaced on 12-22-93. The inspection was documented on File Tupe 265.

$\begin{array}{lll}\text { F DB6 } & 03 / 02 / 93\end{array}$
CCTV inspection was made to search for the source of water leaking into LDB2 at DB6. Source of inleakage was not determined. The inspection was documented un File Tupe \#242.

$04 /(16 / 93$ CCTV inspection was made to seurch for the source of water leaking into LDB2 at DBG. Source of inleakage was not determined. The inspection was documented on File Tape \#242.

$\begin{array}{lll}\text { H DB7 } & \text { 04/07/93 }\end{array}$

Visual inspection verified juinper 22 to $5 \mathrm{E}$ was stored on the floor of the pit beneuth the SW riser. 
Type of Inspection and Identificution Numbers

\begin{tabular}{|c|c|c|c|c|c|c|c|}
\hline Area & $\begin{array}{c}\text { Tunk } \\
\text { or } \\
\text { Ancillary }\end{array}$ & $\begin{array}{l}\text { Inspec:- } \\
\text { tlun } \\
\text { Port }\end{array}$ & $\begin{array}{c}\text { Annulus } \\
\text { or } \\
\text { Interior }\end{array}$ & Dute & WAP & DI & PSP \\
\hline H & DB7 & & & & & & \\
\hline
\end{tabular}

CCTV was used to docu. inent the contiguration of HDB7 after jumper 22 to 5E was replaced. The configura. tion was documented on File lape $\$ 247$.

H EVAPI $05 / 26 / 93$

CCIV was used tu document conditions in the vent vaull at the $1 \mathrm{H}$ evaporator. $A$ pool of liquid was observed at the north end of the vault. Other areas had dried since last inspected on 03.04-92. The inspection was docu. mented un File Tape $\$ 249$. CCIV was used to docuinent conditions in the $\mathbf{~} \mathrm{H}$ evaporator cell. No unusual cundition was observed. The inspection was documented on File Tupe $\mathbf{2 5 8}$.

F EVAP2 SE $11 / 11 / 93$

CCTV was used to document conditions in the $2 F$ evaporator cell. No unusual condition was found. The inspection was documented on File Tupe $\$ 2.58$.

\begin{tabular}{llll}
\hline EVAP2 & SW & $11 / 01 / 93$
\end{tabular}

CC'TV was used to document conditions in the $2 H$ evapurator cell. Condition of the cell, evaporator pot and jumpers appeared normal. A suhstance observed on the cell fluor uppeared to be mercury. Droplets and small pouls of the substance as large as 2 inches in diameter were observed. The inspection was docunented on File Tupe \#258.

\begin{tabular}{llll}
\hline F & PPI & SW & $07 / 01 / 93$
\end{tabular}

CCIV was used to docaineit the quantity of dehris in the sump. Inspection revealed the stuinless steel pit liner was distended severul inches from the concrete wall. The liner on hoth walls alouve the sump were distended. 
Type of Inspection and Identilication Numbers

\begin{tabular}{|c|c|c|c|c|c|c|c|c|}
\hline Area & $\begin{array}{c}\text { Tank } \\
\text { or } \\
\text { Ancillary }\end{array}$ & $\begin{array}{l}\text { Inspec- } \\
\text { tion } \\
\text { Port }\end{array}$ & $\begin{array}{l}\text { Annulus } \\
\text { or } \\
\text { Interior }\end{array}$ & Dute & WAP & DI & PSP & Remarks \\
\hline $\mathbf{F}$ & PPl & SW & & $11 / 18 / 93$ & & & & $\begin{array}{l}\text { CCIV was used to docu- } \\
\text { ment conditions in PP1. The } \\
\text { vessel floor was cluttered } \\
\text { with hoses. Otherwise, con- } \\
\text { ditions were norinal. The } \\
\text { inspection was documented } \\
\text { on File Tape \#262. }\end{array}$ \\
\hline $\mathbf{F}$ & PP2 & & & $10 / 01 / 93$ & & & & $\begin{array}{l}\text { CCTV was used to observe } \\
18 \text { and } 21 \text { for leakage. Nei- } \\
\text { ther valve leaked when } \\
\text { stean was introduced. }\end{array}$ \\
\hline$F$ & SSMH & & & $12 / 30 / 93$ & & & & $\begin{array}{l}\text { CCTV was used to docu- } \\
\text { ment conditions in the man- } \\
\text { hole lociated west of the hole } \\
\text { created by a collapsed sub- } \\
\text { surface void near Tank } 28 \text {. } \\
\text { The sewer lines viewable } \\
\text { from the manhole were also } \\
\text { inspected. Silt, mud and } \\
\text { deliris approximately } 5 " \\
\text { deep was observed in the } \\
\text { sewer lines. No other anom- } \\
\text { alies were observed in the } \\
\text { manhole. }\end{array}$ \\
\hline $\bar{F}$ & SSMH & & & $12 / 30 / 93$ & & & & $\begin{array}{l}\text { CCTV was used to docu- } \\
\text { ment conditions in the man- } \\
\text { hole located east of the bole } \\
\text { created by a collapsed sub- } \\
\text { surface void near Tank } 28 \text {. } \\
\text { The sewer lines viewable } \\
\text { from the manhole was also } \\
\text { inspected. Silt, mud and } \\
\text { debris approximutely 5" } \\
\text { deep was observed in the } \\
\text { sewer lines. Erosion of the } \\
\text { brick and concrete liner was } \\
\text { observed. }\end{array}$ \\
\hline $\mathbf{F}$ & WLE & $2 F$ & & $12 / 07 / 93$ & & & $7474: 01-72$ & Normal \\
\hline $\mathrm{H}$ & WLE & $2 \mathrm{H}$ & & $12 / 06 / 93$ & & & $7477: 01-72$ & Norinal \\
\hline$F$ & WLE & $5 \mathrm{~F}$ & & $11 / 12 / 93$ & & & $7468: 01-19$ & $\begin{array}{l}\text { Concrete encusement cover } \\
\text { C-01 (Drawing W147709) } \\
\text { adjucent to FDB } 1 \text { had } \\
\text { cracked and slumped down- } \\
\text { ward a few inches. }\end{array}$ \\
\hline $\mathbf{H}$ & WLE & $5 H$ & & $11 / 03 / 93$ & & & $7463: 01-24$ & $\begin{array}{l}\text { Encusement structural con- } \\
\text { dition was normal. Conden- } \\
\text { sation was ohserved on the } \\
\text { holtom of enciasement cov- } \\
\text { ers. }\end{array}$ \\
\hline
\end{tabular}


Type of Inspection and Identification Numbers

\begin{tabular}{|c|c|c|c|c|c|c|c|c|}
\hline Area & $\begin{array}{c}\text { Tank } \\
\text { or } \\
\text { Ancillary }\end{array}$ & $\begin{array}{l}\text { Inspec- } \\
\text { tion } \\
\text { Port }\end{array}$ & $\begin{array}{c}\text { Annulus } \\
\text { or } \\
\text { Interior }\end{array}$ & Date & WAP' & DP & P'SP & Remarks \\
\hline $\bar{F}$ & WLE & $6 \Gamma$ & & $11 / 18 / 93$ & & & $747(0): 01-36$ & $\begin{array}{l}\text { Rust stuined areas observed } \\
\text { on the bottom surface of the } \\
\text { C-16 (Drawing W147709) } \\
\text { encassement cover suggest } \\
\text { that the rebar has corroded. } \\
\text { Hairline cracks and a void } \\
\text { possilly caused by spalling } \\
\text { were observed on the hottom } \\
\text { surface of the concrete } \\
\text { cover. }\end{array}$ \\
\hline \multirow[t]{2}{*}{$\mathbf{H}$} & WLE & $6 \mathrm{H}$ & & $11 / 16 / 93$ & & & $7469: 01-25$ & $\begin{array}{l}\text { Enciasement structural con- } \\
\text { dition was normal. Conden- } \\
\text { sation was observed on the } \\
\text { bottom of encasement cov- } \\
\text { ers. }\end{array}$ \\
\hline & & $7 \mathrm{H}$ & & $11 / 17 / 93$ & & & $7473: 01-53$ & $\begin{array}{l}\text { Encusement structural con- } \\
\text { dition was normal. Stains } \\
\text { and marks observed on the } \\
\text { enciasement side walls were } \\
\text { caused by water inleakage. } \\
\text { Water was observed on the } \\
\text { encusement floor. }\end{array}$ \\
\hline
\end{tabular}

Note: The numbers listed under WAP, DP, and PSP identify pholographs in the HLWE files.

WAP = wide angle photography: $D P=$ direct photography; $P S P=$ periscopic photography; $B=$ diversion hox; WLE = waste line encasement; $E V A P=$ evapurator; $C$ 'IS = concentrale transfor system; LDB = leak detection box; $P P=$ pump pit; $S S M H=$ storm sewer manhole. 
This page intentionally left blank. 

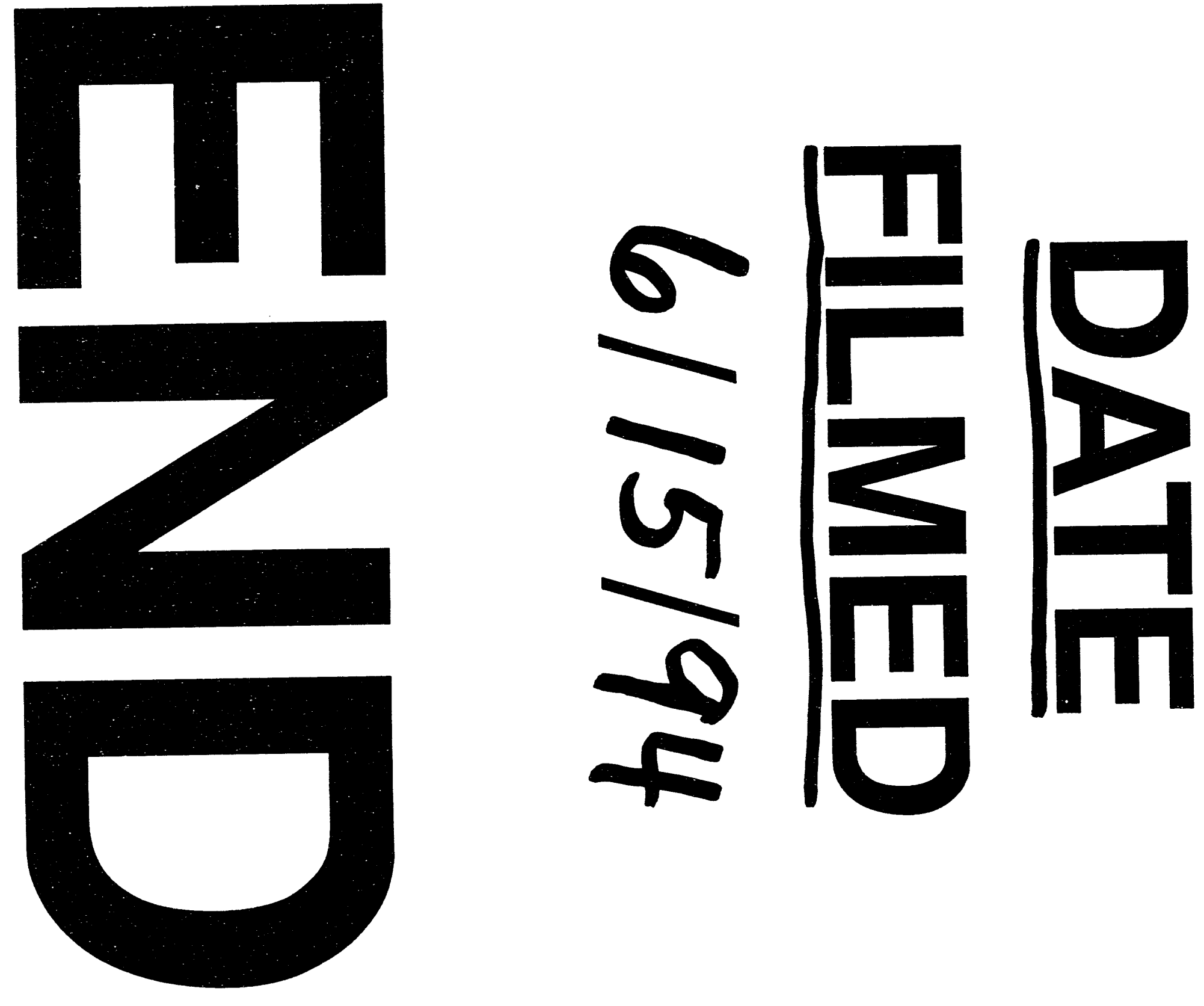
